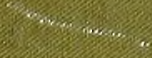

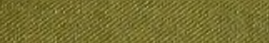

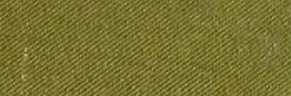

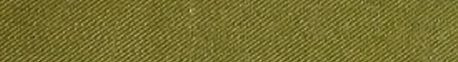

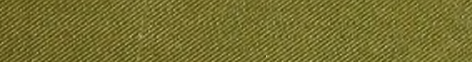

更

1010

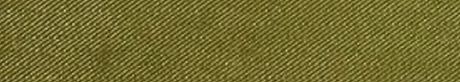

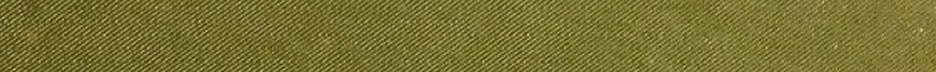

(1)

1

1)

1

,

1

1

索

1

(1)

1

1

1

政

1

1

倠

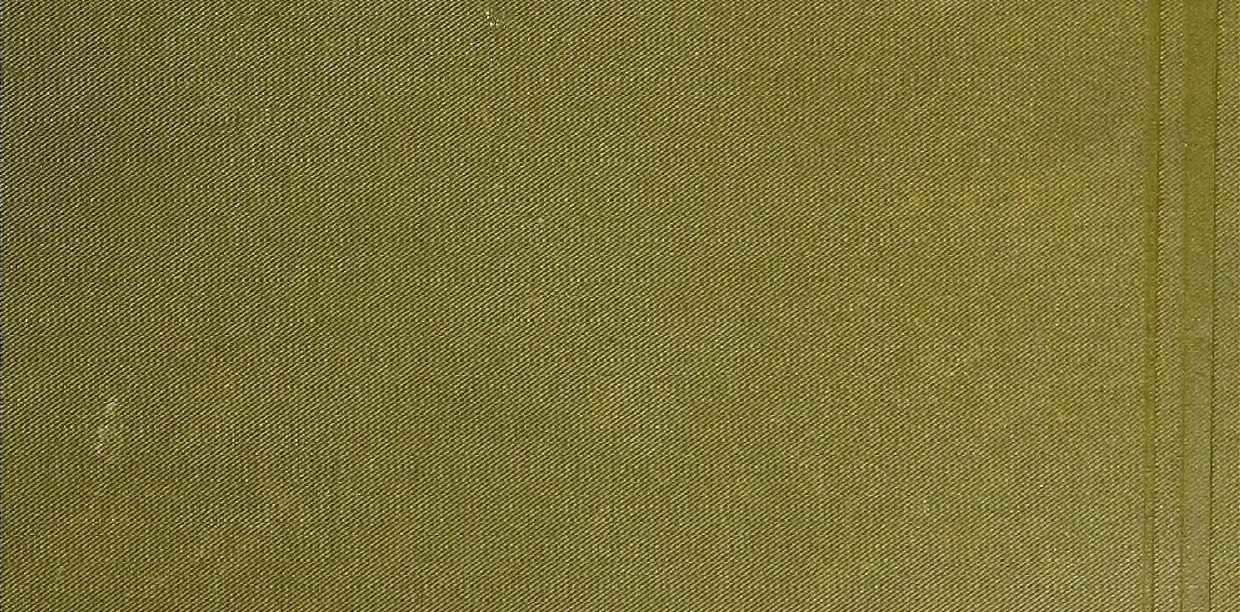




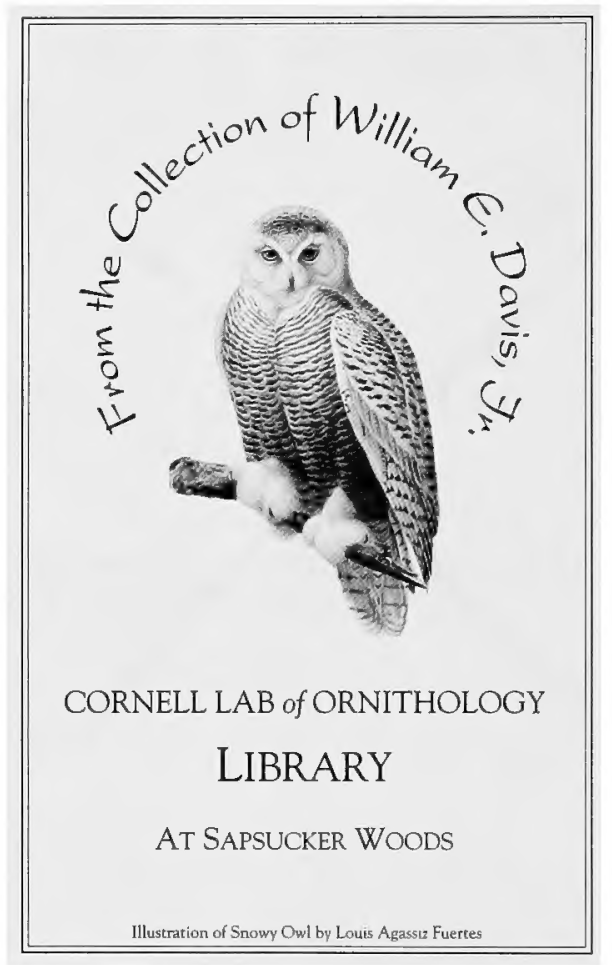


ORPELL UNVERSITY LRRAAY

31924090288

$\underline{0} 288790$

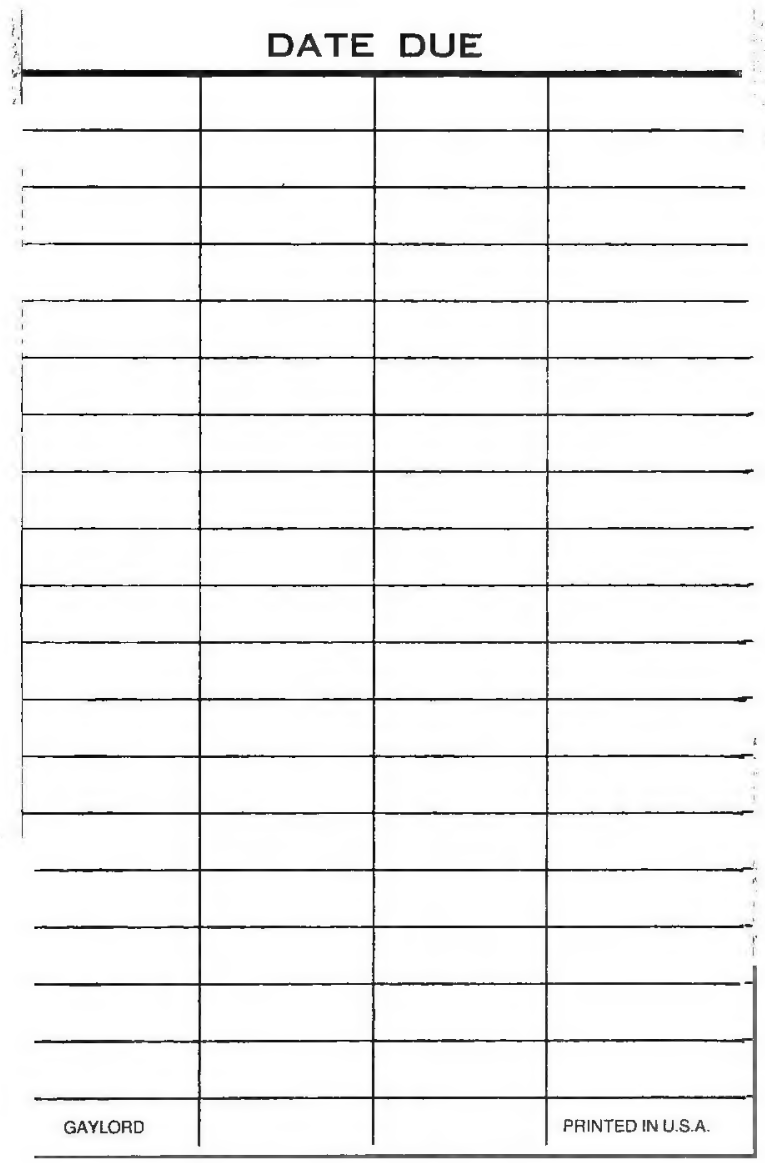




$$
\text { , }
$$$$
\text { • }
$$$$
-
$$ 


\title{
THE BIRDS OF
}

\section{NEW JERSEY.}

\author{
COMPILED BY \\ CHARLES A. SHRINER, \\ STATE FISH AND GAME PROTECTOR.
}

BY AUTHORITY OF THE

FISH AND GAME COMMISSION

OF THE STATE OF NEW JERSEY.

PRINTED FOR THE COMMISSION.

1896. 


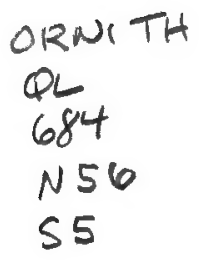

COPYRIGHT, 1896, $\mathbf{B Y}$

CHARLES A. SHRINER.

$$
80187
$$




\section{THE COMMISSION :}

GEORGE PFEIFFER, Jr., President.

HOWARD P. FROTHINGHAM, Secretary and Treasurer.

PARKER W. PAGE. 


\section{Cornell University Library}

The original of this book is in the Cornell University Library.

There are no known copyright restrictions in the United States on the use of the text. 


\section{INTRODUCTION.}

The object of this work is the familiarizing of the every day citizen unused to scientific terms, with the habits and economic importance of the birds of the State of New Jersey. The study of Ornithology as suggested in books treating on the subject is one attended with difficulties sufficient to dampen the ardor of even the more than willing student. The long and high-sounding names used in the scientific nomenclature-which even Latinizes common English words - the many divisions into families and species, and the disputes of authors as to what particular family a certain bird belongs to have undoubtedly in the past deterred many from following a study in itself so interesting and so useful. In the present treatise the author has avoided all scientific terms and designations and has endeavored to foster a better acquaintance between the human family and its feathered friends without necessitating the medium of protracted study on the part of those who would like to know more about the birds around us. For the advanced student this book will be of no value, for in it will be found no learned disquisitions pertaining to the higher phases of Ornithology; it simply purports to tell in plain language sufficient about the habits of birds to indicate their value to mankind and by plain descriptions to facilitate identification. The bobolink, with its variable plumage and merry song, is an object of interest, but that interest will be minimized to a great many when they are told that the first thing of importance to know about the bobolink is that he is a dolichonyx oryzvorus of the family of icteridae. Scientific classification has its manifold uses, but there is something so deterrent about it to the average reader that it has been wholly eschewed in the present publication. 
A knowledge of the value of birds can be obtained without it.

The number of birds in New Jersey, which either remain here all the year or whose visits are more or less prolonged during certain seasons, is very large and a comprehensive treatise on all of them would make a ponderous volume. The endeavor of the author in the present work has been to deal with them in accordance with their importance; the transient visitor who merely straggles into the state from adjoining territory or who remains only long enough to secure rest and food to supply strength for further travel, has not been considered worthy of the attention to be devoted to him who remains with us at all seasons or whose sojourn is long enough to awaken in us either an interest in his habits or a desire for his return.

Few facts hitherto unpublished will be found in this volume. The study of American Ornithology dates back to almost the date of the discovery of this continent and ever since that time have admirers of nature studied the habits of our birds. The foundation was laid by Alexander Wilson and he has been followed by hundreds, each of whom has contributed his quota, either large or small, until the structure of American Ornithology was brought to its present state of almost completion. The work of Wilson has been used as the foundation for the present treatise, supplemented by the works of Witmer Stone, Frank M. Chapman, D. G. Elliott and others. The main facts in relation to the breeding location and range have been taken from Mr. Witmer Stone's "Birds of Eastern Pennsylvania and New Jersey." The author is also indebted to Mr. Stone for a painstaking revision of this work before it went to press.

The Delaware Valley Ornithological Club is an organization the members of which have devoted a great deal of time and study to the birds of New Jersey as well as of Pennsylvania. This club meets in the building of the Academy of Natural Sciences in Philadelphia and the 
members are ever ready to assist the seeker after knowledge by identifying specimens or replying to queries. Letters may be addressed to Mr. Witmer Stone, care of the Academy of Natural Sciences, Philadelphia.

Paterson, N. J., December 1, 1896. 


\section{BIRD DAY IN THE SCHOOLS.}

The following is a copy of a circular issued in July last by the Division of Biological Survey of the United States Department of Agriculture:

The observance of Arbor Day by the schools has been so successful that it has been suggested that a Bird Day, to be devoted to instructing the children in the value of our native birds and the best means of protecting them, might with propriety be added to the school calendar. The idea of setting apart one day in the year for the planting of trees was first suggested nearly twenty-five years ago by the Hon. J. Sterling Morton, now Secretary of Agriculture. More than a million trees were planted on the first Arbor Day, and the importance of the day has gradually increased until it has come to be observed in nearly every State and Territory in the Union. One of the greatest benefits of Arbor Day is the sentiment and interest aroused in the subject of trees and in the broader study of nature. It is believed that the observance of a Bird Day would appeal to our people-particularly our youth—even more strongly.

\section{HISTORY OF BIRD DAY.}

Bird Day is more than a suggestion. It has been already adopted in at least two cities with marked success, but as yet it is still an experiment. Apparently the idea originated with Prof. C. A. Babcock, superintendent of schools in Oil City, Pa., who wrote to the Department of Agriculture in 1894 urging the establishment of such a day, and stating that May 4 would be observed as Bird Day in Oil City. In reply, the Secretary of Agriculture sent the following letter : 
Washington, D. O., April 23, 1894.

MR. C. A. BABCOCK,

Superintendent of Schools, Oil City, Pa.

DeAR SIR: Your proposition to establish a "Bird Day" on the same general plan as "Arbor Day" has my cordial approval.

Such a movement can hardly fail to promote the development of a healthy public sentiment toward our native birds, favoring their preservation and increase. If directed toward this end, and not to the encouragement of the importation of foreign species, it is sure to meet the approval of the American people.

It is a melancholy fact that among the enemies of our birds two of the most destructive and relentless are our women and our boys. The love of feather ornamentation so heartlessly persisted in by thousands of women, and the mania for collecting eggs and killing birds so deeply rooted in our boys, are legacies of barbarism inherited from our savage ancestry. The number of beautiful and useful birds annually slaughtered for bonnet trimmings runs up into the hundreds of thousands and threatens, if it has not already accomplished, the extermination of some of the rarer species. The insidious egg-hunting and pea-shooting proclivities of the small boy are hardly less widespread and destructive. It matters little which of the two agencies is the more fatal since neither is productive of any good. One looks to the gratification of a shallow vanity, the other to the gratification of a cruel instinct and an expenditure of boyish energy that might be profitably diverted into other channels. The eril is one against which legislation can be only palliative and of local efficiency. Public sentiment, on the other hand, if properly fostered in the schools, would gain force with the growth and development of our boys and girls and would become a hundredfold more potent than any law enacted by the State or Congress. I believe such a sentiment can be developed, so strong and so universal, that a respectable woman will be ashamed to be seen with the wing of a wild bird on her bonnet, and an honest boy will be ashamed to own that he ever robbed a nest or wantonly took the life of a bird.

Birds are of inestimable value to mankind. Without their unremitting services our gardens and fields would 
be laid waste by insect pests. But we owe them a greater debt even than this, for the study of birds tends to develop some of the best attributes and impulses of our natures. Among them we find examples of generosity, unselfish devotion of the love of mother for offspring and other estimable qualities. Their industry, patience, and ingenuity excite our admiration; their songs inspire us with a love of music and poetry; their beautiful plumages and graceful manners appeal to our esthetic sense; their long migrations to distant lands stimulate our imaginations and tempt us to inquire into the causes of these periodic movements, and finally, the endless modifications of form and habits by which they are enabled to live under most diverse conditions of food and climate-on land and at sea-invite the student of nature into inexhaustible fields of pleasurable research.

The cause of bird protection is one that appeals to the best side of our natures. Let us yield to the appeal. Let us have a Bird Day-a day set apart from all the other days of the year to tell the children about the birds. But we must not stop here. We should strive continually to develop and intensify the sentiment of bird protection, not alone for the sake of preserving the birds, but also for the sake of replacing as far as possible the barbaricimpulses inherent in child nature by the nobler impulses and aspirations that should characterize advanced civilization.

Respectfully,

J. STERLING MoRTON, Secretary of Agriculture.

Of the success of this first experiment there can be no question. "The day was observed in the Oil City schools with a degree of enthusiasm which was good to see. The amount of information about birds that was collected by the children was simply amazing. Original compositions were read, informal discussions were held, talks by teachers were given, and the birds in literature were not forgotten or overlooked. * * * The idea simply needs to be known to meet with a warm welcome akin to that with which we greet our first robin or song sparrow in the spring."-(Journal of Education, May 24, 1894.)

Bird Day was observed in 1895 and again on May 8, 1896 , with such success that it bids fair to become a regular 
feature of the schools in Oil City at least. In speaking of the third anniversary, Superintendent Babcock says :

The exercises this year (1896), as upon previous ones, varied somewhat in the different grades. They consisted of original compositions by the pupils, containing the results of their observations of birds, of talks by pupils and teachers, comparing observations, giving localities of bird haunts, and general exchange of bird lore; of recitations from eminent prose writers on birds, and from the poets; finally many of our schools closed their exercises by a trip to the woods to listen to the vesper concert of our feathered brothers. *** We begin the study of birds on January 1 and continue till June, studying those that stay all winter and trying to keep account of the new comers as they arrive. We devote two periods of twenty minutes each per week to this study. Bird Day is a summary or focusing of the work of the year. *** The results of bird study and of Bird Day are interesting. Our children generally know most of our bird residents, they also love them, and feel like protecting them. There has been a complete change in relations existing between the small boy and the birds.

Other suggestions regarding the study of birds and the observance of the day will be found in two interesting articles on Bird Day, one by Superintendent Babcock, in the Journal of Education for April 4, 1895; the other by A. E. Winship, in the Outlook for April 6, 1895, p. 560 .

Last spring (1896) the movement was started in Iowa by Prof. C. H. Morrill, superintendent of schools at Fort Madison, who was apparently unaware of the experiment in Pennsylvania. He set apart May 29, 1896, as Bird Day in the schools under his jurisdiction, and describes the result as follows:

I never saw children more enthusiastic in preparation or happier in rendering. They brought their pet birds, they decorated the rooms with flowers and green branches, they ornamented the boards with drawings of birds, birds' nests, flowers, etc. * * * The buildings rang with bird music all day, the children were happier than ever before and visitors came until standing space in 
many rooms was at a premium. * * * It is safe to say that we shall celebrate the day next year. I hope it may come to be a national day.

The Department has also received inquiries concerning Bird Day from Connecticut, and the matter is attracting attention in Nebraska. Professor Lawrence Bruner in his "Notes on the Birds of Nebraska," published in May, 1896, says:

It might be well to suggest that the subject (of Ornithology) is of sufficient importance to call for its being taught in our public schools, to a limited extent at least. We should have a "Bird Day" just as we have an "Arbor Day" and a "Flag Day," when suitable exercises should be held commemorative of the occasion.

\section{OBJECT OF BIRD DAY.}

From all sides come reports of a decrease in native birds due to the clearing of the forests, draining of the swamps and cultivation of land, but especially to the increasing slaughter of the birds for game, the demand for feathers to supply the millinery trade, and the breaking up of nests to gratify the egg-collecting proclivities of small boys. An attempt has been made to restrict these latter causes by legislation. Nearly every State and Territory has passed game laws, and several States have statutes protecting insectivorous birds. Such laws are frequently changed and cannot be expected to accomplish much unless supported by popular sentiment in favor of. bird protection. This object can only be attained by demonstrating to the people the value of birds, and how can it be accomplished better than through the medium of the schools?

Briefly stated, the object of Bird Day is to diffuse knowledge concerning our native birds and to arouse a more general interest in bird protection. As such it should appeal not only to ornithologists, sportsmen and farmers, who have a practical interest in the preservation 
of birds, but also to the general public, who would soon appreciate the loss if the common songsters were exterminated.

It is time to give more intelligent attention to the birds and appreciate their value. Many schools already have courses in natural history or nature study and such a day would add zest to the regular studies, encourage the pupils to observe carefully, and give them something to look forward to and work for. In the words of the originator of the day, "the general observance of a Bird Day in our schools would probably do more to open thousands of young minds to the reception of bird lore than anything else that can de devised." The first thing is to interest the scholars in birds in general and particularly in those of their own locality. Good lists of birds have been prepared for several of the States, and popular books and articles on ornithology are within the reach of every one. But the instruction should not be limited to books; the children should be encouraged to observe the birds in the field, to study their habits and migrations, their nests and food, and should be taught to respect the laws protecting game and song birds.

\section{VALUE OF BIRD DAY.}

When the question of introducing Arbor Day into the schools was brought before the National Educational Association in February, 1884, the objection was made that the subject was out of place in the schools. The value of the innovation could not be appreciated by those who did not see the practical bearing of the subject on an ordinary school course. But at the next meeting of the Association the question was again brought up and unanimously adopted-to the mutual benefit of the schools and of practical forestry. With the advent of more progressive ideas concerning education there is a demand for instruction in subjects which a few years ago would have been con- 
sidered out of place, or of no special value. If the main object of our educational system is to prepare boys and girls for the intelligent performance of the duties and labors of life, why should not some attention be given to the study of nature, particularly in rural schools where the farmers of the next generation are now being educated?

The study of birds may be taken up in several ways and for different purposes; it may be made to furnish simply a course in mental training or to assist the pupil in acquiring habits of accurate observation; it may be taken up alone or combined with composition, drawing, geography. or literature. But it has also an economic side which may appeal to those who demand purely practical studies in schools. Economic ornithology has been defined as the "study of birds from the standpoint of dollars and cents." It treats of the direct relations of birds to man, showing which species are beneficial and which injurious, teaching the agriculturist how to protect his feathered friends and guard against the attacks of his foes. This is a subject in which we are only just beginning to acquire exact knowledge, but it is none the less deserving of a place in our educational system on this account. Its practical value is recognized both by individual States and by the national government, which appropriate considerable sums of money for investigations of value to agriculture. Much good work has been done by some of the experiment stations and State boards of agriculture, particularly in Illinois, Indiana, Massachusetts, Michigan, Nebraska and Pennsylvania. In the United States Department of Agriculture, the Division of Biological Survey (formerly the Division of Ornithology) devotes much attention to the collection of data respecting the geographic distribution, migration, and food of birds, and to the publication and diffusion of information concerning species which are beneficial or injurious to agriculture. Some of the results of these investigations are of general 
interest, and could be used in courses of instruction in even the lower schools. Such facts would thus reach a larger number of persons than is now possible, and would be made more generally available to those interested in them.

If illustrations of the practical value of a knowledge of zoology are necessary they can easily be given. It has been estimated recently that the forests and streams of Maine are worth more than its agricultural resources. If this is so, is it not equally as important to teach the best means of preserving the timber, the game and the fish, as it is to teach students how to develop the agricultural wealth of the State? In 1885 Pennsylvania passed its famous "scalp act," and in less than two years expended between $\$ 75,000$ and $\$ 100,000$ in an attempt to rid the State of animals and birds supposed to be injurious. A large part of the money was spent for killing hawks and owls, most of which belonged to species which were afterwards shown to be actually beneficial. Not only was money thrown away in a useless war against noxious animals, but the State actually paid for the destruction of birds of inestimable value to its farmers. During the last five or six years two States have been engaged in an unsuccessful attempt to exterminate English sparrows by paying bounties for their heads. Michigan aud Illinois have each spent more than $\$ 50,000$, but, although millions of sparrows have been killed, the decrease in numbers is hardly perceptible. A more general knowledge of the habits of the English sparrow at the time the bird was first introduced into the United States would not only have saved this outlay of over $\$ 100,000$, but would also have saved many other States from loss due to depredations by sparrows.

Is it not worth while to do something to protect the birds and prevent their destruction before it is too late? A powerful influence for good can be exerted by the schools if the teachers will only interest themselves in the 
movement, and the benefit that will result to the pupils could hardly be attained in any other way at so small an expenditure of time. If it is deemed unwise to establish another holiday, or it may seem too much to devote one day in the year to the study of birds, the exercises of Bird Day might be combined with those of Arbor Day.

It is believed that Bird Day can be adopted with profit by schools of all grades, and the subject is recommended to the thoughtful attention of teachers and school superinteudents throughout the country, in the hope that they will co-operate with other agencies now at work to prevent the destruction of our native birds.

\section{T. S. PALMER,}

Approved: Acting Chief of Division.

Chas. W. Dabnex, Jr.,

Washington, D. C., July 2, 1896. 


\section{ILLUSTRATIONS.}

The illustrations in this publication were made from specineus mounted for that purpose by Mr. Andrew Booth, of Paterson, with the exception of those representing Cooper's Hawk, Sharp-shinned Hawk, Cuckoo, Chipping Sparrow and Song Sparrow, Chewink, Wood Thrush, Catbird, Meadowlark, Barn Swallows, Kingbird, Cardinal Bird, Screech Owl, Barred Owl, Red-tailed Hawk, Woodpeckers and Kingfishers, which were made from specimens in the American Museum of Natural History in New York city. 


\section{MIGRATION OF BIRDS.}

[From Mr. Witmer Stone's "Birds of Eastern Pennsylvania and New Jersey."]

The spring migration in the vicinity of Philadelphia begins early in February with the arrival from farther south of scattered bunches of Robins, Bluebirds, Purple Grackles, and a few other species which often occur in small numbers during the winter.

About the middle of the month, on the first clear, spring-like day when the temperature rises to 60 or 70 degrees F., a well marked wave takes place. Purple Grackles, Red-winged Blackbirds, Robins, Bluebirds and a few Flickers are the principal species, the Grackles being the most numerous. The greater part of these early migrants seem to pass farther north.

From the time of occurrence of the first well marked wave, the species above mentioned continue to pass in increasing numbers during favorable weather, but there is usually no other decided wave until about the middle of March.

During this month, in addition to the species already mentioned, the principal migrants are the Meadowlark, Pewee, Field Sparrow, Fox Sparrow, Cowbird, Dove, Canada Goose and Killdeer Plover, together with a few Yellow-bellied Sapsuckers, Savanna Sparrows, Vesper Sparrows, Myrtle Warblers and Rusty Grackles. None of these birds, however, arrive-at least in abundancebefore the middle of the month.

Up to April 1 no migrants have been recorded in the records that we have examined which do not occur occasionally in winter, either at Philadelphia or a little farther south in New Jersey, except the Canada Goose and Chipping Sparrow, which latter species has been once or twice noticed during the last week of March. 
After the first of April, however, the strictly summer species and transients begin to arrive. There are generally several well marked waves during the month, their most characteristic species being the Hermit Thrush, Ruby-crowned Kinglet, Chipping Sparrow. Chimney Swift, Barn Swallow, Bank Swallow, Myrtle Warbler, House Wren, Thrasher, Chewink, Black and White Warbler, Maryland Yellow-throat and Solitary Vireo.

A number of other species sometimes arrive during the last week in April, when there often occurs a wave which seems to be a forerunuer of the great "Thrush and Warbler waves" of May, which brings the first stragglers of many species which are really characteristic of the latter month.

The following list includes such species as have been noted-generally in smaller numbers-from April 20 to 30 in the vicinity of Philadelpliia, but which do not arrive in force until May:

Kingbird,

Crested Flycatcher,

Orchard Oriole,

Scarlet Tanager,

Red-eyed Vireo,

Yellow Warbler,
Black-throated Green Warbler, Parula Warbler,

Water Thrush,

Catbird,

Wilson's Thrush,

Wood Thrush.

About the first of May the species just mentioned, together with many Warblers, etc., arrive in ábundance and form the first great "Warbler wave." Thousands of Thrushes, Warblers and Vireos pass through at this time and the woods seem fairly alive with birds. Several other waves occur during May, which are mainly characterized by Warblers, and, indeed, for the first three weeks of the month these birds seem to be passing almost continuously. By the 20th of the month, however, the migration begins to wane, and although stragglers of many species are seen until the 30th, and some Blackpoll Warblers linger as late as June 6, there are rarely any migratory waves after May 20. 
As regards the departure of the winter birds, the records of the club show that the Herring Gulls leave the Delaware river about April 4, and they seem to desert the meadows at Atlantic City, N. J., about the same time.

Winter Wrens, Fox Sparrows and the bulk of the Snowbirds generally leave Philadelphia by April 15, while the Brown Creepers and Golden-crowned Kinglets stay a few days later.

Most of the White-throated Sparrows have departed by May 1, but a few occur regularly as late as the 16th of the month, and one was seen in 1888 on May 27. The straggling Snowbirds have usually left by May 1, but occasionally one is seen a few days later; May 10 being the latest date recorded.

The first evidence of the fall migration in the vicinity of Philadelphia is seen during the last week in July, or, perhaps, earlier, when the old birds of several species leave their breeding grounds and apparently pass slowly southward. By the middle of August most of the Swallows, Kingbirds and Orioles have disappeared from the interior, and begin to congregate along the river valleys, coast lines and other avenues of migration, whence they pass southward gradually as they are joined by flocks from farther north.

Immense congregations of Kingbirds and several species of Swallows are familiar sights at this time along the New Jersey coast.

Grackles, Red-winged Blackbirds, Robins and Bluebirds collect in flocks by August 1, or earlier, but they do not apparently journey southward till later in the season. The pioneer migrants from the north reach Philadelphia during the first week of August, the Water Thrush and Redstart being the earliest to arrive. During the latter part of the month-August 20-31-many other species arrive, such as the Canadian, Black-throated Blue, Chestnut-sided, Bay-breasted, Blackburnian, Magnolia, and Wilson's Warblers, and the Wilson's Thrush. None of 
these birds, however, are abundant at this time, and seem to pass through quickly. The majority of these August warblers that have been collected seem to be old birds, while the large majority of those which pass through later are, as is generally known, birds of the year.

The bulk of the Warblers, Vireos, Tanagers and the Thrushes, which characterize the May migration in the spring, pass through in the fall from September 10 to October 1, and by the end of the first week of the latter month nearly all the stragglers have disappeared.

The October birds correspond in general to those of the April migration, occurring, of course, in inverse order, and by November 1 only a few Hermit Thrushes, Fox Sparrows, Field Sparrows and Myrtle Warblers are left of the migrating birds, while all the winter visitants have arrived in force.

The Snowbirds begin to arrive as early as September 27, though they are not common before the middle of October. The first White-throated Sparrows are seen about September 20, while on the coast the Herring Gulls arrive at Atlantic City about October 1.

Such is a brief outline of the spring and fall migrations in the vicinity of Philadelphia.

* * *

Birds may be arranged in two groups, according to their manner of migration, viz., day migrants and night migrants. The former include the Doves, Hawks, Hummingbirds, Chimney Swift, Nighthawk, Horned Lark, Crows, Jays, Grackles, Blackbirds, Swallows, Cedarbird, Titlark, Bluebird and Robin, and perhaps a few others.

The night migrants include the Woodpeckers, Cuckoos, Flycatchers (except the Kingbird), Meadowlark, Orioles, most of the Finches, the Vireos, Tanagers, Warblers, Wrens, Creepers, Nuthatches, Titmice and most of the Thrushes. 
Among the water birds the Bittern, Woodcock, Wilson's Snipe, Spotted Sandpiper and the Rails migrate exclusively by night, while the other species seem to move by day or night, according to circumstances, most diving birds migrating along the coasts by day but making their overland journeys by night.

From an examination of the foregoing lists it will be seen that the more timid, shelter-loving birds migrate at night, and the bolder species, which are strong of flight or which associate in flocks, migrate by day. The reasons for this can easily be seen in the following quotation from Mr. Brewster's paper on Bird Migration: "Timid, sedentary, or feeble-winged birds migrate by night because they are either afraid to venture on long, exposed journeys by daylight, or unable to continue these journeys day after day without losing much time in stopping to search for food. By taking the nights for travelling they can devote the days entirely to feeding and resting in their favorite haunts. Good examples are Thrushes (except the Robin), Wrens, Warblers and Vireos. Bold, restless, strong-winged birds migrate chiefly, or very freely, by day because, being accustomed to seek their food in open situations, they are indifferent to concealment, and being further able to accomplish long distances rapidly and with slight fatigue, they can ordinarily spare sufficient time by the way for brief stops in places where food is abundant and easily obtained. *** Excellent examples are the Robin, Horned Lark and most Icteridae. Birds of easy, tireless wing, which habitually feed in the air or over very extensive areas, migrate exclusively by day, because being able either to obtain their usual supply of food as they fly or to accomplish the longest journeys so rapidly that they do not require to feed on the way, they are under no necessity of changing their usual habits. The best examples are Swallows, Swifts and Hawks. Nocturnal and crepuscular birds, at least migratory species, are all strong-winged and accustomed to seek 
their food over wide areas. Hence, like Swallows, Swifts and Hawks, they migrate during the hours of their habitual activity."

Day migrants perform their journeys either as scattered individuals, or in compact flocks, there being comparatively little mixture of species. As regards night migrants, however, the case is different. All the species which are migrating on any particular night, being attracted by each others' notes, become more or less mingled together in an immense column, not forming a compact flock, but composed of individuals and small bunches flying sufficiently near to one another to be guided by the chirping of those just ahead. Observations made from lighthouses seem clearly to show this to be the nature of the night migrations, and it is really most natural, being merely a continuation of the actions of these same birds while feeding in the woodland during the day, when they go shifting from tree to tree, the various species intermingled and all slowly following the lead of those just ahead of them. The leaders of these migratory flights are probably old birds which have had the experience of previous migrations and have thoroughly learned the route of travel. The experience of most of the leading ornithologists of this country, however, seems to show that the old birds of most if not all species migrate southward before their young, leaving the nestingground soon after the moult is completed and entrusting their young to the guidance of later migrants, often belonging to quite different species.

Migrating birds seem to follow the same course year after year, so that it is possible to map out pretty exactly their principal lines of flight. These lines of flight foIlow the courses of rivers, valleys, mountain chains, or coast lines, which to the eyes of the migrants, flying high in the air, are distinctly outlined for many miles, provided the night be clear, and thus form easily recognizable landmarks. 


\section{FOOD FOR BIRDS.}

The injury that birds do to crops and fruit is trivial compared to the vast benefits derived from their almost continual warfare against insects and larvae, but even this injury may be obviated in a great measure. As a rule birds prefer wild fruit and seeds to cultivated fruit and grain, and consequently those who desire to derive the greatest benefit from birds will do well to plant some wild fruit which will bear during the weeks the birds usually feed on the garden or orchard crops. In this connection Mr. Forbush says:

"I wish particularly to note the fact that the mulberry trees, which ripen their berries in June, proved to be a protection to the cultivated cherries, as the fruit-eating birds seem to prefer them to the cultivated cherries, perhaps because they ripen somewhat earlier;" and he adds, "I believe it would be wise for the farmer to plant rows of these trees near his orchard, and it is possible that the early Juneberry or shadberry might also be useful in this respect."

Prof. Beal suggests planting berry bushes along the roads and fences and between grain fields.

To protect strawberries and cherries (May and June), plant Russian mulberry and Juneberry or shadberry.

To protect raspberries and blackberries (July and August), plant mulberry, buckthorn, elder and choke cherry.

To protect apples, peaches, grapes (September and October), plant choke cherries, elder, wild black cherry and Virginia creeper.

To protect winter fruits, plant Virginia creeper, dogwood, mountain ash, bittersweet, viburnum, hackberry, bayberry and pokeberry. 
Birds that eat mulberries are the Flycatchers, Warblers, Vireos, Cuckoos, Blackbirds, Orioles, Finches, Sparrows, Tanagers, Waxwings, Catbirds, Bluebirds and Thrushes.

Birds that eat the potato beetle are the Rose-breasted Grosbeak, Cuckoo and Quail.

Birds that eat the tent caterpillar (which does most harm to the apple and cherry trees) are the Crows, Chickadee, Oriole, Red-eyed Vireo, Yellow-billed Cuckoo, Blackbilled Cuckoo, Chipping Sparrow and Yellow Warbler.

Birds that eat the cut worm (which eats off corn, etc., before it is fairly started in the spring, and is very destructive to grass) are the Robin, Crow, Catbird, Loggerhead Shrike, House Wren, Meadowlark, Cowbird, Baltimore Oriole, Brown Thrasher and Red-winged Blackbird.

Ants (which spread plant-lice, destroy timber and infest houses) are the favorite food of the Catbird, Thrasher, House Wren and Woodpeckers; are eaten by almost all land birds except birds of prey.

Scale insects (which are a fruit tree pest, injure oranges, olives, etc.) are eaten by the Bush Tit, Woodpeckers and Cedarbird.

The May beetle (which ravages forest trees, also injures grain and grass lands) is eaten by the Hermit Thrush, Wood Thrush, Robin, Meadowlark, Brown Thrasher, Bluebird, Catbird, Bluejay, Crow Blackbird, Crow, Loggerhead Shrike, Mockingbird and Gray-cheeked Thrush.

Weevils (which injure grain, forage and market gardens) are eaten by the Crow Blackbird, Red-winged Blackbird, Baltimore Oriole, Catbird, Brown Thrasher, House Wren, Meadow Lark, Cowbird, Bluebird, Robin, Swallows, Flycatchers, Mockingbird, Woodpeckers, Wood Thrush, and Scarlet Tanager.

The chinch bug (which eats grain and wheat) is eaten by the Brown Thrasher, Meadowlark, Catbird, Red-eyed, Vireo, Robin and Bob White.

The wire worm (which causes heavy losses in the cornfield) is eaten by the Red-winged Blackbird, Crow Black. 
bird, Crow, Woodpeckers, Brown Thrasher, Scarlet Tanager, Robin, Catbird, Baltimore Oriole, Meadow Lark and Cowbird.

Crane flies (which eat grass roots in the hay fields) are eaten by the Robin, Catbird, Wood Thrush, Gray-cheeked Thrush, Olive-backed Thrush, Crow, Crow Blacklird and Red-winged Blackbird.

The soldier bug is eaten by the Robin, Bluebird, Crow Blackbird, Crow, Catbird, House Wren, Red-winged Blackbird, Baltimore Oriole and Meadowlark.

Birds that eat the cotton worm are the Bluebird, Bluejay, Red-winged Blackbird, Thrush, Quail, Killdeer, Bobolink, Mockingbird, Cardinal and Cuckoo.

Gypsy Moth.-Mr. Forbush, ornithologist of the Massachusetts State Board of Agriculture, gives the following list of birds seen to feed on the gypsy moth: Yellow-billed Cuckoo, Black-billed Cuckoo, Hairy Woodpecker, Downy Woodpecker, Pigeon Woodpecker, Kingbird, Great Crested Flycatcher, Phobe, Wood Pewee, Least Flycatcher, Bluejay, Crow, Baltimore Oriole, Purple Grackle or Crow Blackbird, Chipping Sparrow, Chewink, Rosebreasted Grosbeak, Indigobird, Scarlet Tanager, Red-eyed Vireo, Yellow-throated Vireo, White-eyed Vireo, Blackand-white Warbler, Yellow Warbler, Chestnut-sided Warbler, Black-throated Green Warbler, Ovenbird, Maryland Yellow-throated Warbler, American Redstart, Catbird, Brown Trasher, House Wren, White-breasted Nuthatch, Chickadee, Wood Thrush, American Robin, Bluebird and English Sparrow.

Birds that eat grasshoppers and crickets are the Mockingbird, Thrasher, Bluebird, Wrens, Shore Lark, Goldfinch, Longspur, Grasshopper Sparrow, Song Sparrow, Junco, Lark Sparrow, Rose-breasted Grosbeak, Indigo Bunting, Cardinal, Chewink, Bobolink, Cow Bird, Redwinged Blackbird, Meadowlark, Baltimore Oriole, Orchard Oriole, Rusty Blackbird, Crow, Bluejay, Kingbird, Crow Blackbird, Whip-poor-will, Night Hawk, Swift, Cuckoo, 
Red-headed Woodpecker, Flicker, Barn Owl, Great-horned Owl, Marsh Hawk, Sparrow Hawk, Gulls, Swainson's Hawk, Quail, Shrikes, Swallows, Vireos, Robin and Catbird.

In the Massachusetts Crop Report for July, 1896, Mr. William R. Sessions gives a list of the birds he has seen feeding on the army worm during the present summer: Kingbird, Phoebe, Bobolink, Cowbird, Red-winged Blackbird, Baltimore Oriole, Crow Blackbird, Chipping Sparrow, Robin. 


\section{THE BIRDS OF NEW JERSEY.}

Note. - In the classification of birds an attempt has been made to give them under their common names, by which they are best known in New Jersey, exceptions being made in cases where the birds belong to some species represented by a number of others.

Aluk, Little, Dovekie, or Sea Dove.-Length, eight to nine inches; extent, fourteen inches; bill, half an inch; head, white and black; back, black; breast, upper brown, lower white; belly, white; sides, white; tail, black and white; upper wing, sooty black; under wing, black and white; legs, black; feet, black. It lays one or two eggs, of a bluish white color, one and four-fifths by one and one-fourth inches in size, on ledges and in crevices of rocks. It is a regular winter visitant to the New Jersey coast, coming down from the North Atlantic and Atlantic and Arctic oceans. It feeds on crabs and small fish.

Ank, Razor-billed or Tinker.-Length, sixteen and a half inches; bill, one and a quarter inches, head, black; back, black; breast, white; belly, white; sides, black; tail, black; wings, black; legs, black; feet, black. In winter the front of the neck and the sides are white. It lays one or two eggs, pale blue, spotted with brown, three by two inches in size, in crevices and fissures in rocks. It is a regular winter visitant to the New Jersey coast, breeding in Maine and northward. Its cry resembles a grunt or groan. It feeds on crabs and small fish.

Baldpate. See Widgeon.

Bee Mrartin. See Kingbird. 
Heetle-head. See Black-bellied Plover.

Bittern, Marsh Hen, or Stake Driver.-Length, twenty-seven inches; extent, three feet, four inches; bill, three inches; head, slate, black and brownish yellow; back, brown and brownish yellow; breast, brown; belly, yellowish brown; sides, yellowish gray; tail, brown; upper wing, brown; under wing, white; legs, yellow; feet, yellow. Lays from three to five eggs, of a pale buff color, two inches by one and a quarter in size. The nest is built of grasses on the ground in marshes. It breeds in temperate and tropical North America, as far south as Guatemala, but seldom south of Virginia. It is a regular visitant to New Jersey, being here from April to October, but spends the winter mostly south of the Middle States. The noise made by the bird, Bradford Torrey says, sounds like the working of an old-fashioned pump, a series of "hiccoughs" preceding the "boom." In New Jersey it is occasionally called the "Dunkadoo" from the sound it makes. When disturbed it rises with a kwa. Although it seems to spend most of its time during the day in standing still it is not altogether a nocturnal feeder. It feeds principally on frogs, lizards and snakes.

Bittern, Least.-Length, from twelve to thirteen inches; extent, sixteen inches; bill, one and three-quarter inches; head, black; back, greenish black; breast and belly, white; sides, pale yellow; tail, brown and yellow; upper wing, brown and slate; under wing, yellowish; legs, greenish and yellow; feet, yellow. Its lays from three to six eggs-usually four-of a pale blue, one and one-fifth by one inch in size. The nest is built of grasses and plant stems among the rushes in the marshes. It breeds in temperate and tropical America, northward to Maine, and is a common summer residerıt along the New Jersey coast, going to the Southern States and further south for 


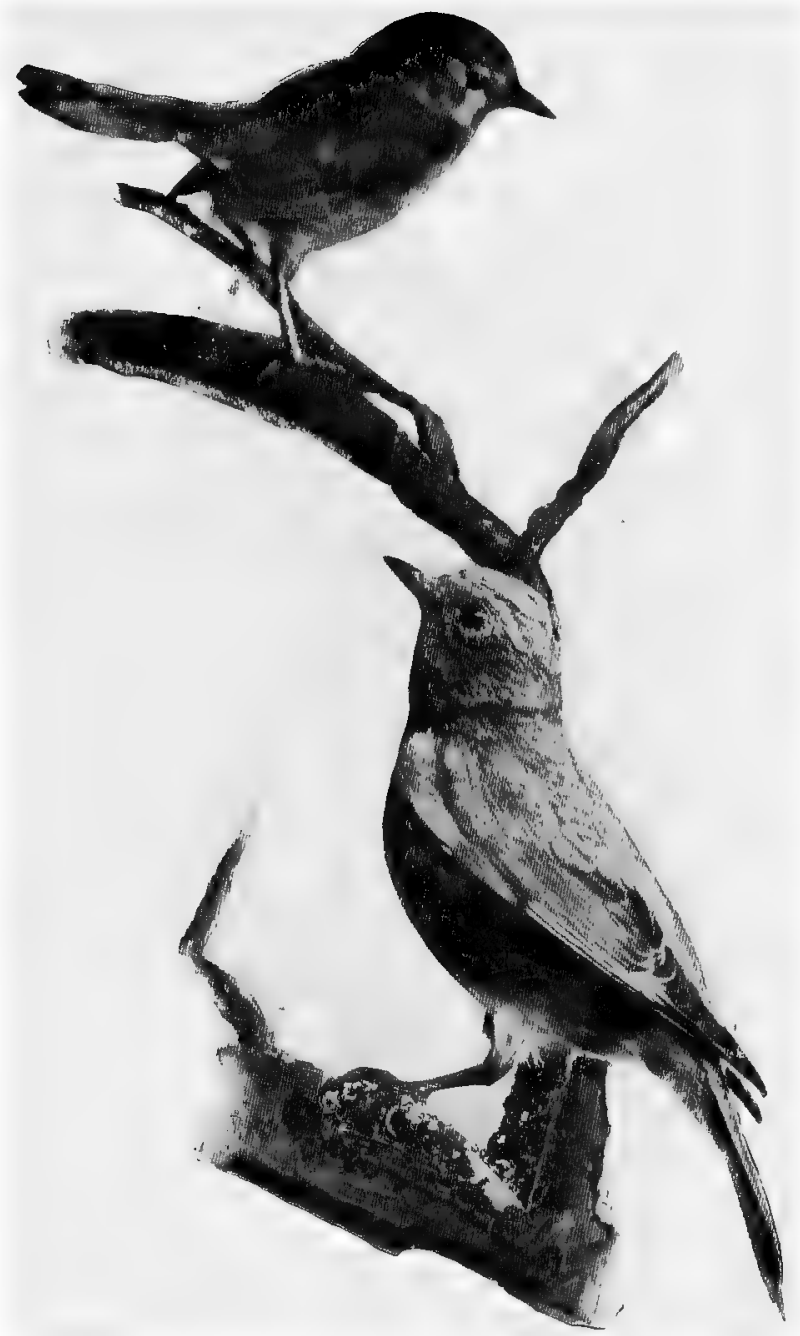

MARYLAN๊D YELLOWTHROAT AND BLUEBIRD. 
the winter. When disturbed it arises with a kwa; its note during the breeding season is a soft coo-coo-coo-coo, somewhat resembling the cooing of a dove. It feeds on small fish, lizards, frogs and other aquatic food.

Blackbird, Crow. See Bronzed Grackle and also Purple Grackle.

Blackbird, Red-winged.-Length of the male, nine inches; of the female, seven and a quarter ; extent, of the male, fourteen inches; of the female, twelve inches; bill, nine-tenths of an inch. The general color is a rich blue black, with the exception of the shoulder of the wings in the male, which are a bright scarlet, and the legs, which are brownish black. The female has no scarlet and presents a rather mottled appearance, the belly being streaked with white and the general plumage being speckled with bay, brown and white. The young birds at first resemble the female, but the males assume the black and red plumage in September when both young and old have a complete moult.

The nest is pocket-like, sunk in a tussock of grass or hung between the branches of low bushes, reeds and alders. It is built about the middle of April, of coarse grasses and weedstalks, lined with finer grass. The eggs are from three to five, one inch by three-fourths in size, of a pale blue, fancifully streaked, spotted and scrawled with dark lilac or black, principally at the greater end.

The birds breed all through temperate North America and pass the winter mainly south of the Middle States. They arrive in New Jersey in February and leave about the first of November, a few wintering in the southern part of the state.

Its alarm note is chee-e-e-e-e, its song a rich onk-la-ree-e.

Its food consists principally of weevils, with other insects, grasshoppers, grub worms, army worms and caterpillars; its regetable diet consists of wild rice and corn; 
when feeding on the latter it also takes the worm under the husk. When wintering here it feeds on the seeds of ragweed and birdweed.

\section{Blackbird, Rusty, or Thrush Blackbird.-Length,} nine to nine and a half inches; extent, thirteen to fourteen inches; bill, four-fifths of an inch. The coloring of this bird, when breeding, is a glossy blue black, but in the fall and winter the plumage is bordered with rusty markings which give it a decided brownish tint; the female, while breeding, is of a slate color, but in fall and winter is veiled in rusty like the male. The nest is a bulky affair, built in trees or on the ground, of twigs and coarse grasses, lined with finer grasses. There are from four to seven eggs, gray green in color, with brown or purple spots, one inch by three-fourths in size. The birds breed north of the northeastern boundary of the United States and winter south of the Middle States. They are seen in New Jersey, principally in the river marshes, in March and October; occasionally one is found to winter, when the season is mild. They arrive in pairs and are very shy and retiring. Their song, very seldom heard, is a confusion of harsh whistles; the call note a cluck.

Blackhead. See Greater Scaup.

Blackhead, Little. See Lesser Scaup.

Blackbreast. See Red-backed Sandpiper.

Blmebill. Ste Greater Scaup.

Hluebiu, Little. See Lesser Scaup.

Bluebird. Lengh, six and a half inches; extent, eleven inches; bill half an inch; the head, tail and the wings are of a bright sky-blue with purple reflections; breast, brown; belly, white; legs, black; soles of feet, yel- 


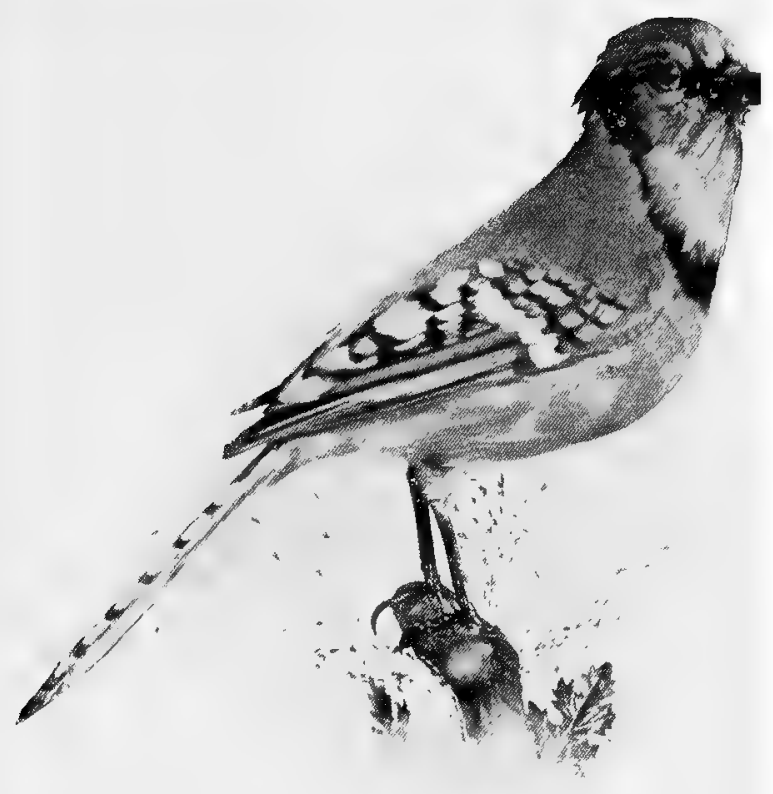

BLULEJAY. 

low. In the fall the plumage is tipped with brown. The female is of a duller cast than the male.

The nest is composed of a few twigs and grasses in a hollow tree, decayed knothole, abandoned woodpecker hole, or a bird house. Mating begins in March and the male is one of the most jealous and attentive of lovers; when he finds a particularly juicy insect or other delicious morsel he almost invariably carries it to his mistress and he resents the approach of another male in the most warlike manner. The eggs are from four to six in number, of a bluish and rarely of a clear white color, four-fifths by three-fifths of an inch in size. There are generally two or three broods in a season.

The birds inhabit the whole of the eastern part of the United States, being the first to arrive in the spring and apparently leaving their summer homes with regret, for they postpone their southward flight until the trees and bushes are bare. Some remain regularly throughout the winter. During the past few years the Bluebird has rapidly decreased in number throughout its range and unless it again increases may soon be ranked as a rare bird.

Their call note is tur-wee, tur-wee. The song is a plaintive and oft-repeated warble, likened by Burroughs to purity, purity, and by Mabel Osgood Wright to Dear, dear, think of it! Think of it!

Their food consists principally of large beetles and of such insects as they gather out of dead and decaying treees.

Bluejay.-Length, eleven and three-quarter inches; bill, one inch; head, crested, light blue or purple; back, lead blue; breast, bluish white with black crescent; belly, white; sides, dirty white, stained with purple; tail, blue, with black bars and white tips; upper wing, blue; under wing, barred with black and tipped with white; legs and feet, black.

The nest is very large and is built of very closely woven roots; it is located in a tree crotch, generally between fif- 
teen and twenty feet from the ground. The eggs are from four to six in number, of an ashy green with brow' 1 spots, and one and one-fifth by four-fifths of an inch is size.

The birds breed, throughout the eastern part of the United States. They gather in large flocks in August, September and October, and at the approach of cold weather the majority go south, although considerable numbers remain here, especially in the southern part of the state.

The cry of the bird is Jay, jay, jay.

This bird has been frequently charged with being very destructive to other birds and to grain, but a government examination of 280 stomachs, collected at all times of the year, showed that in only three were there birds' eggs and in only two birds; seventeen per cent. of the food was corn and twenty-two per cent. insects-grasshoppers and caterpillars predominating in the latter. Observation has shown that the bird prefers acorns, chestnuts, hazelnuts and beechnuts to corn, and that it does not take the latter unless impelled to do so by a scarcity of other food. It is an inveterate enemy of large beetles and makes existence miserable for the owls.

\section{Blue Peter. See Coot.}

\section{Bobolink, Reed Bird, Rice Bird, or Rice Bunt-} ing.-Length, seven and a half inches; bill, half an inch; extent, eleven and a half inches. In the spring the coloring of the male is as follows: Head, black and cream; back, black, seamed with brownish yellow, the lower part grayish white; breast, belly and sides, black; tail, black; wings, black; legs, brownish flesh; feet, black. In the month of August this plumage is entirely moulted and a new dress donned, which is buff, like that of the female, with the back streaked with brownish black; whole lower parts, dull yellow. The black dress is acquired by an- 


$$
\text { d }
$$



other moult in spring and is at first broadly margined with buff, but this gradually wears off. The young males retain the dress of the female until the early part of the succeeding spring; the plumage of the female undergoes no material change of color.

The nest is built on the ground in meadows or hayfields and is a rude contrivance of grasses and is not easily seen. The eggs are from four to seven in number, four-fifths by three-fifths of an inch in size, of clear gray with brown and blackish clouds and spots.

The birds come from south of the Amazon early in the spring and spread themselves over the whole of the northeastern United States and Canada, arriving here about the first of May. The males frequently precede the females by several days. Some few remain in northern New Jersey to breed, but large numbers go farther north. These return in the latter part of August, but we have large numbers with us until the latter part of September, when most have passed southward, although frequently considerable numbers remain until late in October. The migration southward begins in August and continues right along.

Their song is delightful, but incoherent; it begins when the birds reach Florida in their northward spring migration and continues until after the young have been hatched, when it changes to a simple call, resembling a metallic chink. Wilson says of their song: "Some idea may be formed of this song by striking the high keys of a pianoforte at random, singly and quickly, making as many sudden contrasts of high and low notes as possible. Many of the tones are in themselves charming, but they succeed each other so rapidly that the ear can hardly separate them." Burroughs compares the song to $H a$ ! ha! ha! I must have my fun, Miss Silverthimble, if I break every heart in the meadow! See, see, see. Thoreau says: "It is as if he touched his harp with a vase of liquid melody and when be lifted it out notes fell like bubbles 
from the strings. *** Away he launches and the meadow is all bespattered with melody.'

The food of the birds consists of insects, young corn, wild oats and reeds. It is the latter which brings the birds in large flocks to the meadows along the Hackensack and Delaware. Coming north the birds do a great deal of damage to the oats and wheat in Virginia and going south they eat a great deal of rice in the Carolinas. It is stated, on no very reliable authority, that these birds did not migrate north until after rice cultivation had been begun in the Carolinas; it is, however, pretty certain that the rice fields materially increased the number of these birds.

Bob W'hite, or Quail.-Length, nine inches; extent, fourteen inches; bill, one-third of an inch; head, black and brown; back, red brown, sprinkled with ash and black; breast, upper part reddish brown, lower part yellowish white; belly, pale yellow white; tail, ash, sprinkled with reddish brown; wings, plain dusky; legs, pale ash. The female has the chin and sides of the head a yellowish brown, whereas in the male the chin is pure white, bounded by a band of black.

The nest is usually built about the first of May on the ground in grassy fields, usually at the bottom of a thick tuft of grass; it is made of leaves and fine dry grasses, partly covered above and with an opening on one side. The eggs are from ten to twenty, pure white in color and one and one-fifth by one inch in size.

The birds inhabit the whole of the eastern United States, as far west as Kansas and as far south as Georgia, but have become quite scarce in thickly settled districts.

The cry of the bird is Bob White.

Its food consists of grain, seeds, insects and berries; it is very fond of buckwheat and also of potato bugs.

Brant.-Length, twenty-six inches; extent, three and 


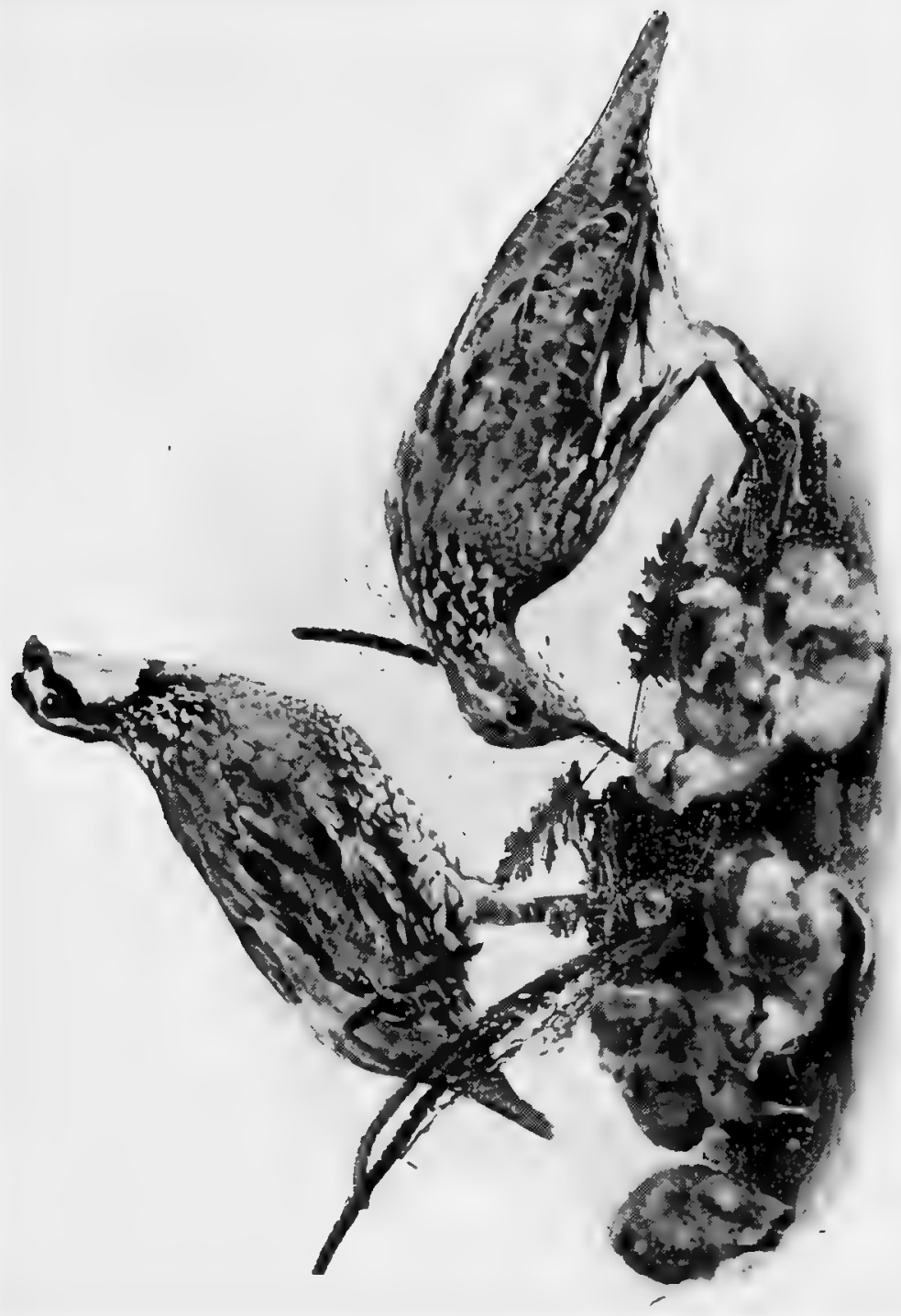

点 

a half feet; the female is somewhat smaller. Head, black; back, brown gray, grayish brown at the edges; breast, the upper part black and the lower part ashy gray; belly, white and sides darker; tail, black with a great deal of white; upper wing, black and white; under wing, brownish gray, with some white; legs and feet, black.

The nest is built on the ground, of grasses and mosses, lined with down. The eggs are four in number, of a creamy white color, two and three-fourths by one and three-fourths inches in size.

The birds breed somewhere up in the Arctic circle and arrive in New Jersey on the fall flight about the first of October. A few winter along the New Jersey coast, but most of them go farther south, many wintering in Virginia.

The principal food of the Brant is eel-grass.

The Black Brant, which very much resembles the above, but being much darker on the lower breast and. upper belly, is an exceedingly rare winter visitant, straggling in from the west.

Brantbird. See Turnstone.

Broadbill. See Greater Scaup.

Broadbill, Creek. See Lesser Scaup.

Brown Mrarlin. See Marbled Godwit.

Brown Thrasher or Brown Thrush.-Length, eleven and a half inches; extent, fourteen inches; bill one inch ; head and back, reddish brown; breast, yellowish white with spots of black; belly, yellowish white; sides and tail, reddish brown, the former with spots of black ; upper wing; reddish brown ; under wing, dusky ; legs, dusky clay. The female may be distinguished from the male by the white on the wing being much narrower and the spots on the breast less. 
The nest is built in old brush piles, or, if these are not convenient, in brambles. On the outside it is composed. of coarse roots ; then follows a layer of leaves and the inside is lined with fine fibrous roots. The eggs are from three to six in number, bluish or greenish white, finely speckled with brown, one and one-fifth by four-fifths inches in size. There are two broods a year.

The birds breed from the Middle and Eastern States to Florida and winter in the southern part of the United States. They arrive in New Jersey towards the latter part of April and leave shortly after the middle of October. They are very seldom seen here in winter.

The alarm note of the bird is wheeu and the song is of the bravura style. Thoreau says that while the farmer is planting his corn the Brown Thrasher sings, Drop it, drop it, cover it up, cover it up, cover it up, pull it up, pull it up, pull it up; another lover of birds likens it to Look up, Look up, Glory to God, Glory to God, Glory to God, Hallelujah, Amen, videlicet.

Government analyses of 121 stomachs show that the contents consisted of 63 per cent. insect and animal matter and 35 per cent. vegetable matter, the rest being sand. Of the animal matter one-half was composed of beetles; 11 per cent. was matter from cultivated crops, of which 8 were fruit and the rest grain. The food of the bird changes with the supply, being seven parts insects and one part vegetable in May.

Bull-bat. See Night Hawk.

Bunting, Bay-winged. See Vesper Sparrow.

Hunting, Imaigo. See Indigo Bird.

Bunting, Snow. See Snowflake.

Butcher Bird. See Northern Shrike. 


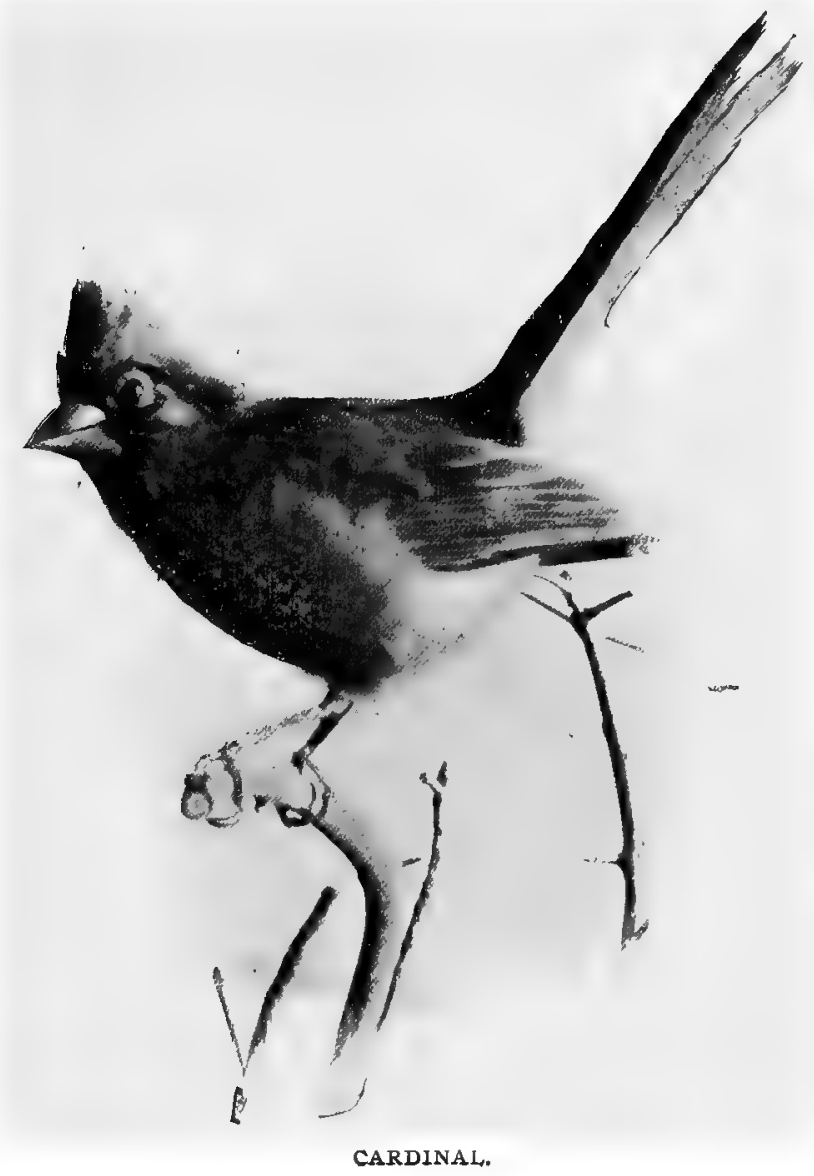


Butter-ball. See Buffle-headed Duck.

Calicoback. See Turnstone.

Canary, Woild. See Goldfinch.

Canvasback. See Canvasback Duck.

Cardinal, Cardinal Grosbenk, or Mirginia Nightingale.-Length, eight and a quarter inches; bill, three fifths of an inch; extent, eleven inches; head, conspicuously crested, of a bright vermillion, tipped with grayish; the bill red, and black about the base. The color of the bird is a uniform rosy red, the legs being light clay and the feet darker to brown. The female is brownish gray, lighter beneath and tinted with dull red. The birds of both sezes are excellent providers for their young and the male is a devoted husband.

The nest is a bulky affair, built in bushes, of twigs, roots and bark, lined with fine grass. The eggs are three or four in number, one inch by seven-tenths in size, white with spots of red and brown.

The birds breed in the eastern United States east of Iowa and are residents all through New Jersey, being numerous in the southern part. A large number winter here, some, however, going further south. The bird has been introduced into France and England as a cage bird and in the latter country has been named the Virginia Nightingale.

Its call note is tsip and its song a clear whistle resembling the word Peace, peace, with the ea long drawn out.

Its food consists principally of worms, grubs and insects.

Catbird.-Length, nine inches; extent, thirteen inches, bill, three-fifths of an inch. The bird is of a deep slate color, the tail being black and the under part 
of the tail chestnut. The legs and feet are black.

The location of the nest depends altogether on the treatment the bird receives; if treated kindly the nest will be found in the lilac bush, on the piazza or in some bush near the house; if it is driven away the nest will be found in the thickest brush of the woods. Its nest is built of twigs, grasses, leaves and small roots. It generally has two broods a year. The eggs are from three to five in number, of a rich green blue, one inch by seventenths of an inch in size.

The birds breed throughout the United States, coming to New Jersey about the first of May and returning southward about the middle of October; a few stragglers sometimes pass the winter here.

It would be almost impossible to describe the song of the bird, as it is generally composed of the notes of other birds and consequently varies with locality. Its call is a rasping feline note, like the mewing of a cat. Its note of alarm sounds something like zeay, zeay.

Government reports of the examination of 213 stomachs indicate that one-thirds of its food is insects, onethird wild fruits and one-third cultivated fruits. Among insects it prefers beetles, ants, caterpillars, crickets and grasshoppers in the order named.

Cat Owt. See Long-eared OwI.

\section{Cedarbird, Cedar Woxwing, or Cherry Bird.} -Length, seven inches; extent, eleven inches; bill, onefourth of an inch; head dark fawn, crested; back, dark fawn ; breast, light blue ; belly, yellowish ; sides and tail, bluish gray; wing, a deep slate with a little fawn and white, tipped with small red appendages like sealing wax on the ends of several of the quills; legs and feet, black. The red tips are independent of sex and age; some birds have them, some do not.

The nest is from five to twenty feet from the ground in 


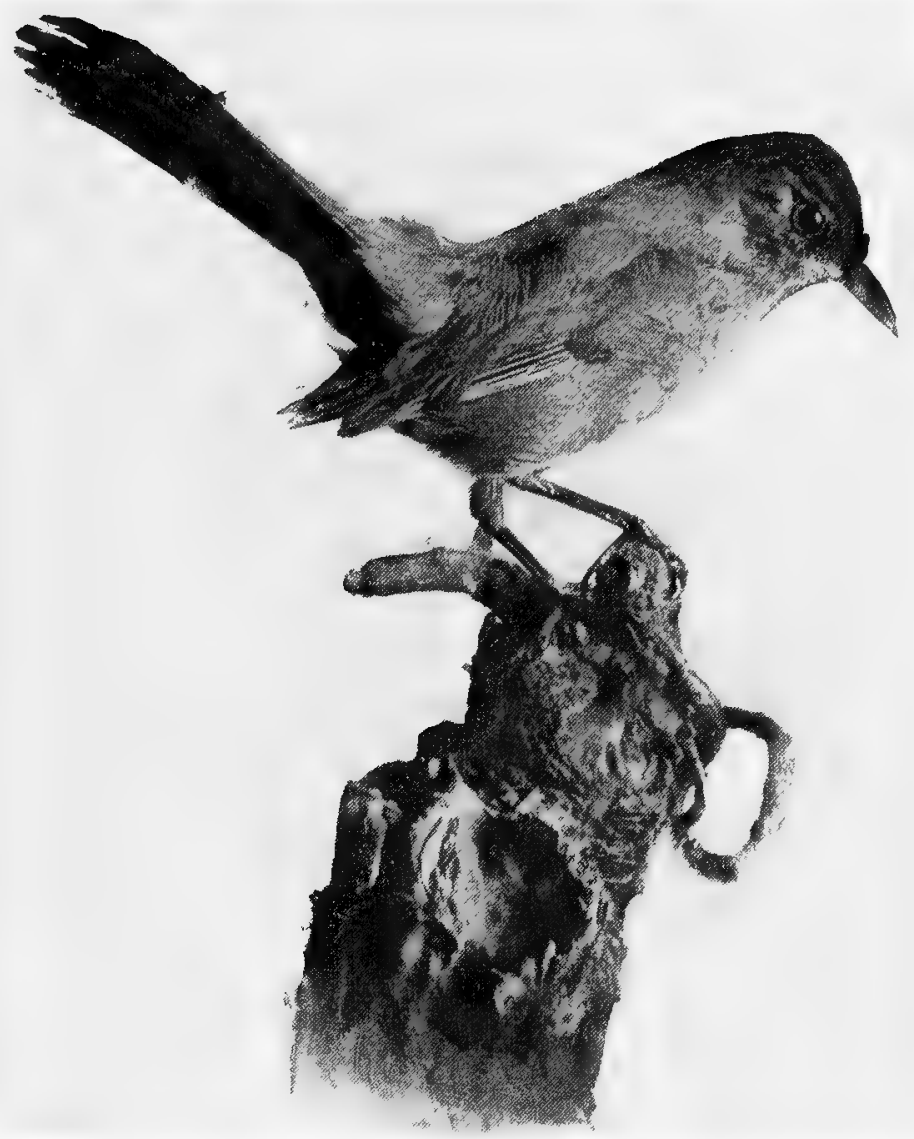

CATBIRD. 

fruit or shade trees; it is a bulky contrivance, made of roots, twigs, grass, moss and sometimes mud. The eggs are from three to five in number, nine-tenths by threefifths of an inch in size, of a dingy blue white, thick at one end and tapering suddenly.

The birds breed throughout temperate North America, spreading south, wintering from the northern United States to Central America ; in New Jersey they are scarce in winter and occur in great flocks early in summer.

Their call is referred to by Thoreau as a "beady note," twee-twee-zee.

Government analyses of 125 stomachs show that only seventeen per cent. of the total food consists of insects, the rest being made up of the pulp, skin and seeds of fruits and sometimes seeds and other parts of flowers; they consume the most insects when fruit is most abundant and feed their young to a great extent on insects; in winter they subsist to a large extent on cedar berries.

Chat, Yellow-breasted.-Length, seven and a half inches; extent, ten inches; bill, two-fifths of an inch; the back, tail and upper wings are of a rich olive green with a brownish glaze; breast, bright yellow; lower belly, white; sides, bright yellow; under wing, bright yellow; legs and feet, light lead.

The nest is built about the middle of May in a crotch of a bush near the ground; it is a bulky contrivance of coarse grasses, roots and bark compactly interwoven and lined with fine grasses and plant fibre. The eggs are from three to five in number, white in color with brown spots and nine-tenths by three-fifths of an inch in size.

The birds breed in the eastern part of the United States, comparatively few being found in the northern part of New Jersey. They are here from May to September and spend the winter in Mexico and further south.

Their alarm note is a chut, chut, chut, and their song a mixture of caws and whistles, varied and frequently 
mocking in tone.

They feed principally on insects and berries, preferring large black beetles and whortleberries.

Chebec. See Least Flycatcher.

\section{Cherry-bird. See Cedarbird.}

\section{Chewink, Towhee, Joree, Ground Robin, or} Swamp Robin.-Length, from seven to nine inches; extent, from ten to twelve inches; bill, half an inch; head, back and breast, black; belly, white; sides, bright bay; tail, black, tipped with white; wings, black, with one or two white spots; legs and feet, dirty flesh. The female has the upper part and breast grayish brown.

The nest is a large and substantial structure, built on the ground and sometimes half way into it, and well-hidden under brush; it is frequently found in a thicket of briars. It is built of leaves and bark and lined with fine grasses. The eggs are four or five in number, white in color with fine brown spots, and one inch by seven-tenths of an inch in size. There are generally two broods a year.

The birds breed from the Southern States northward to British America and spend the winter in the south from Virginia to Florida. They frequent principally the dry uplands and pine barrens. They arrive in New Jersey about the middle of April and leave about the middle of October.

Their call cry is Chewink or Tohee, and Ernest Thompson has likened their song to Chuck-burr-pill-a-will-awill- $\alpha$.

The birds are very industrious in hunting insects, worms and larvae, and in the fall feed on berries and hard seeds.

Chickudee, Black-capped, or Titmonse.-Length, five and a half inches; extent, six and a half inches; bill, two-fifths of an inch; head, black; back, leadcolored; breast, belly and sides, grayish white; tail and 


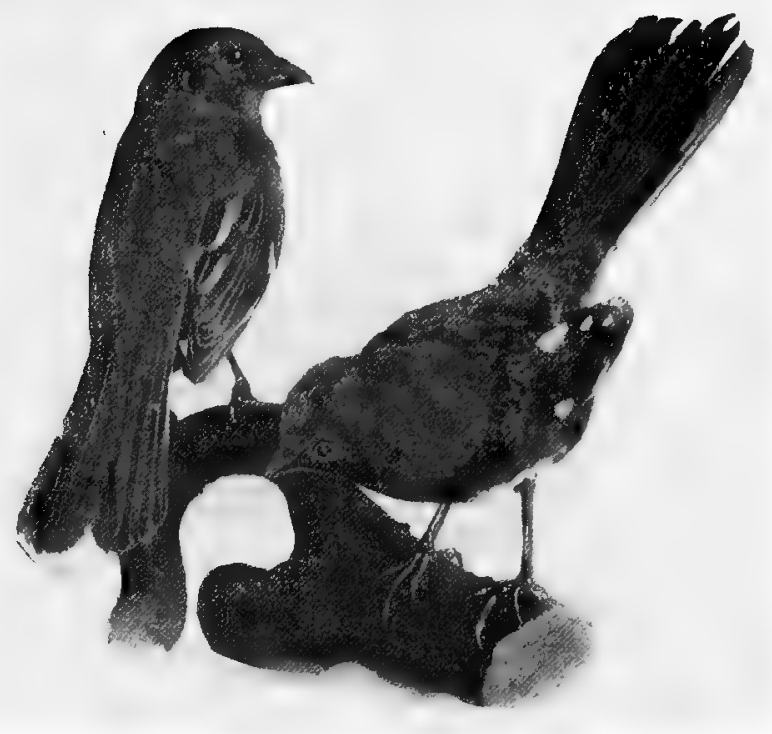

CHEWINKS. 
 , 
wings, lead-colored with white margin; legs, light blue.

The birds nest in an old stump or hole in a tree, fifteen feet or less from the ground; the nest is made of moss, grass, feathers, hair, fur and plant down. The eggs are from five to eight in number, three-fifths by one-half inch in size, white with brown spots principally near the larger end. There are two broods in one year.

The birds are regular winter visitants in New Jersey, and breed in the northern counties.

Their song in the summer is Chick-a-dee-dee-dee, in winter Chick-a-day-day-day.

Their food consists principally of insects with very little fruit. In an article on "Birds as Protectors of Orchards," Mr. E. H. Forbush, of the Massachusetts Board of Agriculture, says of the Chickadees: "There is no bird that can compare with it in destroying the female cankerworm moths and their eggs." $\mathrm{He}$ calculated that one Chickadee in one day would destroy 5,550 eggs, and in the twenty-five days in which the canker-worm moths run or crawl up the trees 138,750 eggs. Mr. Forbush attracted Chickadees to one orchard by feeding them in winter, and he says that in the following summer "it was noticed that while trees in neighboring orchards were seriously infested with canker-worms and to a less degree with tentcaterpillars, those in the orchards which had been frequented by the Chickadees during the winter and spring were not seriously infested and that comparatively few of the worms and caterpillars were to be found there." His conclusion is that birds that eat eggs of insects are of the greatest value to the farmer, as they feed almost entirely on injurious insects and their eggs, and are present all winter, when other birds are absent. In southern New Jersey this species is replaced by the following, except in winter, when both occur.

Chickadee, Carolina.-Length, four inches; extent, six inches; bill, one-third of an inch. This bird is scarce- 
ly distinguishable from the preceding, but is somewhat smaller and has less white margins to the wings and tail.

They nest in holes in trees, frequently in cavities dug by themselves, the nest being built of grass, bark, feathers and hair. The eggs are from five to eight in number, one-half by two-fifths of an inch in size, white, spotted with brown at the larger end.

They breed in the south eastern United States, being plentiful in southern New Jersey and extremely scarce in the northern part of the state. They remain here all the year.

The song is a tremulous My watcher key, changing to a plaintive tewee-dee, tewee-dee.

Their food consists principally of insects, with very little fruit, being frequently occupied in looking for insects and larvae in acorns, nuts and rotten parts of bark.

Chippy. See Chipping Sparrow.

Chippy, Winter. See Tree Spårrow.

Clape. See Flicker.

Coot, Crow-duck, or Blue Peter.-Length, fifteen or sixteen inches; extent, twenty-eight inches; bill, fourfifths of an inch. It is of a slate color with a black head and an ivory-white bill, an inch and a half long; the wings and tail are tipped with white and the legs and feet are greenish. It builds its nest of reeds and grasses, in fresh water marshes, the number of the eggs being eight to fifteen, the color pale yellowish white, thickly speckled with brown, and the size one and four-fifths by one and one-fourth inches. It breeds from the northern United States northward and spends the winter in the southern United States and Central America. It arrives in New Jersey in April, but is more plentiful in the fall migration towards the end of September or first of Octo- 


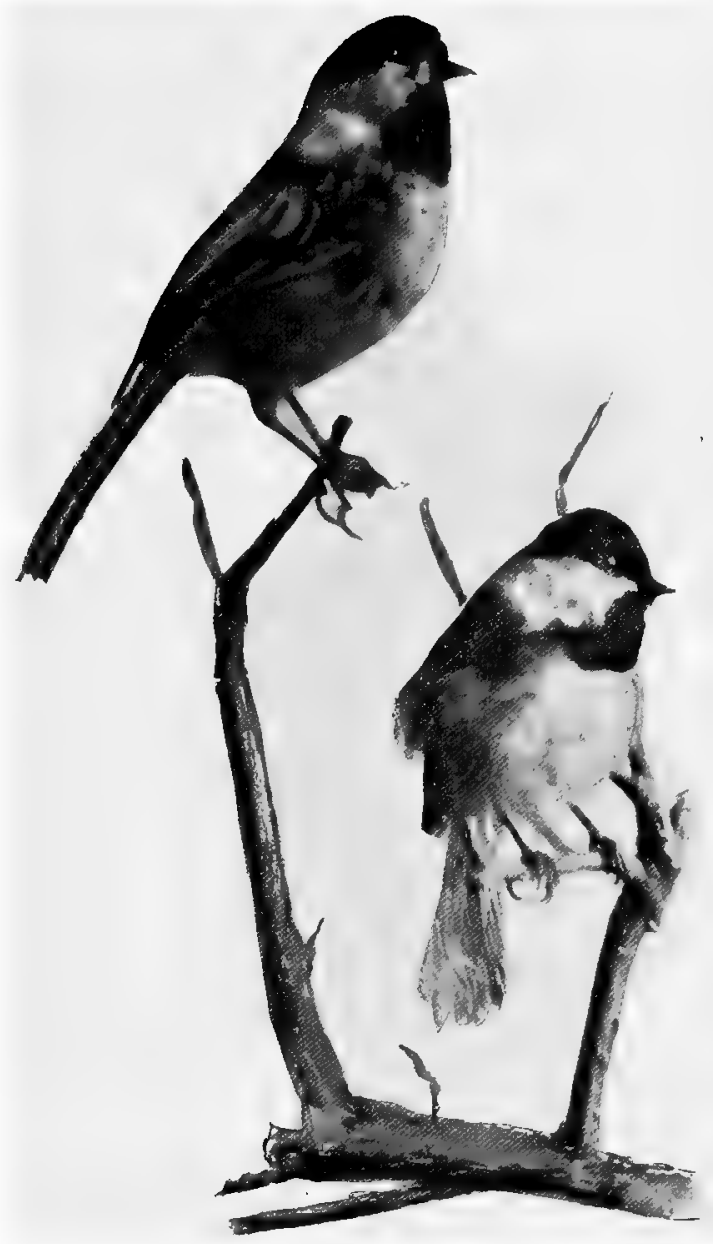

CHICKADEES. 

ber. It is generally found in large rivers and bays. Its food consists of aquatic plants and grasses.

Coot, Rlack. See American Scoter.

Coot, Sea. See Surf Scoter.

Coot, White-winged. See White-winged Scoter.

Cormoramt, or Shag. - This bird is a rare visitor to New Jersey, breeding from New England to Greenland and in the winter months coming south occasionally as far as New Jersey. It is thirty-six inches in length, the bill being three inches, and the general color a glossy black ; the upper wing is black and brown and the head is sprinkled with white; the back is a light brown. It breeds on rocky cliffs, surfaces of rocky islands and sometimes in trees, the nest being conical and made of sticks and seaweed. The eggs are from four to six in number, of a pale bluish white, two and a half by one and a half inches in size. Its food is fish.

Cormorant, Double-crested.-This bird is very similar to the foregoing, the principal difference being that it is six inches shorter, the bill two-thirds of an inch shorter, and that the belly is a glossy black, the upper part being grayish brown. The eggs are from two to four in number, somewhat smaller than those of the preceding but similar in color. It breeds from the Bay of Fundy northward and in the winter goes south as far as Maryland. It is very common in New Jersey during migrations and in fact all winter. Its food is fish.

Cow Bird.-Length, seven inches; extent, eleven inches; bill, two-thirds of an inch; head, a silky drab. The rest of the plumage is black with a gloss of green or purple when viewed in certain lights. The female is uniformly gray. 
This bird is about as disreputable as a bird well can be and this fact seems to be accepted by others of the bird kind. Although occasionally seen in company with a Red-winged Blackbird it had no companions until the introduction of the English Sparrow, when it found a congenial companion. It builds no nest under any circumstances, but drops its eggs-which are white, evenly speckled with brown and different shades of gray, and nine-tenths by seven-tenths of an inch in size-into the nests of other birds, invariably selecting those of birds smaller than itself and those of a mild and affectionate disposition. It is a well known fact that birds do not lay their eggs for a day or two after the completion of a nest; should the Cow Bird drop an egg into a nest in this interim the chances are that it will be thrown out or that the rightful owner of the nest abandons it. But if an egg or two has been laid in a nest by its builder the chances are that the addition of an egg by a Cow Bird will pass unnoticed and that the bird will rear the offspring thus foisted upon it. As soon as large enough to fly the young birds join those of their kind.

The bird spends its winter in the southern United States and Mexico and comes north about the first of April, returning south in October; large numbers go farther north in the spring. Some winter in the southern part of New Jersey.

Its cry is about as unmusical as it can possibly be, somewhat resembling cluck-see.

About the only redeeming trait of the bird is its almost constant chase after insects and worms; it generally follows the cattle, picking up seeds and insects from the droppings and from hoofs. It also frequently destroys grasshoppers.

Crane, Blue. See Great Blue Heron. 
Creeper, Black and White. See Black and White Warbler.

Creeper, Brown.-Length, five inches; extent, seven inches; bill, two-thirds of an inch; head, brownish black; back, brown with yellow and white streaks; breast, grayish white; belly, white; tail, pale grayish brown; upper wing, brownish black, with whitish brown bars; under wing, dusky white and black; legs and feet, a dirty clay color.

The nest of this bird is located behind the loose bark of a tree and made of twigs, bark and moss very closely re sembling the color of the place it is built on. The eggs are from five to eight in number, three-fifths by one-half inch in size, white, with brown spots; sometimes with a pink tinge.

It breeds from the northern border of the United States northward and also further south on the higher mountains, and in winter is distributed throughout the eastern United States. In New Jersey it is a common winter resident, arriving about the middle of September and remaining until about the middle of April.

Although in the north it is said to render exquisite song, in New Jersey it is confined to a few squeaky notes. In fact, the bird does not seem to have time to sing, his whole existence apparently being taken up looking for insects and larvae in trees. It ascends the tree, beginning at the very root and encircling it as it goes up; when it reaches the top it drops down to the root of another tree and thus keeps up a continual pilgrimage, ever alert for food.

Crossbill, American, or Red Crossbill.-Length, five and three-quarter inches; extent, nine inches; bill, two-thirds of an inch. This bird is a very irregular visitor in New Jersey, occasionally occurring in winter in small flocks, but generally confining itself to mountain- 
ous ranges farther inland. Its plumage is of a dull red, brighter on the rump and darker on the back; the wings and tail are of dark slate, the tail being edged with red. The female is a little smaller and of a greenish color; the wings and tail brownish black, edged with green. The bills of both are crossed at the end, this apparent malformation being made good use of in securing the seeds from the cones of the pine trees, the principal food of the bird. Its nest is made of twigs and grasses, lined with small roots and plant fibre. The eggs are three or four in number, of a pale green with brown spots, three-fourths by four-fifths of an inch in size.

Crow.-Length, eighteen and one-half inches; extent, three feet and two inches; bill, two inches. The general color is a shining, glossy, blue black with purplish reflectious; the throat and lower parts are less glossy; the bill is two and a quarter inches long, very strong, and covered at the base with thick tufts of recumbent feathers. The female differs very slightly from the male, being more dull colored and rather deficient in the glossy and purplish tints and reflections.

The nests are found in trees about thirty feet from the ground, evergreen trees being preferred. The nests are bulky structures of sticks, lined with strips of bark, moss or hair. Mating begins in March and extends through April and May. The eggs are from four to six in number, one and three-fifths by one and one-fifth inches in size. The color is a blue green, mottled with shades of brown.

The Crows breed and are distributed over the whole of North America. In winter they desert New England, their migrations as a rule, however, being very limited and generally only for the purpose of securing a better supply of food.

The call note of the bird is a caw, in the spring a quavering kar-r-er.

Whether the crow is a harmful bird or whether its 
good traits more than counterbalance the mischief it does is a question which has given rise to a great deal of discussion. The government has made very exhaustive inquiries into the feeding habits of the bird, the results of which have been published in book form. The results of these investigations, the contents of the stomachs of nine hundred and nine crows taken at all times of the year having been analyzed, have been summarized by Dr. C. Hart Merriam, Chief of the Division of Ornithology and Mammology, as follows:

"The most important charges brought against the Crow are: (1) That it pulls sprouting corn; (2) That it injures corn in the milk; (3) That it destroys cultivated fruit; and (4) That it feeds on the eggs and young of poultry and wild birds. All of these charges are sustained by the stomach examinations, so far as the simple fact that Crows feed upon the substances named. But the extent of the injury is a very different matter. In order to ascertain whether the sum of the harm done outweighs the sum of the good, or the contrary, the different kinds of food found in the stomachs have been reduced to quantitative percentages and contrasted. The total quantity of corn eaten during the entire year amounts to 25 per cent. of the food of adult Crows, and only 9.3 per cent. of the food of young Crows. Leaving the young out of consideration, it may be said that in agricultural districts about one-fourth of the food of Crows consists of corn. But less than 14 per cent. of this corn, and only 3 per cent. of the total food of the Crow, consists of sprouting corn and corn in milk; the remaining 86 per cent. of the corn, or 97 per cent. of the total food, is chiefly waste grain picked up here and there, mainly in winter, and of no economic value. In the case of cultivated fruits the loss is trivial. The same is true of the eggs and young of poultry and wild birds, the total for the year amounting to only one per cent. of the food. As an offset to his bad habits, the Crow is to be credited with the good done in 
destroying noxious insects and other injurious animals. Insects form 26 per cent. of the entire food, and the great majority of these are grasshoppers, May-beetles, cutworms, and other injurious kinds. It is shown by Mr. Schwarz that during the May-beetle season, in May and June, these beetles form the principal insect food of the Crow. Only a few stomachs do not contain them, and stomachs are often filled with them. The fact that the May-beetle season coincides with the breeding season of the Crow is of special importance, the principal insect food of nestling Crows consisting of these beetles. Mr. Schwarz also finds that grasshoppers occur in the stomachs throughout the year; that during the May-beetle season they occur in the vast majority of stomachs, but usually in moderate numbers; that with the disappearance of May-beetles towards the end of June they increase in number until in August and throughout the fall they constitute by far the greater part of the insect food, often occurring in astonishing numbers, and often forming the only insect food. To the same side of the scale must be added the destruction of mice, rabbits, and other injurious rodents by the Crow. In summing up the benefits and losses resulting from the food habits of this bird, it is clear that the good exceeds the bad and that the Crow is a friend rather than an enemy of the farmer."

\section{Crow Blackbird. See Purple Grackle.}

\section{Crow Blackbird. See Bronzed Grackle.}

\section{Crow, Duck. See Coot.}

Crow, Fish.-Length, sixteen inches; extent, thirtythree inches; bill, one and a half inches. The general color is a jet black, with blue and purplish reflections and somewhat greenish on the upper part. It is very similar to the common Crow, both in appearance and nesting. The eggs are four to six in number, one and a half by 
one inch in size. It frequents the Gulf and Atlantic coasts as far north as Connecticut and some remain here all winter, although the vast majority go further south at the approach of cold weather. Its cry is the same as that of the common Crow, but hoarser and more gutteral and with a nasal twang. Although it obtains most of its food along the seashore it is also frequently seen along inland rivers, invariably resorting to woods for roosting and nesting. Its food is confined to fish, shell-fish and lizards, and garbage and offal found floating on the surface of the water.

Crow, Rain. See Cuckoo.

Cuckoo.-Length, thirteen inches; extent, sixteen inches; bill, three-fourths of an inch. There are two kinds of Cuckoos, very nearly allied, the black-billed and the yellow-billed, the latter being the most numerous. In the Yellow-billed Cuckoo the whole upper parts are of a glossy drab, with greenish silk reflections; from this must be excepted the inner webs of the wing feathers, which are a bright reddish cinnamon; the two middle tail feathers are like the back, the others black, largely tipped with white; the whole lower parts are pure white; the legs and feet are light blue. The general color of the Black-billed Cuckoo is nearly that of the yellow-billed, but the tail feathers are all colored like the back, the outer ones with very slight tips of black and white; the wings also want the bright cinnamon, while the bare eyelids are of a deep red color; as indicated by the name the lower mandible in one species is yellow and in the other black. The upper mandible is black in both. The females differ little in appearance from the males.

Unlike the European Cuckoo the American bird builds its own nest, although it is not a very pretentious affair, being composed of small sticks and grasses; that of the 
black-billed is more compact. It is very flat and is built in the early part of May in a low tree or bush, from five to ten feet from the ground. The eggs are from three to - four in number, of a pale greenish blue, in the blackbilled the greenish hue being deeper. The eggs are about one and a fourth by nine-tenths of an inch in size, those of the black-billed being a trifle smaller, or about one and one-tenth by four-fifths of an inch.

The birds arrive in New Jersey from the West Indies and Mexico about the middle of April and remain until September. They are distributed throughout the eastern and middle portions of the United States.

Their cry is $k u k-k u k-k u k$, harsh and grating; their song is composed of tut-tut-tut, cluck-cluck-cluck, kowe-kowekowe. The first notes are repeated rapidly at first, getting gradually slower, and the last somewhat drawn out.

The food of the Cuckoo consists principally of caterpillars, the bird evincing a particular liking for those that infest apple-trees ; fifty or sixty are found at a time in its stomach and the interior of the latter presents the appearance of a felt hat from the deposit of the hairs of the caterpillars. It also at times feeds on the larvae of insects and a few berries. The black-billed confines itself almost exclusively to small shell-fish, snails and larvae such as are found near or in streams, and is consequently not so valuable a bird.

Curlew, or Jack Curlew.-Length, seventeen inches; extent, thirty-two inches; bill, three and three-fourths inches. The upper parts are a dull brown mottled with buff, the belly being whitish or a light buff, streaked with dusky on neck and breast, tail barred with dusky. Their breeding location is in the far north; the number of eggs is three or four, of a pale brown color and two and a quarter by one and a half inches in size. The birds are common along the coast of New Jersey in May 


$$
h
$$



and again from the middle of July to the middle of September. Their food consists of worms, crickets, beetles, snails and small shell-fish.

Dab Chick. See Pied-billed Grebe.

Diedapper. See Pied-billed Grebe.

Diver, Great Northern. See Loon.

Dove.-Length, twelve inches; extent, nineteen inches; bill, half an inch. The general appearance of the bird is a bluish fawn color. Above it is an olive brown, varying to a bluish gray, with a few black spots on the back and inner wing feathers; the sides of the neck have metallic tints; the belly is of a vinaceous cinnamon, changing to a buff and lead color on the sides; the bill is black and the feet red. The tail feathers are gray with large terminal spots of white or gray, light gray preceded by a black band; central pair, uniform brown. In the female the colors are somewhat duller.

The nest is frequently nothing but a deserted robin's nest, flattened out and a few sticks placed upon it; when the bird builds its own nest, generally in the lower branches of a tree or in a garden, it is a rudely constructed affair composed of small twigs. Mating begins in April. The eggs are two in number, of a white color, one inch by four-fifths of an inch in size.

The bird breeds over the whole of North America as far north as Canada. It arrives in New Jersey in April from the southern part of the United States and returns in November, although a few winter in the southern part of the state.

Their cry is a soft, plaintive Coo-o-o, ah-coo-o-o-coo-o - coo-o-o.

The food of this bird consists of grain and corn, but the latter is very seldom taken from the ear; it very rarely feeds on insects. 
Dove, Sea. See Little Auk.

Dovekie. See Little Auk.

Dowitcher, or Red-breasted Snipe.-Length, ten and a half inches; extent, eighteen inches; bill, two and a quarter inches. This bird has a mottled appearance on account of its being spotted with black; the back is black, barred with light buff, the under parts reddish buff, spotted with round black dots; the long wing feathers are black, tail barred with black and white. In winter it is much grayer above and white beneath, streaked with dusky on the neck. It breeds in the far worth and spends the winter in Florida, Mexico and South America. It arrives in New Jersey during the latter part of May and again during the latter part of July. Its eggs are four in number, of a light brown, spotted with deep brown, and one and three-fifths inches by one and one-tenth in size. In winter the plumage changes to a brownish gray.

The Long-billed or Western Dowitcher is occasionally seen in small numbers in company with the foregoing; it has a longer bill and its plumage is considerably darker. It is very similar to the Dowitcher but very much rarer.

Duck, Black, or Dusky Duck.--Length, twentytwo inches; extent, thirty-three inches; bill, two and onefifth inches. The general coloration above is a deep dusky, slightly tipped with buff. The bill is greenish yellow; below the body is streaked with dusty brown and cinnamon; the tail sooty brown, the upper wing sooty brown and the legs and feet yellowish red. In the female there is more brown. The nest is a mat of marsh grass built on the ground, the eggs being from eight to twelve in number, of a light greenish or bluish yellow, two and a half by one and threefourths inches in size. It breeds in the Middle States as far north as Hudson's Bay; it arrives in New Jersey during the latter part of October and remains un- 
til about the middle of March. Its winter distribution extends to the South Atlantic states. Its food is composed principally of shell-fish and its flesh has a delicate flavor. When molested it frequently passes a day at sea. A few probably breed in this state.

\section{Duck, Brodd-bill.-See Scaup.}

\section{Duck, Bufhe-head, Butterball or Spirit Duck.} -Length, thirteen to fifteen inches; extent, twenty-two to twenty-five inches; the head is puffy and over the back of the head from eye to eye runs a broad white band; the rest of the head and neck is a purple green and blue gloss; the bill is only an inch long, being very short; back, black; wings, black and white; breast, belly, and sides, white; the tail ashy gray and pointed. The female is somewhat smaller; whole upper parts sooty brown, with a white patch on each side of the head; breast and belly, dull white; tail, brown. The young males resemble the females. The nest is built in a hollow tree or stump, the eggs being from six to twelve in number, of a light yellow color, two inches by one and a half in size. Its breeding location is far northward and it spends the winter in New Jersey and as far south as Cuba and Mexico. It remains in New Jersey from about the first of November to the middle of April and is most numerous along the seacoast and in large rivers. It is a great diver and a very swift flyer. The food consists of small fish, shellfish and shrimp, and it it considered a fair table bird.

\section{Duck, Butter-ball. See Buffle head Duck.}

Duck, Canvasback.-Length, twenty-one to twentyfour inches; extent, three feet. The bill is black, two and a half inches long; the neck is a reddish brown and the chin and crown dusky; the upper back is black, the lower white with fine wavy black lines; breast, black; belly, white, the lower part with fine black wavy 
lines; sides, white; tail, brown, short and pointed; wings, gray, with specks of black; legs and feet, pale ash. The female has the neck and upper breast brown; the back is a grayish brown with many wavy white lines and the white on the belly is duller than in the male. It nests only in the interior, on the ground, in marshes near the water; the number of eggs is from six to ten, blue white in color, two and two-fifths by one and three-fourths inches in size. Its breeding location is northward of the northwestern part of the United States and in winter it spreads itself from the Chesapeake to Mexico, being rare in New Jersey. Its food consists of frogs, lizards, tadpoles, fish, grasses and the roots thereof; it is considered a great table delicacy, especially after it has been feeding on eel-grass, or wild celery, for some time, although by some it is considered inferior to the Redhead Duck.

Duck, Dusky. See Black Duck.

Duck, Golden-eye. See Golden-eye.

Duck, Gray, or Gadovall.-Length, nineteen and a half inches; extent, thirty-one inches; bill, one and threefourths inches; head, brown, black on top, and sides of head buff, spotted with black; breast, black, pencilled with white, giving it the appearance of scales; belly white, dull white or gray; tail, tapering, of a pale brown edged with white; wings, black and brown; legs and feet, orange red or yellow; in the female the breast and sides are yellowish, the belly is white and there is more white on the wings. The eggs number from eight to twelve, of a pale yellow, two inches by one and a half in size. Its breeding location is in the northern interior and in the winter it spreads itself over the South Atlantic states and southward, being rare in New Jersey, one being occasionally shot on the coast. It is accorded a good table bird. 
Duck, Long-Tail. See Old Squaw Duck.

Duck, .Mallard.-Length, twenty-three inches; extent, three feet; bill, two and a quarter inches. The bill is a greenish yellow; head and neck, glossy greenish and bluish black, with a white collar around the neck; upper part of the back, a dark grayish brown, growing darker near the tail; breast, brown; belly, grayish white, with wavy black lines; sides, pale gray, waved with darker; tail, mostly white, with some gray, brown and black; wings, above, grayish white, waved with black, patch of bright glossy blue feathers with white band around the middle; legs and feet, orange red. In the female the whole plumage above and below is mottled with brown and light buff, lighter beneath. It nests on the ground near water, the nest being composed of grass, weeds and feathers. The eggs are from six to ten in number, of a pale yellowish or bluish white, two and a half by one and threequarter inches in size. Its breeding location is the northern hemisphere and in winter it is distributed throughout the temperate region; in New Jersey it is more frequently found on the rivers than along the coast. Its quack cannot be distinguished from that of the domestic duck. Its food is principally vegetable and its flesh is considered excellent.

\section{Duck, oMerganser. See Merganser.}

\section{Duck, old Squaw, Old W'ife, Long-tail or South} Southerly.-Length, about twenty-three inches, depending a great deal on the length of the tail, which varies; extent, from thirty to thirty-four inches; bill, one inch. The female is somewhat smaller, being sixteen inches in length and twenty-eight in extent. The front and sides of the head are gray, the back of the head yellowish white; the back, black and gray; breast, belly and sides, white; the tail is long and pointed, black; wings, black; legs and 
feet, dusky slate. The male in summer has the breast and upper belly black, and upper surface black and white with no gray tints; female duller than male. The nest is built on the ground, near water, under low bushes or in tall grass; it is made of grass and lined with down. The eggs are from six to twelve in number, of a bluish white with dark slate spots and two by one and one-half inches in size. It breeds in the far north and during the winter goes as far south as Chesapeake bay; it arrives in New Jersey late in October and remains until the middle of April, being abundant along the coast and occasionally found in the rivers. It is a very noisy duck, having a sonorous musical voice, its cry resembling "South Southerly," from which one of its names is derived. It is not particular as to its food, frequents the salt water and is seldom found far from the sea. On account of its devouring so many fish its flesh has a fishy taste.

Duck, Pintail, or Sprigtail.—Length, about thirty inches, somewhat depending on the length of the tail, which varies; extent, three feet; bill, two inches; head, brown; also the back of the neck, except two white lines which run up to the back of the head; breast, white; back, belly and sides, white, with fine wavy lines of black; tail, long, very much pointed, black and gray; wings, gray, inner feathers long and pointed, black with buff edges, spot on wing glossy green; legs and feet, lead. The female presents a somewhat more mottled appearance, the breast being yellowish, the back dark slate, the tail shorter and dark brown with white spots. The nest is built on the ground, near water, of grasses and weeds. The eggs are from six to twelve in number, of a yellowish or bluish white, two and one-fifth by one and one-half inches in size. Its breeding location is the northern United States and northward and in the winter it goes as far south as Cuba and Panama. It is transient in New 
Jersey, being seen along the coast from the latter part of October to the middle of November, although occasionally stray specimens are found later in the winter. Its cry is confined to a very low quack heard only at night. It feeds principally on mud flats and in shallow fresh water marshes and its flesh is considered excellent for the table.

Duck, Redhead.-Length, from nineteen to twentythree inches; extent, two feet and six inches; bill, one and three-fourths inches. In all plumages resembles the Canvasback, but is distinguished by the much darker back, which is dark gray instead of nearly white. The bill is also shorter than in the Canvasback and does not run so far up on the forehead.

It builds its nest on the ground, in marshes near water. The number of eggs is from six to twelve, of a dull white color, two and two-fifths by one and three-fourths inches in size. It breeds north of Maine and in winter migrates as far south as Mexico. It is an occasional visitor to New Jersey from the first of November to the first of March. Its food is principally vegetable, being the stems of grasses in salt and brackish water. Its flesh is considered a table delicacy.

Duck, Ring-necked.-Length, sixteen and a half inches; extent, twenty-eight inches; bill, one and fourfifths inches. The head is black and there is a chestnut collar around the neck. The back is black; the breast is black; the belly is white, with fine black lines over the lower part and sides. In the female brown takes the place of black in the plumage. It builds its nest on the ground, in marshes near water. The eggs are from six to twelve in number, of a dull bluish white, two and one-fourth by one and three-fifths inches in size. It breeds north of the United States and in winter goes as far south as Guatemala. It is scarce in New Jersey, although a few are occasionally seen on the rivers and bays between November and March. 
Duck, Ruddy.-Length, Fifteen inches; extent, twenty-two inches; bill, one and one-half inches; head, top black, the cheek and chin white; lack, a bright mahogany, darker lower down; breast, mahogany; belly, gray; tail, black, greatly tapering; wings, drab; legs and f.eet, ash. The female has the upper parts grayish brown, as has also the young bird. It builds a nest on the ground near water. The eggs are from six to ten in number, of a yellowish white, two and a half by one and three-fourths inches in size. Its breeding location is northward of the United States and in the winter it goes further south. It is seen occasionally along the coast of New Jersey, but is more plentiful in the rivers. Its food is principally vegetable and its flesh is considered excellent for the table.

Dack, Scaup. See Scaup.

Duck, Scoter. See Scoter.

Duck, Spirit. See Buffle-head Duck.

Dack, Sprigtail. See Pintail Duck.

Duck, Summer. See Woud Duck.

Dack, Teal. See Teal.

Duck, Whistler. See Golden-eye.

Duck, Wialgeon.-See Widgeon.

Duck, Wood, or Summer Duck.-Length, nineleen inches; extent, two feet and four inches; bill, one und a third inches, red, margined with black; the front l'own and crest is a rich, glossy, bronze green, ending in violet and with lines of white; sides of the upper neck and cheeks, violet; chin, throat and collar around the neck, pure white; breast, maroon brown, with minute tri- 
angular spots of white which increase as they spread into the white of the belly; each side of the breast is bounded by a crescent of white and that by a broader one of deep black; sides of body buff, finely waved with black lines; the wings are glossy blue black, the outer feathers edged with silvery white; the tail is very tapering, black glossed with green and dusky below; the legs and feet are yellowish red. In the female the head is slightly crested and the chin and throat are white; the head and neck are a dark drab, upper surface of body brown, under surface white, more or less mottled with dusky.

The nest is generally built near the water in a hollow tree, or if this is not convenient in the fork of a tree, frequently at a considerable distance from the ground. The nest is built of sticks and lined with down taken from the breast of the parent bird. In New Jersey the duck begins breeding about the last of April or the first of May. The eggs are generally thirteen in number, being two and an eighth inches by one and a half inches in size and oval in shape. The color is generally slightly yellowish, very fine-grained and of a bigh polish; at times the eggs have a greenish tint, the difference in color being supposed to be due to the age of the bird.

The breeding location is temperate. North America and Cuba and its distribution is about the same, although in extreme cold weather in the north some frequen'ily migrate south; in addition to those which winter here migrants arrive about the first of April and many of these remain all winter.

The cry of the drake is peet, peet, and when standing sentinel while the female is busy with the nest, oe-eek, oeeek.

The food of these birds consists principally of acorns, seeds of wild oats, weed seeds and insects.

Eagle.- A few Bald Eagles still find their homes in 
New Jersey, but they are becoming scarcer every year. Occasionally a number are seen in migrations. The Golden Eagle is merely an occasional straggler from the west and is seen very rarely. The Bald Eagle is nearly three feet in length and sometimes measures six or seven feet from tip to tip of wings ; bill, two and a half inches. The general color of the plumage is a dark slate, the head, neck and tail being white and the bill yellow. The young birds lack the white head and tail. It nests in trees, the number of eggs being two or three, the color gray and the size three inches by two and one-fourth. Its food is principally fish, which it either picks up along the shores or takes away from some industrious fish-hawk or kingfisher; also small animals and carrion. The Golden Eagle is only a trifle smaller than the Bald Eagle; the general coloring of the plumage is a slate brown, with a yellowish tint on the head and some white at the base of the tail. Its nest is built on cliffs and rocky ledges; the eggs are two or three in number, gray with brown spots. The Golden Eagle can always be distinguished from the Bald by having the legs feathered all the way to the toes, while the latter has the lower part of the legs bare.

\section{Egret, White, or White or Snowy Heron.-This} most beautiful and elegant bird is little more than a remembrance in New Jersey, the gun of the markethunter having almost exterminated it. Its long, drooping feathers have long been in demand for aigrettes. Formerly numbers of them were seen in the southern part of the state and perhaps a few breed there yet, but the demand for their feathers for millinery has almost exterminated them, even in the Southern Atlantic states, where they were formerly very numerous. This bird is about two feet in length, its bill being three and a half inches long. Its plumage is of a pure white; the legs are black and the feet yellow. It builds a nest of sticks in bushes overhanging the water, the number of the eggs being three to five, the color a 
dark blue and the size one and four-fifths by one and onefifth inches. They formerly bred in large colonies in the cedar swamps in the southern part of the state and occasionally a few are seen there yet in August and September. Their food consists of frogs, lizards, small fish and small water snakes, insects and seeds of the splatterdocks.

Falcon. See Duck Hawk.

Finch, Gold. See Gold Finch.

Finch, Grass. See Vesper' Sparrow.

Finch, Pine, or Pine Siskin.-This bird is five inches long and nine in extent; bill, two-fifths of an inch. The head and back are light brown, streaked with black; beneath, white, with a buff or sulphur tint and streaked with black; tail, blackish, with the base sulphur yellow; wings, dark blackish, with margin of yellow and with base of quills yellow; legs and feet, brown.

It builds its nest in the upper branches of evergreen trees; the nest is made of twigs and small roots, lined with plant down and hair. The eggs are two-thirds of an inch by half an inch in size, of a pale greenish blue with brown spots; they are four in number.

Its breeding location is in the northern part of the United States, extending southward along the tops of the mountains. It is an irregular visitant in New Jersey, from the middle of October to the middle of March; it is very erratic in its movements and at times appears in large flocks and again in company with the Goldfinch.

Its song is similar to but less musical than that of the Goldfinch and seldom heard here.

Its food is confined to seeds, preferring those of the black alder.

Finch, Purple.-Length, six and one-fourth inches; extent, nine inches; bill, half an inch, brown in color; 
the general plumage of the male adult is a raspberry red; back, duller; belly, grayish white; sides, gray, with dull red streaks; tail and wings, dark slaty brown, with red on the edges; legs, dark purplish flesh; feet, brown. The plumage of the female is wholly unlike that of the male, being of a dark grayish brown, with black streaks, the belly being white, with brown streaks. The young males resemble the female in plumage.

The nest of this bird, almost invariably built in evergreen trees, is made of twigs and small roots and lined with hair ; the eggs are four-fifths by half an inch in size, of a light blue with slate spots, and from four to six in number.

The birds breed in New England and the Alleghanies and occur in New Jersey frequently in flocks from the first of October to the first of May, some going further south during severe winters.

The song, frequently heard especially in large river valleys, is a very sweet warble.

The food of the bird is confined almost wholly to buds and small berries; they are especially fond of cherry blossoms and in the spring frequent the elm trees along with the Goldfinches, feeding on the soft buds.

Firebird. See Baltimore Oriole.

\section{Flicker, Golden-winged Woodpecker, Yellow-} hammer, High-hole or Clape.-Length, twelve inches ; extent, twenty inches ; bill, one and one-third inches ; back, brown, transversely barred with black; head, gray, with a light red crescent on the hind neck ; rump, white; throat and neck, pinkish cinnamon; breast, with a broad crescent-like patch of black; rest of under surface dull white, tinged with cinnamon and thickly marked with round black spots; wings and tail beneath golden yellow; tail above black, shafts yellow, and feathers at its base barred black and white; feet, bluish. The male may be 
distinguished from the female by the presence of black stripes from the base of the bill.

The nest is a hole dug in the trunks of dead trees and resembles that of the hairy woodpecker. Mating begins in April or May. The eggs are from six to eight in number, of a pure white and one and one-tenth by four-fifths of an inch in size.

The bird breeds and is distributed over the whole eastern part of the United States as far west as the Rocky Mountains. Some winter in New Jersey, but most of them go south towards the end of October, returning towards the end of March.

The song is termed by Audubon "a prolonged, jovial laugh, a cuh-cuh-cuh, wick-wick-wick," rapidly repeated. The call is a nasal kee-yee.

The food of this bird consists of beetles, bugs, caterpillars, ants, grasshoppers, corn, buckwheat, berries, fruit, poison ivy berries and sumac berries. Government analyses of 230 stomachs showed that these contained fiftysix per cent. of animal matter, bugs, etc., 39 per cent. vegetable matter and five per cent. of sand and mineral matter. Over forty per cent. of the food of these birds consists of ants, as high as three thousand each being found in several stomachs. Other stomachs contained from eighteen to forty-eight grasshoppers.

Flycatcher, Acadian.-Length, five and three-quarter inches; extent, nine inches; bill, one-third of an inch; above, uniform olive green; wings and tail, brownish, the former edged with dull white; beneath, white tinged with olive; sides, yellowish; feet, dusky; bill, dusky above, yellow beneath. Sexes alike.

The nest is so shallow that the eggs can sometimes be seen from underneath; it is built of plant stems and grasses and frequently of blossoms of oak; it is generally found in the fork of a slender branch about six or eight feet from the ground. The eggs are three or four in num- 
ber, of a pinkish white, with a few brown spots near the large end and three-fourths by one-half an inch in size. The birds arrive from the south shortly after the first of May and return about the middle of September; they are scarce in northern New Jersey, but rather plentiful in the southern part of the state. Their cry is a spee-peet and at other times a heek-yup. The birds are strictly insectivorous, feeding on insects of all kinds.

\section{Flycatcher, Crested, or Great Crested Flycatch-} er.-Length, eight and one-half inches ; extent, thirteen inches ; bill, three-fifths of an inch; above, olive, tinged with brown on the head; wings, dusky, edged with yellowish white, the longest feathers bordered with cinnamon; tail, dusky brown, the inner webs of all but the middle feathers tawny cinnamon; throat and fore breast, gray; rest of under surface bright sulphur yellow ; bill and feet, horn color. Sexes alike. The feathers of the head are elongated and can be erected into a crest, as is the case with most of the Flycatchers.

The nest is built in the hollow of a tree or post and sometimes in an abandoned woodpecker hole, seldom higher than twenty feet from the ground; it is made of twigs, small roots, grasses, feathers, hairs, bristles and almost invariably of a piece of cast snake's skin. The eggs are from three to six in number, of a creamy white, streaked lengthwise with brown and purple, nine-tenths by seven-tenths of an inch in size. The birds come from the south to the eastern part of the United States about the first of May and leave about the first of September; they are far more common than the Acadian Flycatcher. Their cry is a harsh call or squeak, something like the Kingbird's. The birds feed almost exclusively on ground beetles in May and during the rest of the season devour large numbers of other insects; they also devour huckleberries and a little fruit.

Flycatcher, Least or Chebec.-Length, five inches; 
extent, nine inches; bill, half an inch; above, brownish olive, darker on the head; wings and tail, dusky, the former edged with dull white; below, dull white, tinged with olive brown; belly, pale sulphur yellow; bill and feet, dusky. Sexes alike. This little bird is very similar to the Acadian Flycatcher, but may be distinguished by its smaller size and browner coloration.

The nest, generally in a vertical crotch, is made of bark, fibres, small roots and hair, and lined with plant down. The eggs are from three to five in number, white in color and three-fifths by one-half inch in size. The birds arrive in the eastern United States from the south about the first of May and remain until the middle of September. They frequent gardens and orchards and are far more numerous in the northern part of New Jersey than in the southern. Their note is chebec, chebec. Their food consists of insects, frequently caught on the wing, and bees and berries, huckleberries being preferred.

Flycatcher, Tyrant. See Kingbird.

Flycatcher, Yellow-bellied.-This bird is rare in New Jersey, occurring occasionally in the southern part of the state about the middle of May and again about the first part of September. Size about the same as the Least. Above, bright olive green; wings, dusky, bordered with yellowish; tail, dusky; whole lower surface, bright sulphur yellow, breast with a darker olive tint. May be distinguished from either the Least or Acadian Flycatchers by the yellow and olive colors of the fore breast, which is nearly white in both these species.

They breed in the north and spend the winter in the south, merely remaining in New Jersey long enough to rest and feed.

Gadwall. See Gray Duck.

Gallinule, Florida.-This bird passes over New 
Jersey in its spring and fall migrations; it is a regular but rare visitant, occuring in New Jersey about the first of May and again in September and the first part of October. It is thirteen and a half inches in length and the general color of its plumage is of a dark slate, with a suffusion of brown. Its bill is four-fifths of an inch in leng th and red in color. It bas a bare bright red plate on the top of the head, extending half an inch between the eyes; belly, light gray; tail, slate on the upper surface and white underneath; legs, green. Its loud chuck is occasionally heard, but only on large rivers, which it frequents for food, this consisting of small animals, seeds and vegetable growths. Its flesh is considered excellent for the table.

Gamin. See English Sparrow.

Gannet.-This bird is extremely scarcein New Jersey, one being occasionally taken along the coast. They breed north of New Jersey and spend the winter in the south. The Gannet is about thirty-five inches in length and its plumage is white, with a suffusion of straw yellow, especially on the head; the larger wing feathers are of a dark slate. The birds generally appear in small straggling flocks, flying over the ocean in search of fish, which they take from the water.

Gnatcatcher, Blue-Gray.-This bird is very rare in New Jersey and has been found only in the southern part, where it breeds occasionally. It nest is a beautiful lichen covered structure, closely resembling that of the Hummingbird, but larger. It frequents the highest branches of trees and is very shy. It is about four and a half inches in length; above, blue gray, with a jet black band across the nostrils, and a white edging to the innermost wing feathers. The under parts are a gray-white and the tail is black and white. The female lacks the black band over the nostrils. 
Godwit, Hudsonian.-This bird is a rare transient visitor along the coast of New Jersey, a few being occasionally seen late in September. Length, fifteen inches; bill, three inches; back, dull brown, somewhat mottled with white; head, whitish, with dusky streaks; below, dull white or buffy. In summer the head, neck and under surface of body change to chestnut color.

Godwit, Marbled, or Brown Marlin.-This bird is a rare visitor along the coast of New Jersey, a few being occasionally seen in May and then again in August and September. Length, seventeen to twenty inches; bill, three and one-half to five inches; above blackish brown, mottled with pale cinnamon or ochreous in spots and bars; long wing feathers brown on outer web, inner webs ochreous, finely speckled with brown; tail and under parts all transversely barred with pale cinnamon and dark brown; young birds are nearly uniform pale cinnamon below.

Golden-eye, or W'histler.-Length, twenty inches; bill, one and three-quarter inches; head, all around glossy greenish black, large white spot on each side at the base of the bill; neck and entire under surface of the body, pure white; back, greenish black, wings, black; middle feathers white and stripe from shoulders white; tail, grayish black; female has the head brown, whole back gray, slightly mottled; male in winter similar to female.

Its nest is built in a stump or hollow tree; the eggs are from six to ten in number, of a pale blue color and two and one-third by one and three-fourths inches in size. It breeds in Maine and northward, and in the winter goes as far south as Cuba and Mexico. In New Jersey it is found, principally on the coast and on large rivers, from the first of October to the first of April. It feeds principally on small fish and shell-fish and its flesh is of a poor quality for the table. 


\section{Goldfinch, Yellowbird, Thistle Bird or W'ild} Canary.-Length, five inches; extent, eight inches; bill, two-fifths of an inch; body above and below bright canary yellow; top of the head, wings and tail black, the latter with the inner webs of the feathers white; bill, reddish brown; wings and shoulders in early summer banded with white. Female similar but duller in color; never bright yellow. In winter the body plumage is entirely changed. The bird is then brown above and dull white below, with more or less yellow tints on the head and throat of the male and prominent white edgings to wing and tail. During the spring moult, when the change of plumage occurs, the birds are curiously speckled.

The nest is built from five to thirty feet from the ground in the crotch of a tree or bush; it is a neat contrivance, made of fine grasses, bark and moss, lined with thistle-down. Mating begins in June. The eggs are from three to six in number, of a pale blue white, and three-fifths by one-half an inch in size.

The bird is distributed all over the United States, but is scarcer in winter in the northern parts. It is very plentiful in New Jersey.

Its song lasts until August and is very much like the canary, the call note being ker-chic-chic-chic-a-wee-weewee.

The food of the bird consists of the seeds of trees and bushes or almost any seed-bearing plant; it is particularly fond of sunflowers and clematis and in the spring of the year is frequently seen in large numbers feeding on the young pods of the elm trees.

Goosander. See American Merganser.

Goose, Canada, or Common W'ild Goose. - Length, thirty-five to forty inches; bill, two inches; head and neck, black, with a large white band across the throat, reaching from ear to ear; back and upper side of wings, slate gray; feathers with lighter edges; below, pale gray- 
ish white, slightly mottled on the sides; long wing feathers and tail dusky. Sexes alike.

Its breeding location is in the north; it appears in New Jersey shortly after the first of October; large numbers continue on their flight further south, generally passing over the interior part of the state; considerable numbers, however, remain all winter, not leaving until the latter part of April. Their food while here is composed principally of sea cabbage and the rocts of sedge.

Goose, Greater Snow.- Size the same as the Canada Goose; plumage everywhere pure white; except the long wing feathers, which are black; bill and feet, red. Young birds are more or less mottled with gray, especially on the upper parts. There is often a rusty stain on the feathers of the head. It is very seldom seen in New Jersey, passing over the state at times in the annual migration from Greenland to the south and return.

\section{Greenback. See Golden Plover.}

Grackle, Bromzed, or Crow Blackbird.-This bird is seen in New Jersey only in migrations, and is very closely related to the following, in the description of which the distinguishing points are given.

Grackle, Purple, or Crow Blackbird.-Length, twelve inches; extent, eighteen inches; bill, one and onefifth inches. When seen at a distance this bird appears plain black, but at reasonably close range its plumage is at once seen to be resplendent with metallic hues of green, blue and purple. There is great individual variation in color and one style grades gradually in to another.

The head, neck and breast are generally uniform, either metallic, green, blue or red-purple, while the back and lower breast are generally mottled with all three tints; the rump is bronze and the wings and tail purplish. The Bronzed Grackle, a very closely related bird, has the 
entire body plumage metallic bronze except the head, neck and fore breast, which are blue or purple. The female Grackle is much duller than the male. The young during their first summer have scarcely a trace of metallic coloring, being uniform dull black.

The nest is built about thirty feet up a tree, although also sometimes found in a bush or in a hole in a tree. It is bulky but very compactly built of coarse grasses, lined with finer grasses. The eggs are from three to six in number, one and one-fifth by four-fifths of an inch in size, very variable, but generally a pale blue or a blue green, with brown and black scrawls; different sets in the same colony are frequently very unlike.

The birds breed on the Atlantic slope, generally in colonies, from Georgia to Massachusetts. The winter is spent in the south, very few remaining here after the first of November; they arrive here early in March.

Their cry is a wheezy squeak and their call a rasping chirp.

These birds do a great deal of mischief in cornfields, but partly make up for the injury they do by destroying rose bugs, curculio, May beetles, grasshoppers, crickets and locusts.

Grebe, Holboell's.-This is the largest of the Grebes and is very seldom seen in New Jersey, occurring occasionally during migrations. It is nineteen inches in length; bill, two inches; the upper parts are of a dull black and the under of a silvery white, generally with more or less rusty red on the neck, except in young birds. Grebes nest among the rushes and reeds, and the nest, composed of a mass of decayed vegetation, is frequently seen floating in the water.

Grebe, Horned.-Length, thirteen inches; bill, threequarters of an inch; above, glossy black, tinged with gray; head with tufts of feathers which project on each side 
like a hood, glossy, greenish black, a stripe on each side of the head passing through the eye, reddish buff; under parts silky white; neck, breast and sides of body; reddish chestnut; young birds are plain, dull black above and silky white below. It is somewhat more numerous in New Jersey than the preceding, especially during migrations, occurring from November until May.

\section{Grebe, Pied-billed, Dabchick, Diedapper, Hell-} Diver or Water Witch. - This is the most common of the Grebes; remaining in New Jersey for fully nine months in the year; from its appearance at a distance and its habits it is frequently mistaken for a duck and in fact in a few places it is referred to as the Hen-bill Duck. It is a little over thirteen inches in length. It obtains one of its'names from the fact that the bill, about ninetenths of an inch in length, is shaped like that of a chicken; it is dull white in color, crossed with a black band. Its throat is black; back, glossy black; under parts, silky white, mottled with brown and black; fore breast, rusty brown and black; wings, brown, slightly tipped with white. Tail represented by a few soft, downy feathers, scarcely perceptible.

The nest is built like that of Holboell's Grebe; the floating mass is held together by mud and moss and the eggs are frequentloy concealed by a thin layer of similar muck. The eggs are from four to eight in number, of a dirty white, one and three-fourths by one and one-fifth inches in size.

It breeds throughout the whole of North America, with the exception of the extreme north and south, going as far south as South America during the winter. Some remain in New Jersey throughout the whole year, but it is not a common breeder.

Its food consists of frogs, insects, lizards and the seeds of grasses.

Grosbeak, Cardinal. See Cardinal Bird. 
Crosbeak, Rose-breasted.-Length, eight and onehalf inches; extent, thirteen inches. Above, jet black, except the rump, which is white; wings, black barred and tipped with white; tail, black; the three outer feathers with the inner webs largely white; side of head and fore neck, black; breast, brilliant rosy pink; rest of under surface, white; underneath the wing a patch of rose pink feathers. Younger birds have more or less dull brown feathers in the wing and tail. In autumn the plumage is quite different. The bird then appears brown above, streaked with black; wings barred and tipped with white, and dull white line over the eye; below, buff, speckled with black, with throat and breast more or less suffused with pink, and pink feathers under the wing. The female at all seasons resembles the autumn plumage just described, but has less buff beneath and no pink; beneath the wing the feathers are yellow. The bill is very thick and nearly pure white in the spring male, more dusky in the female; legs and feet, blue gray.

The nest is found in bushes or trees, from five to twenty feet from the ground. It is a perfect circle, made of fine twigs, weeds and roots, and lined with the same but of a finer quality. The eggs are from four to five in number, nine-tenths by seven-tenths of an inch in size, and of a pale blue with olive-brown markings.

It breeds in the northern part of the United States and in Canada, but is found during the summer only in the northern portion of New Jersey; migrants arrive in the state during the first part of May and those that go further north return in September.

The song is frequently heard towards evening and is a delightful warble, somewhat resembling the robin's, but more exquisitely pure.

Its fondness for potato-bugs has earned for it in some localities the name of Potato-bug Bird, but it also destroys beetles, bugs and larvae. Its vegetable food con- 


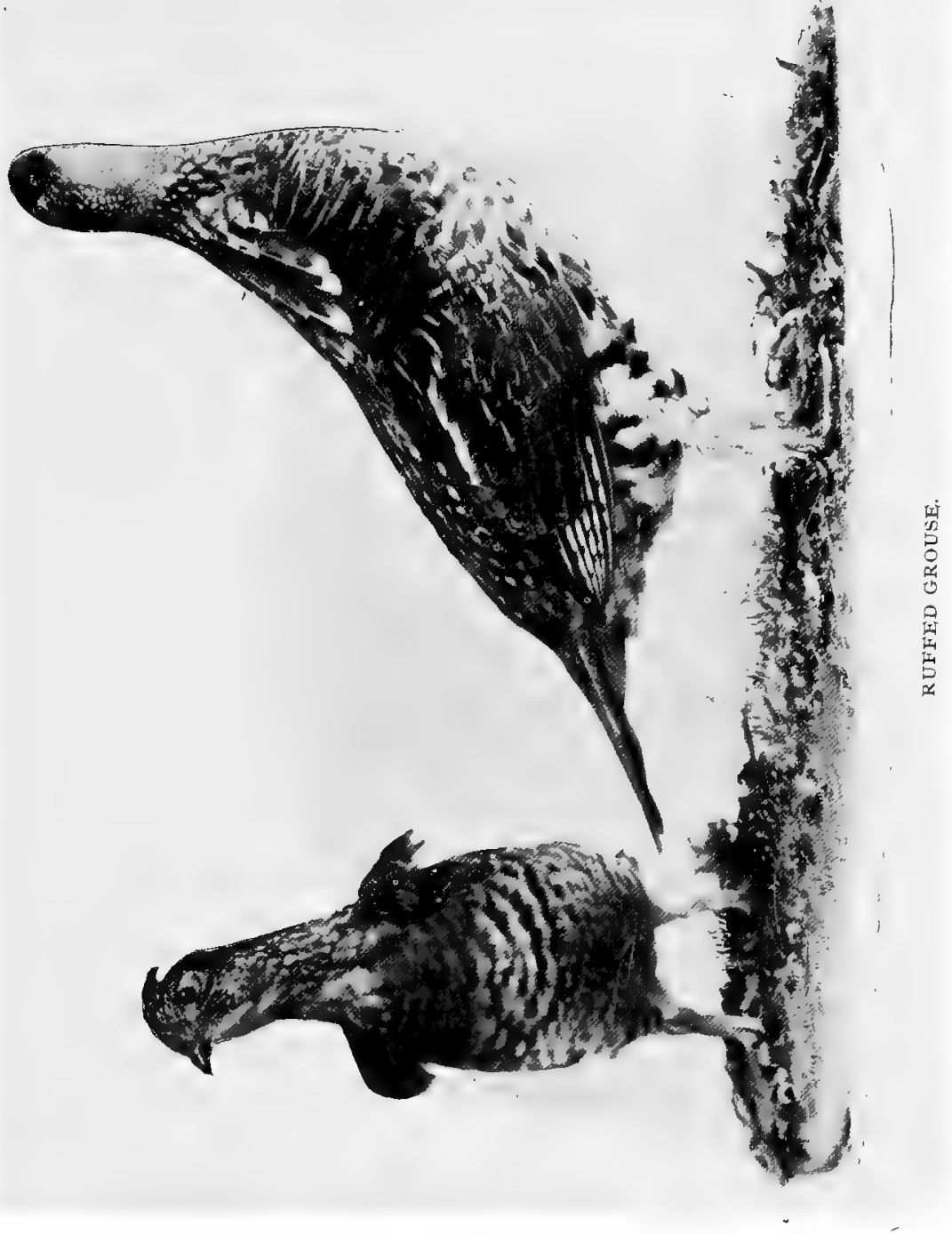



sists of the buds of the hickory, beech and birch, and also fruit blossoms.

Grouse, Ruffed, Partridge or Pheasant.-Length, eighteen inches; extent, twenty-three inches; bill, half an inch, horn color. Plumage above, reddish brown, most of the feathers with buff central stripes and finely mottled with black and gray; neck with a tuft of broad ended black feathers which project beyond the rest of the plumage and are erectile at will; upper surface of wings like the back; the long outer feathers dull brown, with light spots on their edges; tail, rusty brown, transversely mottled with black, and with broad terminal black and gray bands; under surface white, becoming buff on the breast and throat, and transversely barred with brown, except on the throat and center of he body; flanks with broad black bars. Female similar, but with the neck . tufts rudimentary or wanting. In southern New Jersey this bird is commonly called a pheasant, while the name partridge prevails in the northern part of the state.

The nest is built in April of leaves and grass on the ground, in underbrush or at the base of the stump of a tree or the side of a log. The eggs are from eight to fourteen in number, of a pale brownish yellow, one and a half by one and one-tenth inches in size.

The birds breed in the eastern United States as far south as Georgia and remain all year.

The male is in the habit of drumming on logs and fallen trees and the cry of the bird is a rup-rup-rup-rup-r-r$r-r-r$.

The food of the bird consists of berries and insects, principally ants; in the fall, also seeds and chestnuts; in the winter leaves, and in the spring buds.

Gull, Black-Headed.-See Laughing Gull.

Gull, Black-Headed, or Saddleback.-Length, twenty-nine inches; bill, two and a half inches; head and 
neck white, somewhat streaked with dusky; back, dark slate, darker than any of our other gulls; rump and tail, pure white, as well as the entire under part; long wing feathers black with white tips.

The nest is built on the ground, of grasses and seaweed; the eggs are three by two and one-fourth inches in size, of a dirty white with brown spots, and either two or three in number. Its breeding location is the North $\mathrm{Al}$ lantic coast and it winters southward as far as New Jersey, though the bulk do not come quite so far south.

Gall, Bomaparte's. - Length, fourteen inches; bill, one and one-tenth inches, black; head, white, tinged with gray, with dark spots over the ear; back, pearl gray; three outer wing feathers mostly white; the outermost black externally, all the long wing feathers black on their terminal portion; rump and tail and under parts pure white. In summer the heads become very dark gray while the young birds have a terminal black band on the tail.

The nest is built on stumps or in bushes or trees; it is made of sticks, lined with grass. The eggs are two inches by one and two-fifths in size, of an olive color, with greenish tint, and three or four in number. The bird breeds in the far north and spends the winter in the West Indies and Mexico and as far south as South America; in New Jersey it is transient during migrations but not very common. It adds to the usual marine food gathered by gulls from the surface of the water, insects and beetles.

Gull, Herring, or Winter Gull.-Length, twentyfour inches; bill, two inches and a quarter, yellow with a bright red spot; head, white, sometimes streaked with dusky; back, pearl gray; rump and tail and entire under surface of the body white; long wing feathers black for their terminal portion, tipped with white. Young birds have the wings and tail brownish, and the whole plum- 
age above and below mottled with brownish graiy and white.

It builds a nest in a hollow in the ground; it is made of grass and seaweed." The eggs are three inches by two, of a gray brown with dark brown spots, two or three in number. It breeds on the Atlantic coast as far south as New England and in the winter goes as far south as the West Indies. It is abundant in New Jersey, on the coast and in large rivers, from October to April. It acts as a scavenger for both ocean and rivers, picking up offal and dead fish from the surface of the water.

Gull, Laughing, or Black-headed Gull.-Length, sixteen inches; extent, three feet six inches; bill, one and a half inches; head, very dark slate, with a white spot above and below the eye; neck, pure white, all around; back and wings, lead gray; rump, tail and under parts white, the latter with a delicate rose flush in the living bird; long wing feathers black terminally; feet and bill, deep carmine. In winter the head is white, while the young birds have the head and neck mottled and a terminal black band on the tail.

It builds its nest on the ground in marshes, of grass and seaweed. The eggs are two and one-tenth by one and a half inches in size, a brown or dark olive in color, with dark brown spots and splashes, and from three to five in number. It breeds along the Atlantic coast southward from New England and goes as far south as the West Indies and South America in winter. Il, is a resident in New Jersey, from May to October, but is becoming rare. Its cry resembles a long peal of laughter, a haw-ha-ha-ha-haw.

Gull, Ring-billed.-Length, nineteen inches; bill, an inch and a half, greenish yellow, with a distinct black band near the tip; plumage almost as in the Herring Gull; young as in the Herring Gull, mottled with brown, gray 
and white, with the tail dusky, except at base; feet, pale yellow.

Its nest, of seaweed and grasses, is built on the ground; the eggs are two and one-fourth by one and three-fifths inches in size, of a dirty white, with brown spots, and either two or three in number. It breeds in the far north and in winter goes as far south as Cuba. It is tolerably common along the New Jersey coast from October to May.

Gull, Wointer. See Herring Gull.

Hagdon, Black. See Sooty Shearwater.

Hairbird. See Chipping Sparrow.

Hangmest. See Baltimore Oriole.

Harrier. See Marsh Hawk.

Hawk, Imerican Rough-legged or Black Hawk. -Length, twenty-two inches; back, black, slightly mottled with buff and white; head, much more streaked with white; wings, brown, basal portion of long feathers, white, inner ones somewhat barred; tail, white, at base dusky, on the terminal portion forming indistinct bars; rump and feathers covering the base of the tail, mottled; beneath, throat, neck and breast buffy white, longitudinally streaked with brown; stripes broader on the breast; lower abdomen uniform black or very dark brown; thighs buff, mottled with brown. Some individuals have more black in the plumage, occasionally reaching an almost uniform black coloration. This Hawk can be distinguished from all others by the feathering of the legs, which extends to the base of the toes.

It nests on rocky ledges or in trees. The eggs are two and one-fifth by one and three-fourths inches in size, of a dirty white, sometimes spotted with brown and from two to five in number. 
It breeds north of the United States and in winter goes southward to the Middle States. It is a rather rare visitant in New Jersey, being occasionally met with, principally in marshes near large streams, from November to April.

Government examination of 49 stomachs showed that 40 contained mice, 5 other mammals, 1] lizard, 1 insects and 4 were empty.

Mawk, Broad-winged,--Length; sixteen inches; extent, thirty-four inches; back and upper surface of wings, dark brown, slightly mottled with gray; feathers on the back of the head with pure white bases and long wing feathers white on their basal portion; tail, very dark brown with two whitish bands and a narrow terminal band; throat, white, streaked longitudinally with brown; rest of under surface white, transversely banded with brown, bands on the breast often joining and divining the white into roundish spots. Young birds are tinged with buff below and are streaked longitudinally with brown over the whole lower surface.

It nests in trees at a considerable distance from the ground. The eggs are two and one-fifth by one and three-fifths inches in size, yellowish with brown spots and from two to four in number.

It breeds throughout the Eastern United States and in winter goes south as far as South America. It is a not very common resident in New Jersey.

Government examinations of 65 stomachs showed that 2 contained small birds, 15 mice, 13 other mammals, 11 reptiles, 13 frogs and similar animals, 30 insects, 2 earthworms, 4 crawfish and 7 were empty.

Hawk, Chicken. See Red-tailed Hawk, Red-Shouldered Hawk and Cooper's Hawk.

Hawk, Cooper's, or Chicken Hawk--Length, eighteen inches; extent, thirty inches; above, slate color, 
slightly mottled with white; long wing feathers barred with dusky on the terminal portion, white at the base; tail, grayish brown, with four dusky bands; below, white, transversely barred with rusty and all the feathers with dusky shaft lines; flanks, rusty. The young bird is brown above and white beneath, longitudinally streaked with brown. It nests in April or May, in thick woods, generally in evergreens or hickories, from twenty-five to fifty feet from the ground; the nest is composed of sticks, moss, leaves and grass. The eggs are from three to six in number, two by one and a half inches in size, of a pale bluish white, sometimes lightly spotted with red.

It breeds and is distributed over the whole of temperate North America.

Cooper's Hawk is a very destructive bird, and the only one of our Hawks which is not beneficial to the farmer. All the others live mainly on mice and insects and but rarely visit the poultry yard. Government examination of 64 stomachs showed that 15 contained poultry or game birds, 17 other birds, 1 mice, 1 frog, 1 lizard, 2 insects, 11 were empty. Government examination of 133 stomachs showed that 34 contained poultry or game birds, 52 other birds, 11 mammals, 1 frog, 3 lizards, 2 insects and 39 were empty.

Hawk, Duck, or Falcon.-Length, sixteen to twenty inches; extent, three feet; above, sooty back; feathers more or less edged with rusty; back of neck lighter, generally buff streaked with brown; wings, brownish black, barred on the inner webs with buff or cinnamon; tail similar, with a whitish tip; under side of body dull white or buff, longitudinally streaked with brown; old birds have the fore breast nearly or quite devoid of streaks.

It nests in hollow trees and on rocky cliffs. The eggs are two inches by one and three-fourths inches in size, of a dirty white to a light brown, with darker spots of the same color, and either three or four in number. 


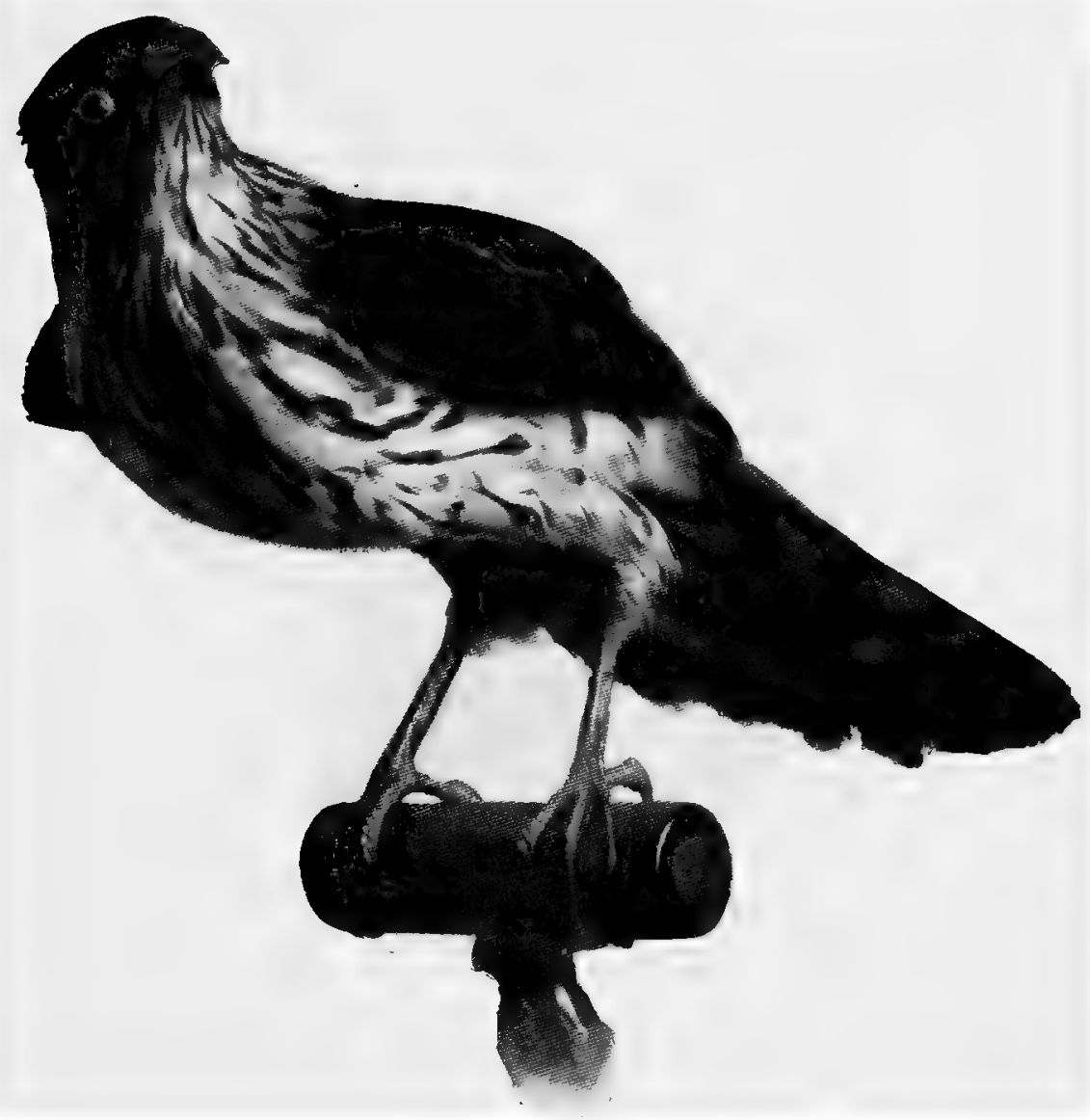

COOPER'S HAWK. 

It breeds in North America southward as far as the Middle States. In New Jersey it is more frequent in winter, rather common along the coast, where it preys on water birds, but rather scarce in the interior. A few breed along the upper Delaware.

Government examination of 20 stomachs showed that 7 contained poultry or game birds, 9 other birds, 1 mice, 2 insects and 4 were empty.

Hawk, Fish. See Osprey.

Hawk, Hen. See Red-shouldered Hawk, Red-Tailed Hawk and Cooper's Hawk.

Hawk, Marsh, or Harrier.-Length, eighteen to twenty inches; male, above light bluish gray, as is also the whole head and fore part of the breast; rest of under surface white, sometimes spotted with rusty; tail, gray, barred with broad black bands, and a little rufous near the base; inner webs of wing feathers white at base; female, brown above, mottled with rusty edgings on the head; under parts, rusty, shaded and striped with brown on throat and breast; tail brown, with blackish bands; inner webs of wing feathers barred brown and white; young birds similar to female.

This bird at all times and in intermediate plumages can be easily identified by the pure white rump.

The nest is built on the ground in a marsh, near water, at the base of a bush or in the top of a tussock, composed of dry grass and dead twigs with a spare lining of feathers. In New Jersey mating begins in June. The eggs are from four to six in number, rarely as many as eight, of a dull white, sometimes with brown blotches, one and three quarters by one and two-fifths inches in size.

The breeding location is the whole of North America to Alaska. 'I'he birds are resident in New Jersey, but are much more plentiful in winter.

The food of this bird consists principally of meadow 
mice and ground squirrels, although it also takes young squirrels, lizards, frogs, snakes, insects, birds and when hungry partridges, plover and barnyard fowl. Dr. A. K. Fisher, in the report of the Ornithologist and Mammalogist of the United States for 1889, says of this bird: "Of 124 stomachs examined, 7 contained poultry or game birds, 34 other birds, $5 \tau$ mice, 22 other mammals, $\tau$ reptiles, 3 frogs, 14 insects, 1 indeterminate matter and 8 were empty. Although this Hawk occasionally carries off poultry and game birds its economic value as a destroyer of mammal pests is so great that its slight irregularities should be pardoned. Unfortunately, however, the farmer and sportsman shoot it down at sight, regardless or ignorant of the fact that it preserves an immense quantity of grain, thousands of fruit trees and innumerable nests of game birds by destroying the vermin which eat the grain, girdle the trees and devour the eggs and the young of birds. The Marsh Hawk is unquestionably the most beneficial as it is one of our most abundant hawks, and its presence and increase should be encouraged in every way possible, not only by protecting it by law, but by disseminating a knowledge of the benefits it confers. It is probably the most active and determined foe of meadow mice and ground squirrels, destroying greater numbers of these pests than any other species, and this fact alone should entitle it to protection, even if it destroyed no other injurious animals."

M awk, Pigeon.-Length, ten inches; above, bluish slate color, each feather with a black shaft streak; tail, black with three slate colored bands and narrowly tipped with white; long wing feathers black, transversely banded with white (very noticeable from beneath); under side of body white, tinged with buff, especially on the flanks, and everywhere longitudinally streaked with black. Female differs in being brown above and buff beneath, with the bars on wings and tail buff instead of white. 


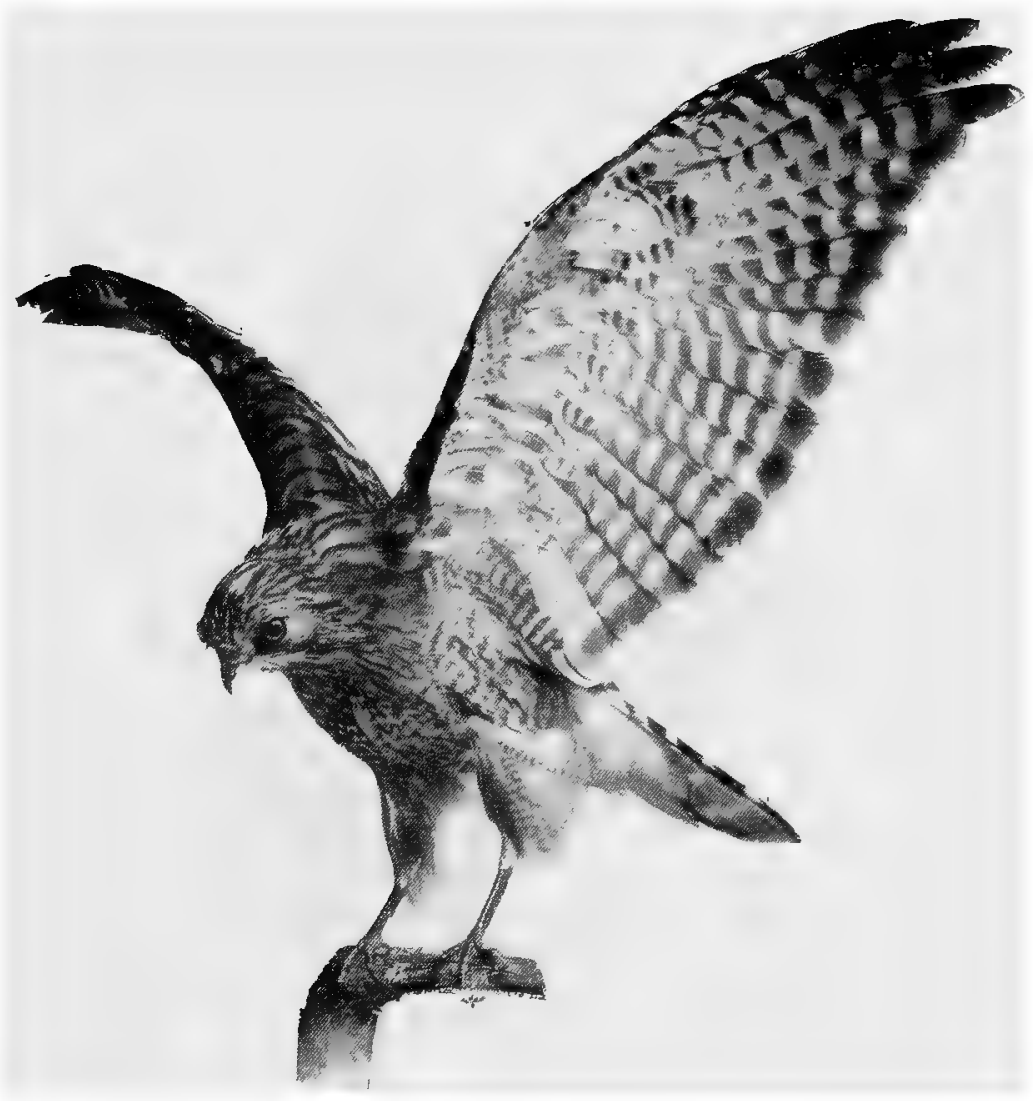

RED-SHOUIDEREDD HAWK. 
The Pigeon Hawk is in appearance a miniature of the Duck Hawk. It occurs in New Jersey during the migrations and in winter, but breeds farther north. Though not very generally distributed, it is sometimes quite common along the coast.

Hawk, Night, Night-jar or Bull-bat.-Length, nine and a half inches; extent, twenty-three inches; the female is a trifle smaller; the upper parts are of a very deep blackish brown, thickly speckled or powdered on the back and head with innumerable minute spots and streaks of a pale cream color, interspersed with specks of reddish; the tail is barred with the same for about twothirds of its length, the terminal third being black, with a broad white band about three-quarters of an inch from the tip, the two middle, however, lack the white bar near the tips; a triangular spot of white marks the throat; the bill is small, less than a fourth of an inch in length, and of a black color; the mouth, however, is very large - and the gape reaches back below the eye; the legs are very short, and of a purplish flesh color, seamed with white; the claw of the middle toe is long and peculiarly serrated; the whole lower parts of the body are marked with transverse lines of dusky and yellowish; the wings are dark brown with a broad bar of white across the five outer feathers; they are very long and slender and when closed reach beyond the tip of the tail. The female differs in having no white band on the tail, while the triangular spot of white on the throat is replaced by a dully defined mark of a reddish cream color. During the daytime these birds roost lengthwise on a limb, instead of crosswise as most birds do. They are easily recognized at sunset or at night by their erratic flight.

The Night Hawk builds no nest whatever, simply depositing, about the middle of May, its eggs on the bare ground or on a rock in the open field, occasionally on the roof of a house. The eggs are two in number, of a dirty bluish 
white, with irregular specks and blotches of brownish gray or grayish brown; they are oblong, being equally thick at both ends, and one and one-fifth by four-fifths of an inch in size.

The birds spread themselves over the whole of Eastern North America, arriving from the West Indies and Mexico about the first of May and returning about the middle of October.

Their cry is a squeak, peent, uttered either singly or in rapid succession; as they swoop down, frequently eighty or a hundred feet, and then sail off, they make a noise like the blowing into the bunghole of a hogshead.

Their food consists of wasps, beetles, flies and the larger insects; they are very fond of crickets.

The name "Hawk" is entirely a misnomer, as the bird is in no way related to the Hawks, its nearest relative being the Whip-poor-will, a species with which it is often confused, though they are quite distinct.

\section{Hawk, Red-Shouldered, Hen Hawk or Chicken} Hawk.-Length, eighteen inches; extent, three feet; above, brown, the feathers edged with rusty and sparingly spotted with white; wing feathers dark brown, spotted on the outer webs with white; inner webs on basal portion white, barred with brown; tail, dark brown, with four narrow white bars and a dull white tip. Under surface transversely barred with rusty and white, sometimes with a few longitudinal brown stripes. Young birds are brown above with slight white mottling; below, white, streaked all over with oval longitudinal spots; tail, dark brown, with five or six buff bars becoming indistinct toward the tip.

The nest is buiit in April or May in trees thirty to sixty feet from the ground, composed of a foundation of sticks with an upper story of soft bark. The eggs are from three to six in number, two and one-fifth inches by one and three-fifths, of a dull white color with brown spots. 


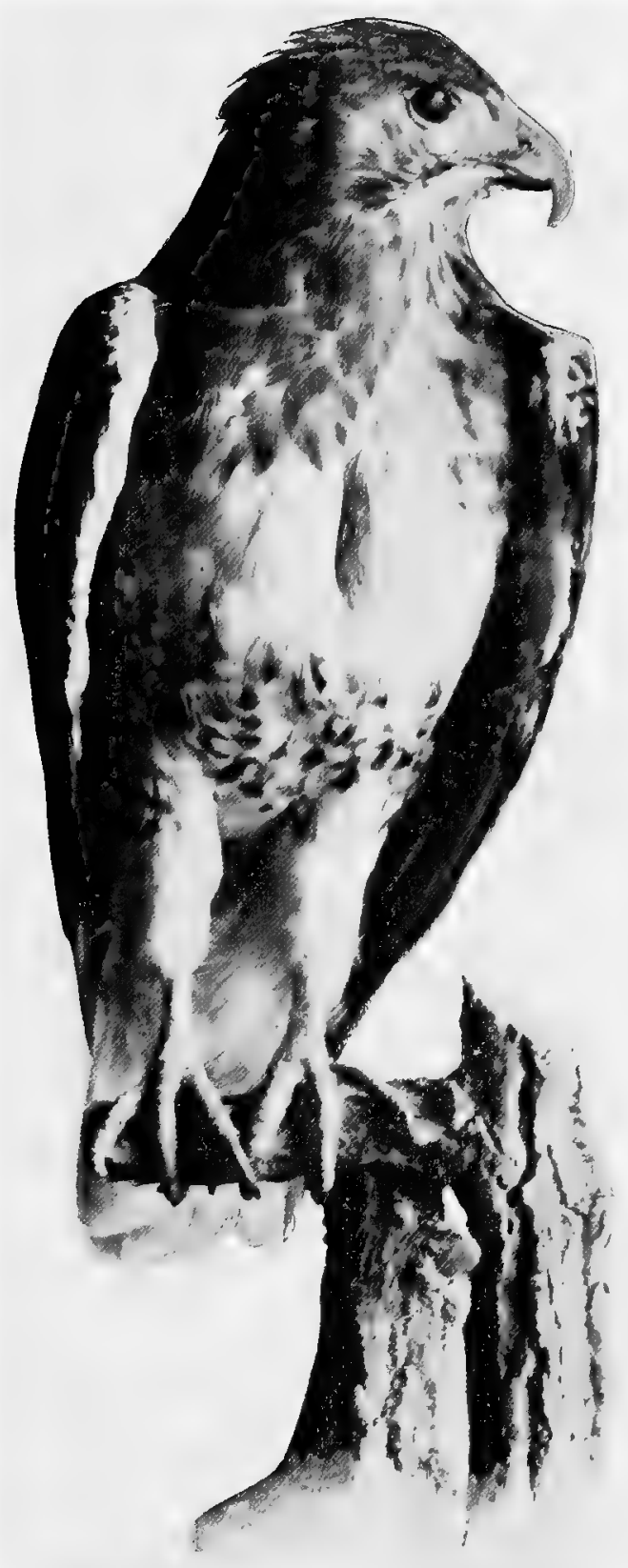

RED-TAILED HAWK. 

The birds breed and are distributed over the whole of North America to Nova Scotia and Manitoba.

Government reports of examination of 102 stomachs showed that 1 contained poultry, 5 other birds; 61 mice, 20 other mammals, 15 reptiles and frogs, 40 insects, 7 spiders, 3 crawfish, 1 earthworm, 1 offal, 1 catfish, 3 were empty. Government examination of 220 stomachs showed that 3 contained poultry, 12 other birds, 102 mice, 40 other mammals; 10 reptiles, 39 frogs, 92 insects, 16 spiders, 7 crawfish, 1 earthworm, 2 offal, 3 fish, 14 were empty.

\section{Hawk, Red-tailed, Hen Hawk or Chicken Hawk.}

-Length, twenty inches; extent, three feet, nine inches; above brown, with slight mottling of white and gray; lower parts pure white, with brown streaks on the belly and flanks; wing feathers brown, somewhat barred towards the tip; inner webs, white at their base; tail, uniform rufous, with a narrow black bar near the tip (sometimes plain); young with tail brown, with nine or ten narrow blackish bars. In this plumage it greatly resembles the young of the Red-shouldered Hawk, but can be distinguished by the absence of streaks on the center of the breast and neck.

The nest, built in trees, thirty to seventy feet from the ground, is composed of sticks surmounted by a layer of soft bark. Mating begins in March. The eggs are from two to four in number, two and two-fifths inches by one and four-fifths in size, of a dull white, thickly blotched with shades of brown.

The bird breeds and is distributed throughout the eastern part of North America.

Government examination of 311 stomachs showed that 29 contained poultry or game birds, 35 other birds, 203 mice, 55 other mammals, 9 reptiles, 24 insects, 3 craw. fish, 4 offal, 29 were empty; 210 stomachs contained 270 mice. An examination of 562 stomachs showed that 54 
contained poultry and game birds, 51 other birds, 278 mice, 131 other mammals, 27 reptiles, 47 insects, $8 \mathrm{craw}$ fish, 1 centipede, 13 offal, 89 were empty.

Hawk, Sharp-shinned.-This bird at all stages is like the Cooper's Hawk in plumage, and is, in fact, a miniature of it. The sexes are alike in color. The nest is built in trees from fifteen to forty feet from the ground, but occasionally on a rocky ledge. It is built of sticks as a foundation for an upper story of bark, leaves and moss. Mating begins in April. The eggs are from three to six in number, one and a half by one and onefifth inches in size, of a bluish white to a pale cream buff, spotted and at times washed with chocolate, occasionally with $a^{\circ}$ wreath of chocolate blotches at the large end.

The bird breeds over the whole of the United States, and occurs at all seasons in New Jersey, going also as far south as Guatemala in winter.

The Sharp-shinned Hawk is very destructive to our smaller birds and has but few redeeming features. Government analysis of 48 stomachs showed that 2 contained poultry and game birds, 35 other birds, 4 rnice, 2 insects, 10 were empty. Examination of 159 stomachs showed that 6 contained poultry and game birds, 99 other birds, 6 mice, 5 insects, 52 were empty.

Hawk, Sparrow.-Length, ten inches; extent, twenty inches; female about an inch longer; head, blue gray with a central patch of rusty; side of face white, with three vertical black bars, one from the base of the bill, one across the ear, and one on the neck; whole back and sides of the neck rusty red, with a few transverse black marks on the center of the back; wings gray, long feathers black on the outer webs, black and white on the inner; tail with the two outer feathers barred black and white, others mainly rusty, all with a terminal black band and a 


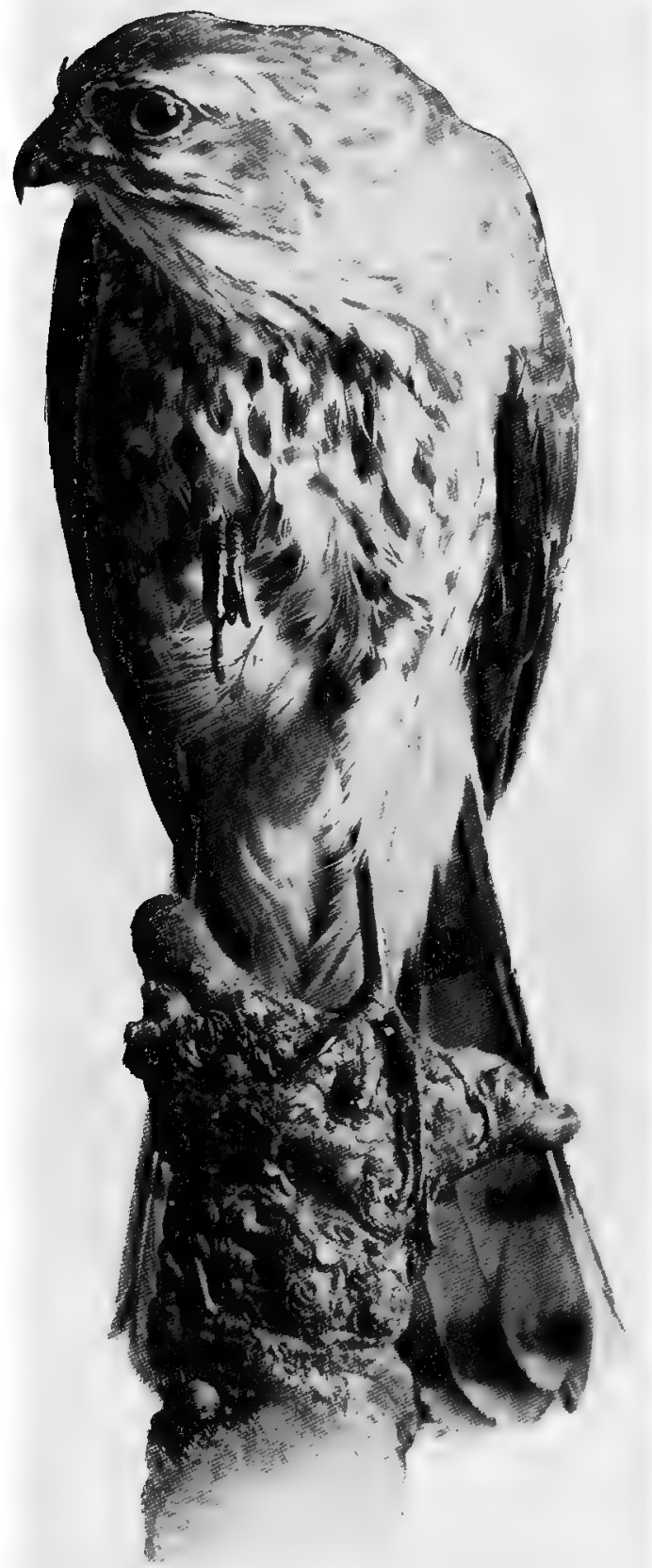

SHARP-SHINNED HAWK 

white tip; under surface white, tinged with rusty on the breast and spotted with black on the sides. Female, back and tail transversely barred with black and rusty; lower surface, white, whoie breast longitudinally streaked with brown; head as in the male.

The bird nests in hollow trees, twenty feet or more from the ground, sometimes in woodpeckers' holes or in dove cotes. Mating begins about the middle of May. The eggs are from three to seven in number, of a creamy to a light brown, one and two-fifths by one and one-fifth inches in size.

It breeds throughout temperate North America and in winter goes as far south as South America. It occurs in New Jersey at all seasons. It has a peculiar cry, somewhat resembling killy-killy-killy-killy.

The food of the Sparrow Hawk consists principally of grasshoppers and other noxious insects; in the fall it destroys Sparrows and other small birds. Government examination of 133 stomachs showed that 1 contained a game bird, 28 other birds, 55 mice, 6 other mammals, 5 reptiles, 83 insects, 12 spiders and 5 were empty. Examination of $3: 0$ stomachs showed that 1 contained a game bird, 53 other birds, 89 mice, 12 other mammals, 12 reptiles, 215 insects, 29 spiders, 23 were empty. In 158 stomachs were found 31 birds, 79 mice and other mammals, 8 reptiles and 1,125 insects.

Hell-Diver. See Pied-billed Grebe.

Heron, Great Blue, or Blue Crame.-Length, from forty-two to fifty inches; extent, six feet; bill, four and a half to six and one-fourth inches; head, with drooping crest of black and white; back, slaty gray; breast, black and white, almost covered with tufts of feathers from the neck; belly, a deep blackish slate; sides, blue ash; tail, slaty gray; wings, slaty gray; legs and feet, black. The young are much streaked with rufous below. 
The nest is a flat and rude contrivance made of sticks and placed in trees; the birds generally roost and breed in colonies. The eggs are oblong, two and a half by one and a half inches in size, of a pale bluish green color and either four or five in number.

The birds breed from Hudson's Bay southward and most of them spend the winter south of the Middle States. They are common in New Jersey, from the first of April to the middle of November, being most plentiful along the coast in Septemberand are seen occasionally in midwinter. There are still several colonies nesting yearly in the swamps of southern New Jersey.

The bird depends principally on fish for food, but also devours frogs, reptiles, meadow mice, dragon flies, grasshoppers and other insects.

Herom, Green, or Poke.-Length, seventeen inches; extent, twenty-five inches; bill, two inches long; top of head with pendent crest, metallic green; back and sides of neck, chestnut, varying to maroon; chin, white; throat, streaked with black and white; back and upper side of wings and tail, metallic green, centre of back covered with long, narrow somewhat glaucous feathers with white shaft lines, and many of the wing feathers narrowly edged with buff; under parts, plain gray; young birds more or less streaked with buff and rusty.

The nest is built in a bush or low tree, being a rude and flat contrivance. The eggs are from three to six in number, of a pale greenish blue, one and a half inches by one and one-tenth in size. They breed throughout temperate North America, as far north as Ontario. They are found both along the coast and in the interior of New Jersey, from about the first of April to the first of October. In winter they migrate to South America.

The birds feed generally at dawn and dusk on fish, frogs and insects.

Herom, Might, Quawk or Qua-bird,-Length, 
twenty-six inches; extent, four feet; head, greenish llack, except a small white patch across the forshead; from the back of the head come several long thread-like white feathers, six or eight inches long, which hang down over the neck; back and innermost wing feathers, dark bottle green; wings, rump and.tail, ashy gray; entire neck and under surface light gray, varying to white on the throat; legs, yellowish green; bill, black, two inches and threequarters long; female indistinguishable from male. Young birds are entirely different. Plumage, above, brown streaked with blackish and rufous buff; tail, gray; wings, grayish brown, with rusty edgings and buff spots; Under parts streaked longitudinally with brown, white and buff.

The nest is built in the tops of trees, being a large contrivance made of sticks; the eggs are from four to five in number, of a dull blue, two inches by one and three-fifths in size. The birds breed in the whole of North America, the extreme north excepted. In the winter they migrate south to the Middle States. They arrive in New Jersey about the end of April and leave about the middle of October; they are generally found in the marshes and on the rivers inland and are scarce on the coast.

The name of the Qua-bird is derived from an unpleasant noise they make greatly resembling retching.

They depend almost wholly on small fish for food and feed at night.

Heron, Snowy. See White Egret.

High-hole. See Flicker.

Hoodlum. See English Sparrow.

Homming-bird, Ruby-throated.-Length, three and a half inches; extent, four and a quarter inches; bill, three-fourths of an inch. The whole back, upper parts of the neck and sides under the wings are of a rich metal- 
lic golden green; the tail is forked and as well as the wings of a deep brownish purple; bill and eyes, black; legs and feet, both of which are extremely small, black; the bill is straight and very slender; belly, a dusky white, mixed with green. The chief ornament of this little bird is the splendor of the feathers of its throat which when placed at the proper angle glow with all the brilliancy of the ruby. These feathers are of singular strength and texture, lying close together like scales, and vary when moved before the eye from a deep black to a fiery crimson and burning orange. The female is destitute of this ornament; her tail is tipped with white and the whole lower parts are of the same tint. The young birds of the first season have the tail tipped with white and the whole lower parts nearly white with a few streaks of ruby tints on the throat.

The nest is about an inch and a half in diameter, built on the limb of a tree, seldom more than ten feet from the ground. The exterior part is made of lichens matching the color of the branch on which it is situated; the interior is made of plant down and the two are tightly woven together with almost invisible plant fibres. It is built shortly after the first of May. The eggs are two in number, white, one-half by three-tenths of an inch in size. The birds arrive in New Jersey from the south early in May and leave about the end of September.

As they fly through the air they make a humming noise caused by the rapid vibration of their wings.

Their cry is a mouse-like squeak.

They feed on small insects and on honey, gathering the latter from flowers.

Indigo-bird, or Indigo Bunting.-Length, five and one-half inches; bill, two-fifths of an inch, bluish horn color; plumage, above and below, brilliant blue, deeper and inclining to purple on the head; wings and tail, blackish, with blue edgings; younger birds often show a 
few brown feathers on the body or in the wings; female, reddish brown above, with a tinge of blue on the shoulders and rump; below, dull white, streaked with dusky on the throat, breast and sides. Males in fall and winter resemble the females, but the bases to all the feathers are blue. Young birds of both sexes resemble the female for the first year, but are much more suffused with rusty.

The nest is very compact and cleverly hidden in the crotch of a bush near the ground; it is made of grasses, leaves and bark, lined with hair and fine grasses. The eggs are three or four in number, of a pale bluish white, three-fourths of an inch by half an inch in size. It breeds in the eastern United States as far north as Canada and in the winter migrates to South America. It appears in New Jersey shortly after the first of May and leaves about the first of October.

Its song, which lasts until late in August, when most birds are silent, is strong but shrill, sounding something like che-che-che-chay.

It feeds on the ground on small grasses and herbs.

Jack Curlew. See Hudsonian Curlew.

Jar. See Night Hawk.

Jay, Blue. See Bluejay.

Joree. See Chewink.

Junco. See Snowbird.

Killdeer, or Killdeer Plover.-Length, ten inches; extent, twenty inches. The bill, three-fourths of an inch in length, is black; above, grayish brown, a white and black collar on hind neck; rump, rusty; wings, dusky, with white shaft streaks on the long feathers near their tips and a white bar across the middle of the wing; center tail feathers gray, others rusty, terminal half crossed by a 
broad black band, tips of feathers white; across the forehead, a black and white band, and a dusky stripe from the bill to the eye; below, white, with two black bands across the breast; legs and feet, a pale light clay color; exterior toe joined by a membrane to the middle one as far as the first joint.

The nest is merely a depression in the ground, sometimes lined with grass. The birds breed from April until June. The eggs, four in number, are very much pointed at one end, one and a half by one and one-eighth inches in size, of either a cream or brownish drab and covered thickly with spots of a blackish brown.

They breed throughout temperate North America, arriving in New Jersey about March 20 from the southern United States and leaving the latter part of October, although a few winter in the lower part of the state.

Their cry is kill-dee, kill-dee, repeating the latter syllable a number of times rapidly when flushed.

Their food consists of worms, insects, larvae, small crustacea and they are frequently seen running over recently ploughed ground looking for insects.

\section{Kingbird, Tyrant Fycatcher, or Bee Martin.} -Length, eight inches; extent, fourteen inches; above, dark slate, blackish on the head; wings and tail, black, the former edged and the latter tipped with white; body below, pure white, tinged across the breast with gray; the plumage on the crown, although not forming a crest, is frequently erected, and discovers a rich bed of brilliant orange or flame color; when the feathers lie close this is altogether concealed; the bill is half an inch in length, very broad at the base, of a glossy black color and furnished with bristles at the base; the legs and feet are black, seamed with gray. The female differs in being more brownish on the upper parts, has a smaller streak of paler orange on the crown and a narrower border of duller white on the tail. The young birds do not receive the orange on the head during the first season. 


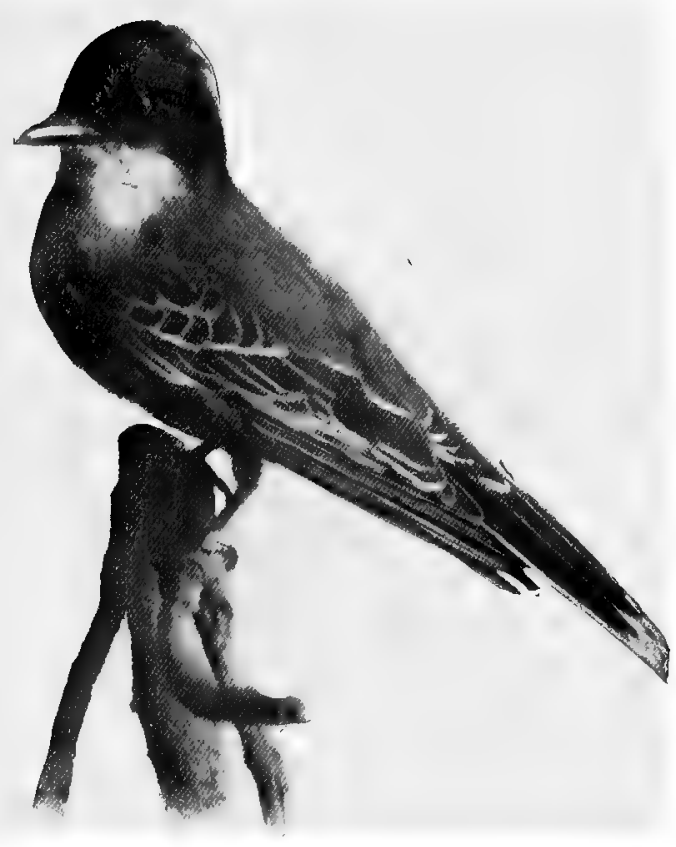

KINGBIRD. 
The nest is built about the first of May on the extreme end of a branch, in thin woods or orchards, some twenty feet from the ground. It is a bulky contrivance, made of weed stalks and grasses and lined within with plant down. The eggs are from three to five in number, white, spotted with amber, almost round, and one by threefourths of an inch in size.

The birds spread themselves from the south over the eastern United States, arriving here about the first of May and leaving about the first of September. Large flocks are frequently seen in southern New Jersey in August.

Their cry is a shrill twitter, somewhat resembling $k-y$ rie, several times repeated.

For a long time the food of this bird was a matter of dispute and it was supposed that it fed to a great extent on bees. Government examination of 218 stomachs showed that ninety per cent. contained insects and in only fourteen were there found any traces of bees and in the majority of these cases the traces were those of drones. Among the insects were found large numbers of the robber fly, an insect which frequently kills a hundred bees in one day. There were also found large numbers of gad-flies, well known as pests of cattle, and a large proportion of grasshoppers. Of the fruit eaten by the Kingbird only three or four kinds are cultivated, the bird feeding, as far as vegetable diet is concerned, principally on wild cherries, elderberries, mulberries, wild grapes, sassafras, buckthorn and other wild fruit.

Kingfisher.-Length, twelve and a half inches; extent, twenty inches; general color above, blue slate; feathers of the head long and pointed, forming a conspicuous crest, bluish slate, centered with black; the inner tail feathers have an irregular black stripe down the middle, the rest are black, with slaty blue edges, all are more or less spotted with white; long: wing feathers, 
black, with the basal portion white and a few white spots on some of the outer webs; color of under surface of the body, white, with a broad slaty blue band across the breast, while the sides of the body are slaty with white bars; the white of the throat extends around on the back of the neck, forming a more or less complete collar, and there is a white spot in front of the eye and another just below it; some individuals have white dots on the upper surface of the wings, and in certain plumages the slaty breast band is suffused with rusty; the bill is two inches long, strong, sharp-pointed, and black, excepting near the base of the lower part of tip, where it is of a horn color; the wings are marked with small specks of white; legs, extremely short, of a dirty yellow color, above the knee bare of feathers for half an inch; the two exterior toes are united together for nearly their whole length; claws, stout and black. The female has a reddish brown band across the under side of the body below the slaty. breast band, while the sides of the body are also of this color.

The nest is generally built in a hole in a bank; the bird with claws and bill digs this hole from three to eight feet into the bank; the eggs are generally laid somewhere along this channel, seldom at the extremity. The nest is made of loose grass and feathers and is built during the latter part of April. The eggs are from five to eight in number, of a pure crystal white and measure one and a third by one inch in size.

The birds spend the winter in the southern Middle and Southern States, few wintering in New Jersey; they are found in the Northern States during the warm weather, arriving about the latter part of March and not leaving until ice on the water puts a stop to the food supply.

Their food is exclusively fish.

Kinglet, Golden-crowned.-The two Kinglets, the golden-crowned and the ruby-crowned, are, next to the 


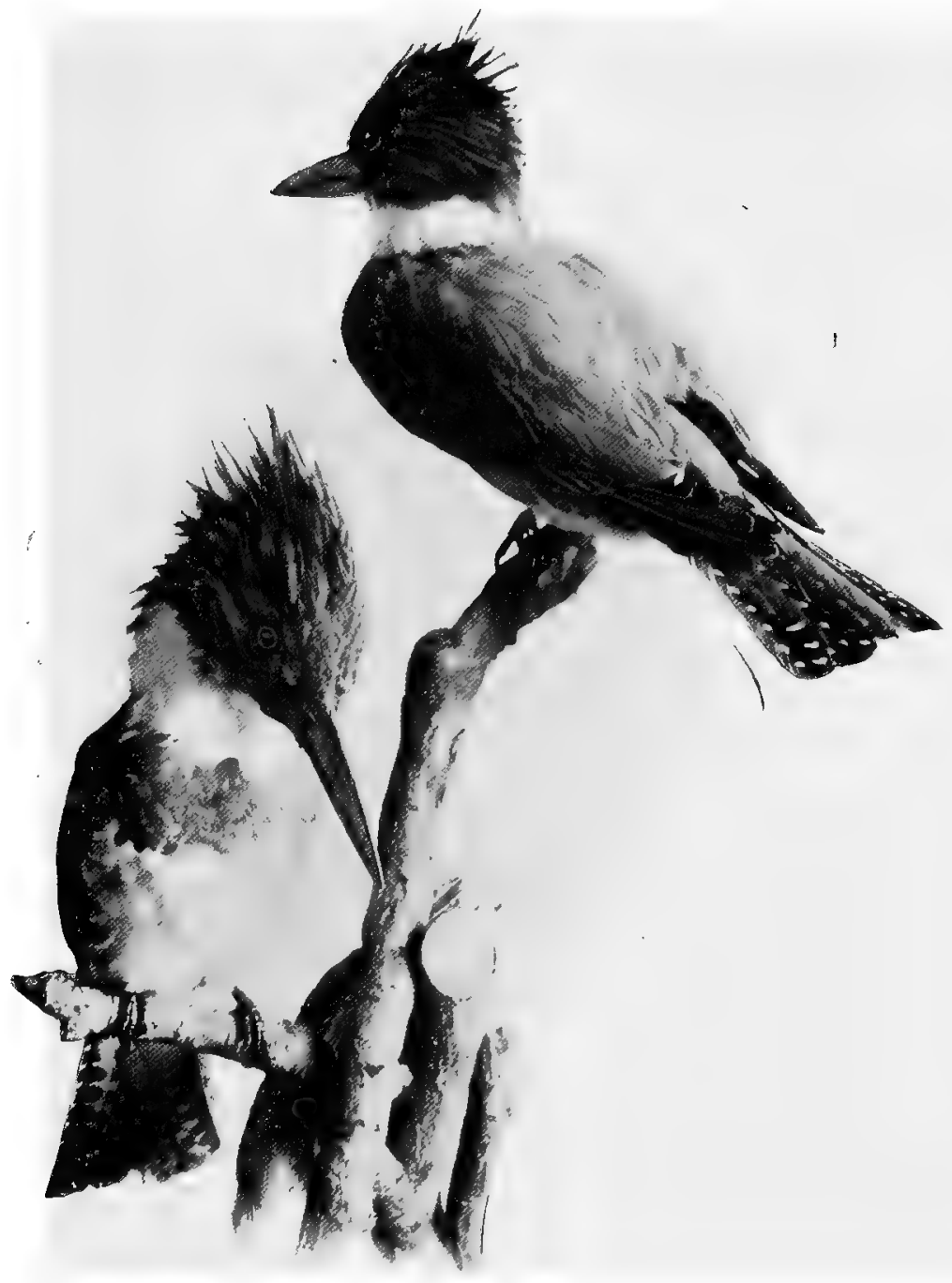

KINGFISHF,RS. 

humming bird, the smallest of the birds which find a home in New Jersey. The Golden-crowned Kinglet is only four inches in length; bill, one-quarter of an inch; upper parts, grayish olive, more ashy on the hind neck; crown black, with a yellow central stripe, in the middle of which is a brilliant orange patch; tail, dark brownish slate, with yellow olive edgings; wings, the same, with two whitish bars across the forepart; under surface of the body, light gray, tinged with olive; a whitish line crosses the forehead and extends back over the eyes; there is a dusky line from the base of the lower mandible, and a dark spot before the eye. The fernale lacks the bright orange centre to the yellow crown stripe.

The nest, considering the size of the bird, is bulky; it is almost invariably found in evergreen trees and is made of moss and lichens, the inside lined with fine bark, small roots and feathers. The eggs are nine or ten in number, of a light gray with brown spots, and one-half by twofifths of an inch in size.

It breeds along the northern border of the United States and northward-also southward along the mountain ranges. In winter it goes as far south as Guatemala. It is a common winter resident in the south in part of $\mathrm{New}$ Jersey, being frequently found in considerable numbers between the first of October and the twentieth of April.

Its call-note is a high $t i-t i$, and its song is described by Mr. Brewster as "a succession of five or six fine, shrill, high-pitched, somewhat faltering notes, ending with a short, rapid, rather explosive warble. The opening notes are given in a rising key, but the song falls rapidly at the end. The whole may be expressed as follows: tzee, tzee, tzee, tzee, ti, ti, ter, ti-ti-ti-ti.

The food of the bird is exclusively insects, which it gathers mainly from the bark of evergreen trees.

Kinglet, Ruby-Crowned.-This bird is a little larger than the preceding but in most respects very similar to it. 
The two are frequently found associated with each other. In plumage the Ruby-crowned Kinglet is exactly like the Golden-crowned, except in the markings of the head. In the present species it is plain olive, like the back, with a central patch of vermillion red, but with no black or yellow; on each side of the eye is a small white spot. The female lacks the red on the head entirely.

The number of its eggs is less, being generally six or eight. It is only transient in New Jersey, occurring in migrations between April 12 and May 1 and again from September 15 to November 1 . Its song is so rich, full, mellow and varied as to be totally unlike that of the Golden-crowned. Mr. Henry Nehrling speaks of the " power, purity and volume of the notes, their faultless modulation and long continuance," and Dr. Coues says that " the Kinglet's exquisite vocalization defies description." It is an industrious destroyer of insects and larvae, but prefers those of the orchard, thus making itself very useful to the fruit-grower.

Kittiwake.-This bird breeds in the arctic regions and occasionally is found along the coast of New Jersey, a fow specimens having been obtained in later years. It is sixteen inches in length, thirty in extent, having a bill one and a third inches long. The head, belly, sides and tail are white; the back and wings, gray; there is a dusky spot over the ear and the tips of the long wing feathers and outer web of the outermost are black, one or two are tipped with white; legs, black; feet, yellow.

Knot, Robin Smipe, or Gray Smipe.-This bird was formerly very plentiful in migrations in New Jersey, but it has been killed off to a great extent, proving an easy prey for pothunters. It breeds in the far north and spends the winter in South America. A few still occur in New Jersey, generally between May 15 and June 1, and again between August 15 and September 15. It is a 
little over ten inches in length; the upper parts are black, feathers all edged with reddish brown; rump, fulvous, feathers barred with black; under parts, rusty fulvous; long wing feathers and tail, dusky, with white shafts, middle of the wing mottled with whitish; winter plumage and young birds, gray above, feathers edged and streaked with black and white; rump, transversely barred with black and white; under surface, white; neck and sides, mottled with gray; various intermediate plumages occur in spring when the birds are changing; the bill is straight and an inch and a half in length. It feeds on small shell-fish along the beaches.

Krieker. See Pectoral Sandpiper.

Lark, Field. See Meadowlark.

Lark, Hormed or Shore Lark.-Length, seven inches; extent, twelve inches; upper surface, ashy brown, tinged with cinnamon, centers of the feathers darked; forehead and line over the eye, pale yellow, center of the head crossed by a black band; both these markings, however, are frequently obscured by brownish tips to the feathers; long wing feathers, dark brown, the outermost edged with white; shoulders, cinnamon; tail feathers, brown, the central pair broadly edged with cinnamon, the outermost edged with white; general color of under surface, white, suffused with brown on the breast, sometimes in definite spots; throat, pale yellow; cheeks and crescent-shaped patch on the breast, black, often obscured by light colored tips to the feathers. The female has little or no black on the crown and the yellow on the front is narrow and of a dirty tinge.

The nest is built on the ground, being a rude contrivance of grasses. The eggs are three or four in number, of a pale blue or greenish white, with dark brown spots, four-fifths by three-fifths of an inch in size.

The birds are winter visitors in New Jersey, going as 
far south as the Carolinas, and are frequently seen in large flocks, especially along the coast. They spend the warm weather in the north.

They feed on the seeds of weeds, such as pigweed, bitterweed, sorrel, etc., and frequently the eggs and larvae of insects; in the spring they frequently destroy recently planted wheat and oats.

Lark, Prairie Horned.-Paler and a little smaller than the preceding, with white forehead and white line over the eye. It is occasionally seen in the winter associated with the preceding, but breeds much farther south, having been found nesting in New York and northern Pennsylvania.

\section{Iark, Shore. See Horned Lark.}

Leadback. See Red-backed Sandpiper.

Linnet, Red-poll. See Red-poll.

Little Blackhead. See Lesser Scaup.

\section{Little Bluebill.-See lesser Scaup.}

Loon.-Length, thirty-two inches; extent, four feet, six inches; bill, a dark yellowish green, two and threefourths inches in length; head and neck, greenish black, a patch of fine black and white stripes on the sides of the latter; back, tail and wings, black, with green reflections, the back and wings being spotted with square white spots arranged in rows; sides of the neck, streaked white and black; breast and belly, white; legs and feet, black and lead; adult in winter and young birds, sooty gray above, feathers of the back all edged with light gray; belly, white; sides of the neck, streaked with gray.

The nest of the Loon is a mere depression in the ground and is invariably found near water. The eggs are two in 
number, of a dark olive brown, with black spots, and three and a half by two and one-fourth inches in size.

The birds breed generally from the northern United States northward, although a few have been known to breed on the lakes of northern New Jersey. They are common on the coast and many winter in the southern part of the state, although the larger proportion goes farther south, some as far as the Gulf of Mexico. They are most plentiful between April 12 and 30, and again between October 3 and November 1 . They are less numerous inland and are never seen there after the ponds and streams are covered with ice.

They feed exclusively on fish.

Loon, Red-Throated.-This bird is seven inches shorter in length than the preceding; in winter the plumage is very similar to the winter dress of the common Loon, but the feathers of the back are more pointed, which makes the borders $V$-shaped instead of rounded; in summer it is greenish black above, with the patch of black and white stripes on the neck as in the preceding species; top and sides of the head, plain drab; throat, bright rusty red; rest of lower surface, white. The bird is rare in New Jersey and occurs only in winter and during migrations.

Mallard. See Mallard Duck.

Marlin, Brown. See Marbled Godwit.

Mrarlin, Hing-tailed. See Hudsonian Godwit.

Marsh Hen. See King Rail.

Martin, Bee. See Kingbird.

Martin, Purple.-Length, eight inches; extent, sixteen inches; bill, one-third of an inch, black; the male is a shining blue black, the wings and tail being somewhat 
duller. The female is dull blackish above, the tips of the feathers slightly glossed with bluish black, with a nearly complete grayish collar reaching around from the throat in a narrow band; throat and breast, ashy; belly, white, all the feathers with dark centers. Young males are like the females, but are darker on the breast. The bill of the Martin is very short and broad at the base, exactly like that of the Swallow, to which the present bird is closely related.

The birds nest in houses built for that purpose or when these are not convenient in hollow trees. The nest is make of twigs and straws, with no attempt at any design. The eggs are either four or five in number, white, and one inch by three-fourths of an inch in size.

The birds breed throughout temperate North America and spend the winter in Mexico. In New Jersey they appear about the first of April and leave about the first of September. They are more numerous in the southern part of the state than in the northern. Some four or five years ago they materially decreased in number, but during the past two years they have been more numerous. Although they persistently annoy hawks and owls, they avoid contact with the English Sparrow, although at times flocks of Martins have been known to rout flocks of Sparrows, especially when the latter had taken possession of the houses occupied by the Martins for a number of years. Their food consists of wasps, bees, beetles and other insects and they are very industrious in providing for their young. Mr. Otto Widmann, of Old Orchard, Missouri, watched a colony of sixteen pairs of Martins from four o'clock in the morning until eight in the evening; during this time the parent birds visited their offspring 3,277 times, or on an average 205 times for each pair. The males made 1,454, the females 1,823 visits.

Mrartin, Sand. See Bank Swallow.

.Marsh Hen. See King Rail and Bittern. 
.Marsh Hen, Salt Woter. See Clapper Rail.

MYeadowiark, or Field Lark.-Length, ten and a half inches; extent, sixteen and a half inches; bill, one and one-fourth inches; upper parts, much mottled with buff, rusty-brown and black, the former tints predominating in autumn and winter; head, mostly black, with a central buff stripe and another over each eye; long wing feathers, light brown, the outer webs slightly spotted, the inner feathers with serrated black stripes down the center; central tail feathers similar, the outer ones more or less white; under surface of the body, bright yellow to the middle of the belly, where it passes into buff; a crescent shaped band of black across the breast; cheeks, a buffy white; sides of the body, light buff, streaked with black; bend of wing, yellow; eyelids, furnished with strong black hairs; legs and feet very large and of a pale flesh color. In winter the whole plumage is much suffused with buff. The sexes are alike in plumage.

The nest of these birds is built on the ground of the preceding year's herbage; it is nicely overarched so as to make it difficult to find. The eggs are from four to six in number, clear white, spotted with brown and purple, and one and one-tenth by four-fifths of an inch in size.

In March large numbers spread themselves all over the United States and Canada, coming from the south; they return in September and October, although considerable numbers winter in the southern part of New Jersey.

Their song is a bright musical twitter, likened by "Mabel Osgood Wright to "Spring o" the y-e-a-r," but more generally considered to resemble "Can't-see-me."

The Meadowlarks are ground feeders, destroying large numbers of insects, even in the midst of winter, being particularly fond of grasshoppers and beetles. In August and September they subsist almost altogether on insects, grasshoppers forming nearly seventy per cent. of their 
diet. Government examination of 238 stomachs, taken at all times of the year, showed that insects formed seventy-three per cent. of the food and vegetable matter twenty-seven per cent. About one-half of the vegetable matter was composed of corn, wheat and oats, the other half being seeds of wild plants, etc. The proportion of grain as established by government examination was: corn, 11.1; wheat, 1.8; oats, 1.4.

\section{Merganser, American, Sheldrake, Goosander,} or Fish Duck.-Length, twenty-sizinches; extent, three feet, three inches; bill, one and a half inches, red and black; entire head, glossy greenish black; neck all around, white; center of back, black, extending down each side of the rump, which with the tail is gray, somewhat mottled with white on the sides; wings, white, long feathers black, some of the others narrowly edged with black, a black bar across the middle of the wing; under surface, pure: white. The female differs in having the head crested and bright rusty in color, while the whole upper surface is gray; a white patch on middle of each wing.

The nest is made of leaves and grasses and lined with down; the eggs are from six to ten in number, of a light yellow, and two and two-fifths by one and three-fourths inches in size.

The birds breed on the northern border of the United States and northward and spend the winter in the south. In New Jersey they are transient, occurring about the middle of October along the coast and on the larger rivers; some winter here.

The food or these birds consists of fish and frogs and their flesh is unpalatable.

Mergamser; Hooded.--Length, eighteen inches; extent, two feet; bill, one and a half inches, blackish red; head with large crest reaching from the forehead to back of the neck, black, with a wedge-shaped patch of white in 


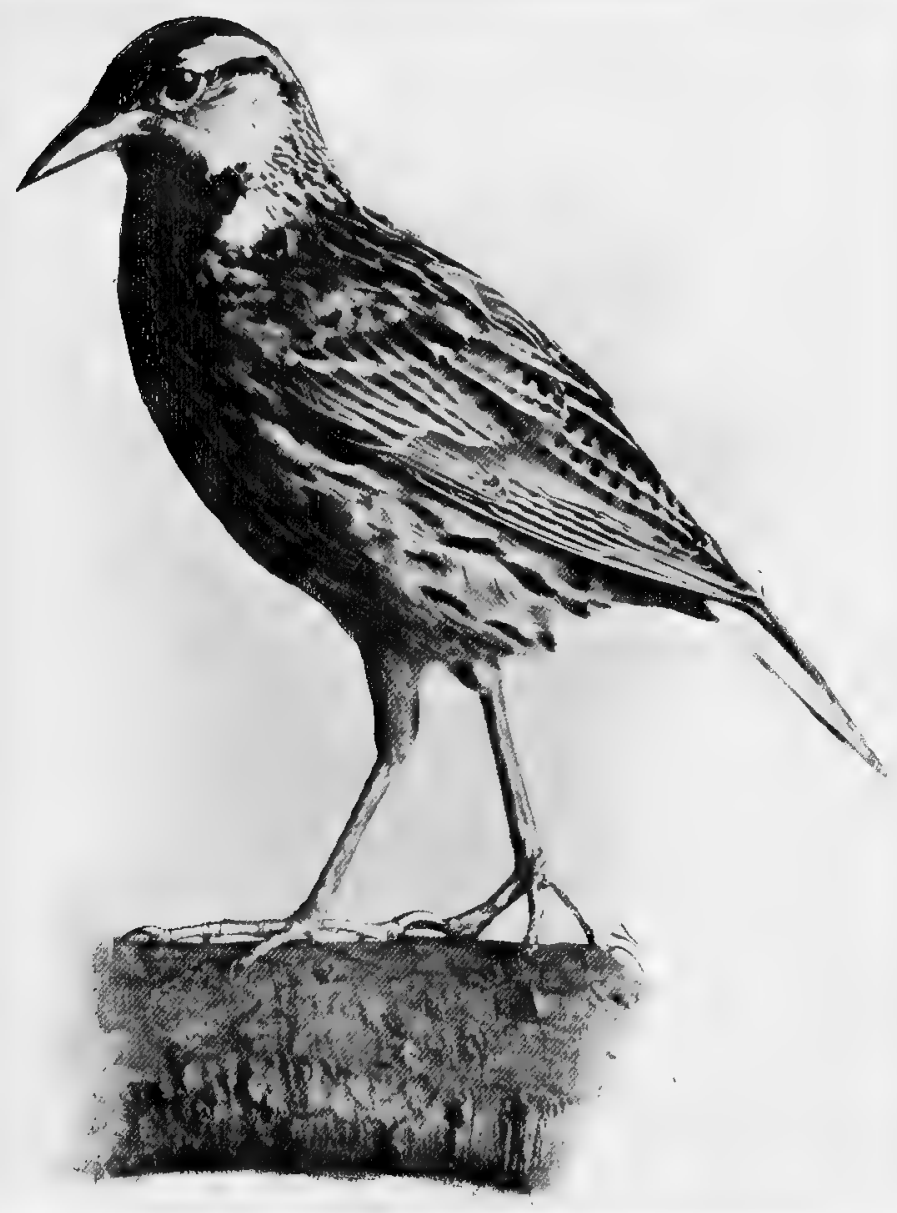

MEADOW I,ARK. 
the middle of the crest; upper parts of the body black; drooping feathers on the inner part of wing with white shafts; bend of wing gray, and a white bar near the middle; tail, dusky; breast, white; two bands of black reach around from the back, but do not quite unite to form collars; rest of under surface white; sides, finely mottled with brown and brown and black lines; thighs, dusky. The female is not nearly so brightly marked; the head is rusty brown; back, dusky, with a white patch on the wing; breast and sides of the body, gray; throat and belly, white.

The birds nest in hollow trees or stumps near water; the nest is built of moss, grass and leaves and lined with down. The eggs are from eight to ten in number, of a yellowish white, two by one and three-fourths inches in size.

Their breeding location is the whole of North America and in winter they are found more towards the south. In New Jersey they are not abundant, occurring during migrations and in winter; they are more numerous in the interior, preferring dead waters.

.Merganser, Red-breasted or Sheldrake.-Length, twenty-two inches; extent, thirty-two inches; bill, one and three-fourths inches in length and red sealing wax in color; upper surface as in the preceding, but the head crested and several white spots on the shoulders; under parts, white, with a rusty band across the breast, most of the feathers within the band centered with black. The female has the head rusty, back gray with white wing bar and shoulder spots.

The birds breed from the northern border of the United states northward and migrate southward in the fall. In New Jersey they are winter residents, but more numerous during migrations. They occur in considerable numbers in November, December and April.

Mother Carey's Chicken. See Wilson's Petrel. 


\section{.VIud Hen. See Clapper Rail.}

Mrud Hen, Red-billed. See Florida Gallinule.

.Murre, Bruenenich's. - Length, sixteen and a half inches; bill, one and one-fourth inches; back, sooty black; breast and belly, white; wings, black, a few feathers being tipped with white. In summer the head and breast are uniform sooty black. These birds nest in colonies on cliffs; the female lays only one egg, three and one-fourth by two inches in size, and in color from a pale blue to a light buff, with brown spots. They bre d north of the Gulf of St. Lawrence and migrate as far south as New Jersey, where they are scarce but regular visitants along the coast. They spend most of the day on the open sea and live on fish exclusively.

Juthatch, Red-breasted.-This and the next species are frequently referred to as "tree mice," on account of their acrobatic performances along the trunks of trees; they run along the trunk of a tree in all kinds of positions, apparently more at their ease when their heads are pointed down. The upside-down position is very characteristic. They seldom if ever run up a tree but start at the top and come down. The Red-breasted Nuthatch is four and a half inches in length and eight inches in extent; bill, half an inch long, very sharp and of a dark lead color; general color above, blue gray; head, glossy black, with a white line from the base of the bill over the eye to the hind neck; long wing feathers, blackish brown, the innermost gray; tail, with central pair of feathers blue gray, others blackish, with a spot of white near the tip of the outer ones; under surface of the body, rusty red, whitish on the throat and gray under the tail. Females and young have the color of the under parts paler and the head tinged with gray.

The birds build their nests of grasses in holes in trees or stumps; the eggs are from four to six in number, white 
with brown spots, and three-fifths by one-half inch in size.

They breed north of the United States and in winter migrate to south of the Middle States; in New Jersey they are inainly transient, occurring about the middle of May and again from September 10 to October 15, being far more plentiful in some years than in others. Occasionally a few remain through the winter.

'Their food consists principally of seeds from pine cones.

Nouthatch, W'hite-breasted.-Length, five and a half inches; extent, eleven inches; bill, three-fourths of an inch, dark gray; the plumage is very similar to that of the preceding. There is no distinct line on the side of the crown, as the whole side of the head to above the eye is white. The inner wing feathers are largely black on the inner webs, and the white marks on the tail are more prominent; the whole under surface is silky white, except the flanks and feathers under the tail, which are tinged with rusty red and chestnut. The female and young have the head tinged with gray.

The birds build nests of feathers, leaves and moss in holes in trees and stumps; the eggs are from five to eight in number, white with brown spots, and three-fourths by three-fifths of an inch in size.

They breed and are distributed at all seasons throughout the eastern United States, but are most plentiful in New Jersey in winter and during migrations.

Their food consists of the grubs and eggs of insects, which they gather out of the bark of trees.

old Squaw. See Old Squaw Duck.

old Wife. See Old Squaw Duck.

Oriole, Baltimore, Golden Oriole, Fire Bird, Golden Robin, or Hangnest.-Length, seven inches; extent, eleven inches. The bill is almost straight, strong, 
and tapering to a point, bluish lead-colored, two-thirds of an inch in length; head, throat and upper part of the back, black; lower part of the back, rump and whole under parts, bright orange, deeper on the breast; the black on the shoulders is divided by a band of orange; wings, black, edged with white; tail, black and orange, slightly forked; legs and feet, light blue or lead color. The female is yellow olive above, the head and back more or less spotted with blackish; tail and rump, uniform yellow olive, inclining to orange; wings, dull brown, with whitish edgings; under surface of body, pale orange, with more or less dull black feathers on the throat and sides of the head. Young like the female, but darker above, and with no black marking on back, head or throat.

The nest is variable, depending a great deal on whether the bird is breeding near civilization or in the wilderness. It prefers the extreme end of an upper branch of a tree in an orchard, near enough to the house to keep hawks away and with the branch light enough to sway in the wind. The nest hangs from the branch and, when near human habitation, the entrance is near the top, wide open and the nest is long and narrow. When found in the wilderness the opening is said to be often far smaller and the nest is more the shape of a bottle. It is finely woven together, the materials being plant fibre, string, hair, flax, tow.or anything of the kind the bird can get hold of. The eggs are from four to six in number, fourfifths by three-fifths of an inch in size, white with black and brown scrawls.

The birds breed in the eastern part of the United States, north of Virginia, where they put in an appearance about the first of May. They remain here until about the middle of August and are more numerous in the northern part of the state than in the southern.

Their song is shrill, but somewhat martial, and they have two song seasons, one during mating and another in August until they leave. 
Government examinations of 113 stomachs showed that the contents were composed of 83.4 per cent. of animal matter and 16.6 of vegetable matter. In May the contents were 92 per cent. insects and in April and July 70 per cent. Caterpillars composed 34 per cent. of the total contents and there were large numbers of beetles. In the vegetable line the bird prefers fruit, cherries, berries and grapes, taking very little grain.

Oriole, orchard.-Length, six and a half inches; extent, eleven inches; bill, two thirds of an inch. In the female the color above is a light olive; wings, dusky brown, tipped with white; whole lower parts, yellow; bill and legs, light lead color, the former slightly curved, very sharp-pointed and black towards the extremity. The young male of the first season corresponds nearly with the adult female in plumage. In the succeeding spring he makes his appearance with a large patch of black on the throat. The plumage of the third year in addition to the black throat has more or less black on the tail, black spots on the head, and patches of chestuut brown on the breast and rump. In the final plumage, supposed to be acquired in the fourth year, the entire head, fore breast and back are black, rump and rest of under surface, chestnut brown; tail, black; wings, dull black, edged with whitish and with a chestnut patch on the shoulders. The female remains always in the yellow and olive dress.

The nest is generally found hanging from the extremity of a limb of a fruit or shade tree, from ten to fiteeen feet from the ground, very evenly woven and made mainly of dry yellow grass, and lined with wool or some soft substance. The eggs are from four to six in number, fourfifths by three-fifths of an inch in size, of a blue white, scrawled and spotted with dark brown.

The birds winter in Mexico and the south, from which they spread themselves over the eastern United States, 
remaining here from the first of May to the first of September.

The song is considered by many finer than that of the forner, being more dulcet in tone and less shrill; its song season is however very brief.

The food consists chiefly of insects, which it frequently gathers from fruit blossoms without doing the least injury to the blossoms; it is fond of cabbage worms, rosewings and beetles, and also feeds on berries.

Osprey, or Fish Hawk.-Length, twenty-two inches; extent, five feet, two inches; the fernale is two inches larger; bill, bluish black. The upperparts are a dark slate color, with an admixture of white in the head and neck and many of the feathers of the back edged with white; the tail is tipped with white and crossed by bands of brown; the under parts are white. The females have more or less brownish spots across the breast and these markings are also at times found in the males. The legs and feet are light blue.

The nest is an exceedingly bulky contrivance, generally found in a tree, from fifteen to fifty feet from the ground, but also occasionally on the ground; it is built of sticks, reeds, cornstalks and wet turf, lined with salt meadow hay and seaweed. The eggs are from two to four in number, two and three-fourths by one and three-fourths inches in size; they are of very different colors, generally a creamy white with brown spots, but at times also a dull white or a light brown.

The birds breed throughout temperate and tropical America and in winter frequent the coast of the southern Atlantic states. They appear in New Jersey along the coast shortly after the middle of March and leave again about the middle of October; they are more numerous in the southern part of the state than in the northern.

Their food consists exclusively of fish, which they generally take alive from the water, frequently diving after 


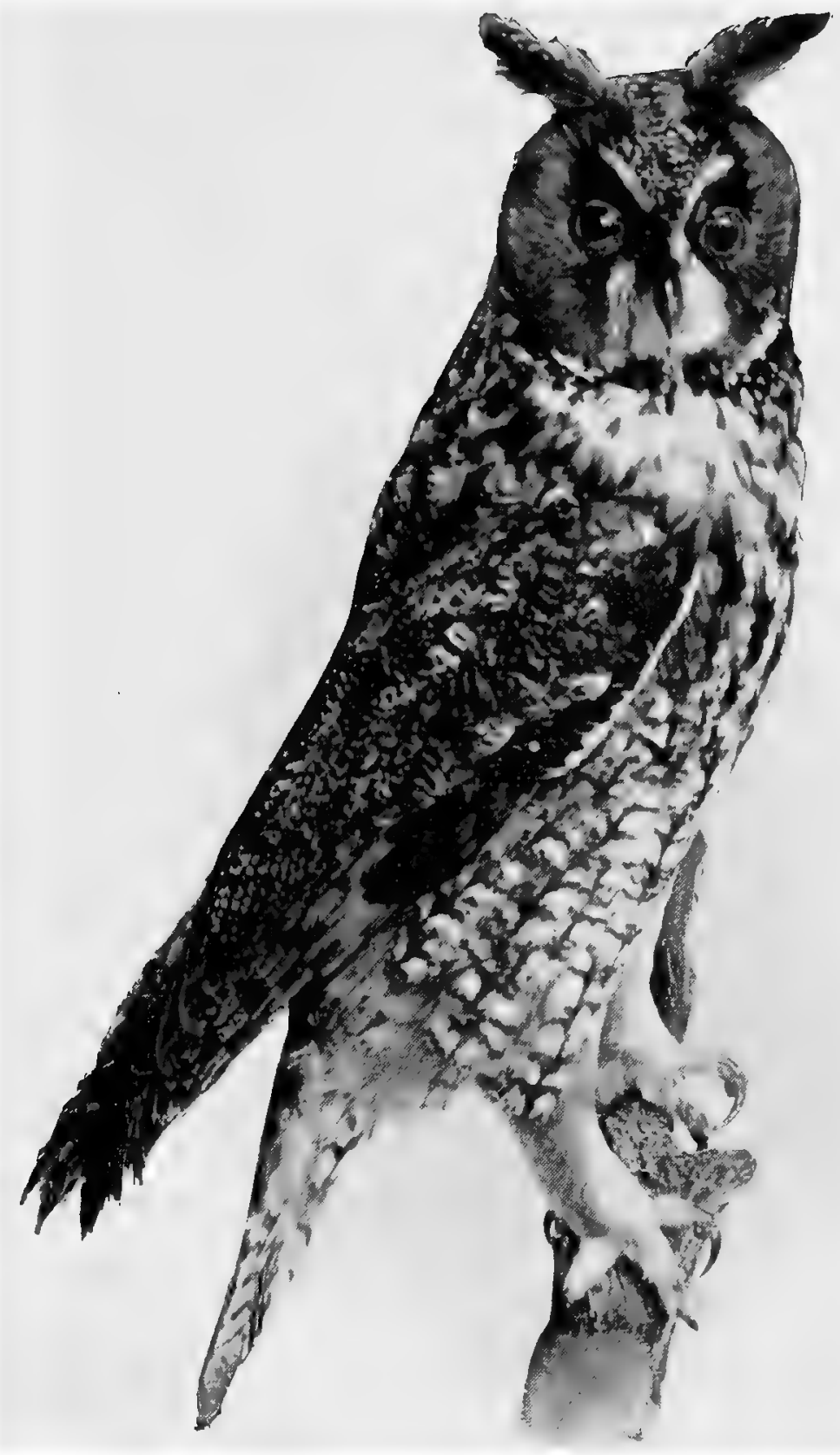

LONG-EARED OWL。 
their prey to considerable depths. They are great favorites with the inhabitants of the coast and, being quite inoffensive as well as attractive, well merit the protection which is accorded them in several of the seaboard counties of the state.

Ovenbird, or Golden-crowned Thrush.-Length, six and one-fifth inches; extent, nine inches; bill, onethird of an inch, brown. The upper parts, the wings and the tail are olive-green; the head marked by two longitudinal black stripes, between which the feathers are dull brownish orange; the under parts are white; the breast, the sides and the sides of the throat streaked with black; legs and feet, flesh-colored.

The nest is a bulky contrivance, hut-like, with the entrance from one side and very difficult to find. It is built on the ground of stalks, weeds, grasses and leaves. The eggs are either four or five in number, white with brown spots, three-fourths by three-fifths of an inch in size; there are two broods a year.

The birds breed in New Jersey and from here northward to Hudson's Bay, aud spend the winter in Florida and further south. They are very plentiful in New Jersey, especially in the mountains and in the pine barrens of the southern part of the state.

They have a song very intricate and melodious, but seldom heard and a regular familiar call, generally cornpared to the word teacher, several times repeated and each time on an ascending scale.

The food of the bird consists of small bugs and the larvae of insects which it gathers from the ground.

Owd, ffcadian. See Saw-whet Owl.

Owt, Barn, or Monkey-faced Owl.-Length, fourteen inches; extent, three and a half feet. The bill is of a whitish-horn color, one and one-fourth inches in length; space surrounding each eye remarkably concave, the ra- 
diating feathers meeting in a high projecting ridge, arching from the bill upwards; between these lies a thick tuft of bright tawny feathers that are scarcely seen unless the ridges be separated; face, white, surrounded by a border of narrow, thickset, velvety feathers, of a reddish cream color at the tip, pure silvery white below and finely shafted with black; the whole upper parts finely mottled with black and gray, each feather of the back and large wing feathers ending in an oblong spot of white, bounded by black, and all the feathers broadly bordered and suffused with tawny buff; sides of the neck, pale yellow ochre, thinly sprinkled with touches of dusky; long wing feathers barred with dusky brown; tail, two inches shorter than the tips of the wings, pale yellowish, crossed with five bars of brown and thickly dotted with the same; whole lower parts, white, thinly interspersed with small round spots of blackish; legs, long, thinly covered with short white down, nearly to the feet, which are of a dirty white; toes, thinly clad with white hairs. The ridge or shoulder of the wings is tinged with bright orange brown. The aged bird is more white; in some the spots of black on the breast are missing and the color below is a pale yellow, in others a pure white.

The nests are found in barns, towers, belfries, steeples and holes in trees and banks. Mating begirs late in Febuary or early in March. The eggs are from five to nine in number, of a dirty white, and one and three-fourths by one and one-third inches in size.

The birds are distributed throughout the southern United States and the southern parts of New Jersey, Pennsylvania and New York.

Their cry is a cr-r-ree, cr-r-ree, cr-r-ree, or a quaek, quaek, quaek.

Government reports of the examination of 7 stomachs showed that 1 contained poultry, 1 other birds, 4 mice, 1 other mammal, 3 insects; examination of 29 stomachs 


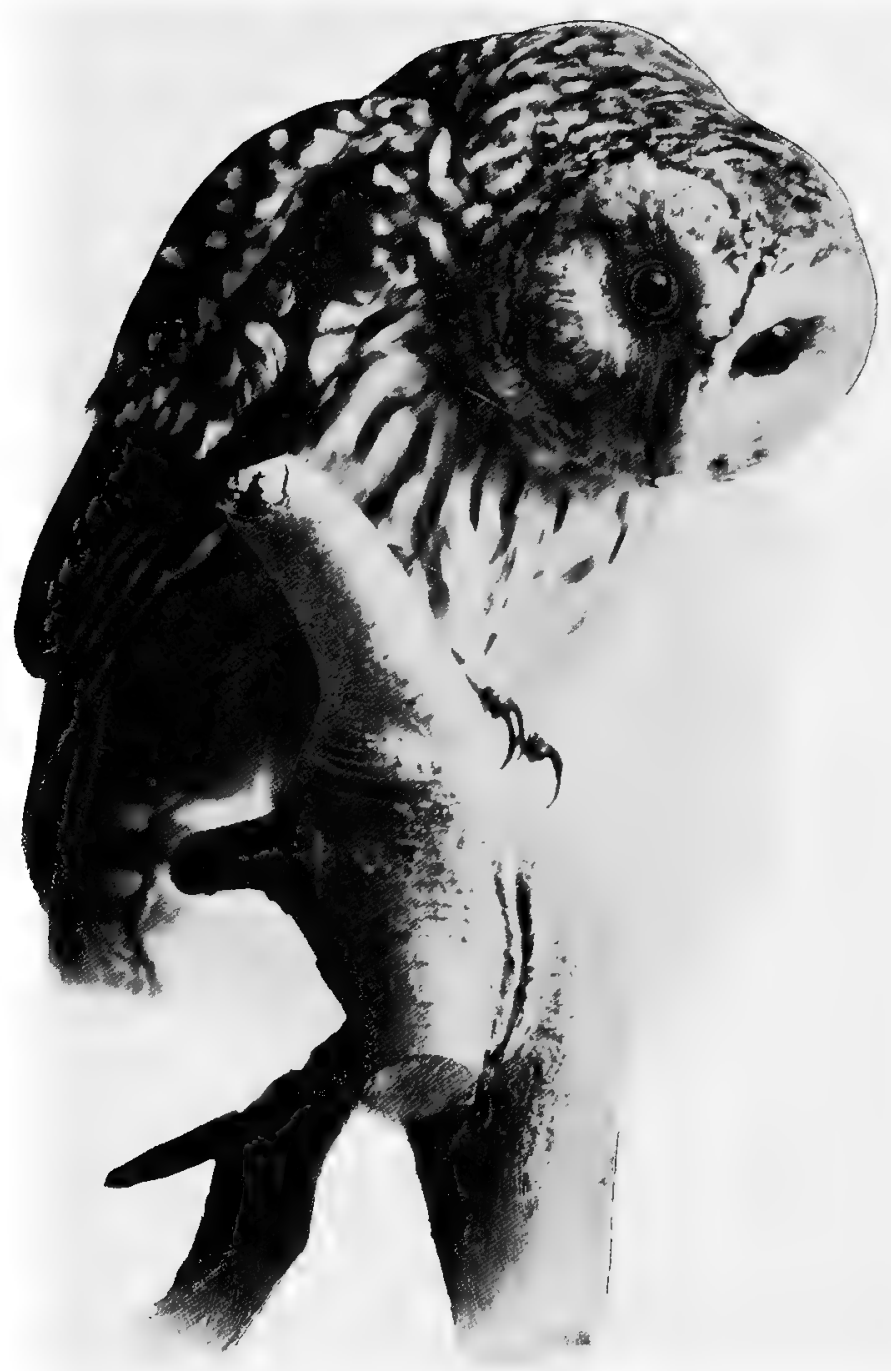

BARRED OWI. 

showed that 1 contained poultry, 3 other birds, 17 mice, 17 other mammals, 4 insects and 7 were empty.

Owi, Barred, or Hoot Owl.-Length, sixteen and a half inches; extent, thirty-eight inches; bill, one and a half inches, yellow with a greenish tinge; above, dark brown, some of the feathers with rusty markings and all barred transversely with white, bars broken into spots on the shoulders; wings and tail, dark brown, transversely barred with white; face and breast, dull white, barred with dark brown; belly, white, streaked longitudinally with brown; legs, dull white, tinged with brown.

The birds nest in hollow trees and some times in abandoned Crow's or Hawk's nests. The eggs are two to four in number and two inches by one and three-fifths in size.

They breed between southern Canada and Georgia, generally in the mountain forests and are rare visitants to New Jersey.

Government examination of 109 stomachs showed that 5 contained poultry or game, 13 other birds, 46 mice, 18 other mammals, 4 frogs, 1 lizard, 2 fish, 14 insects, 2 spiders, 9 crawfish and 20 were empty.

owt, Cat. See Long-eared Owl.

Owl, Great. Hormed, or Hoot Owd.-Length, twentytwo inches; extent, four feet, three inches; the female is two inches larger. The bill is one and two-fifths inches long, black and powerful, covered at the base with a cere; eyes, golden yellow; the horns are three inches in length and very broad, consisting of twelve or fourteen feathers, their webs black, broadly edged with tawny; face, rusty, bounded on each side by a band of black; space between the eyes and bill, whitish; whole lower parts elegantly marked with numerous transverse bars of dusky, on a bright tawny ground, thinly interspersed with white, white more conspicuous on the center of the breast; legs and feet, large and covered with feathers, or 
hairy down, of a pale brown color; claws, very large, blue black; tail, rounded, extending about an inch beyond the tips of the wings, crossed with six or seven narrow bars of brown and variegated or marbled with brown and tawny; whole upper parts finely pericilled with dusky, on a tawny and whitish ground; chin, pure white, under it a band of brown, succeeded by another of white. The white on the throat of the female is not as pure and she has less of the bright brown or tawny tint below.

The bird generally lays its eggs in the nest of some other bird or a squirrel, occasionally in a hollow tree. The nest is constructed of a large number of sticks and leaves, with a few feathers. The eggs are from two to four in number, of a pure white, almost spherical, two and twofifths by one and four-fifths inches in size.

The birds breed and are distributed over the whole of eastern North America.

Their cry is one of the must startling and blood-curdling screams imaginable, sounding like waugh $O$, waugh $O$, uttered in a most piercing tone. At other times it satisfies itself with a long continued whoo, hoo-hoo-hoo, whooo, whooo, but this is almost as bad as the other cry. Fortunately the bird avoids settled districts.

The bird is very fond of chickens, game birds and rabbits. Reports of government examination of 30 stomachs showed that 16 contained poultry or game birds, 2 other birds, 1 mice, 12 other mammals, 2 insects, 1 was empty. Examinations of 127 stomachs showed that 31 contained poultry or game birds, 8 other birds, 13 mice, 65 other mammals, 10 insects, 1 scorpion, 1 fish and 17 were empty.

Owt, Hoot. See preceding and Barred Owl.

Ouvl, Long-eared, or Cat Owl.-Length, fifteen inches; extent, three feet, two inches; the ear tufts are very prominent, over an inch in length, gradually lengthening 


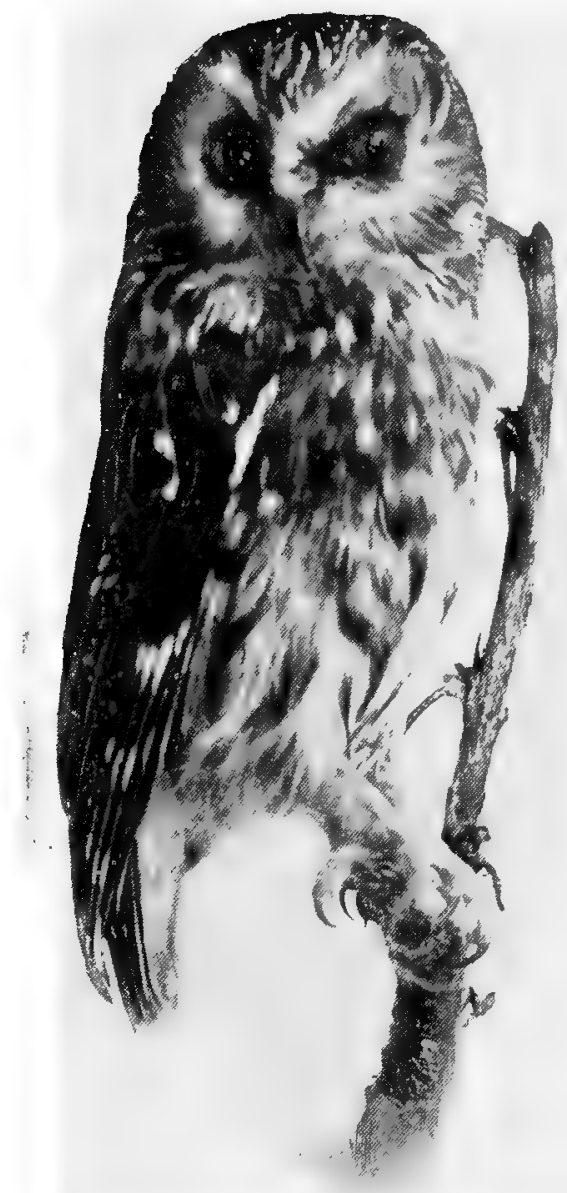

SAW WHE'T OWL. 

from the front backwards, black, with white and buff margin; face, bordered with black; eyes, yellow; bill, one inch in length, blackish horn color; forehead and crown, deep brown, speckled with minute spots of white and rusty; back and upper parts generally very similar to the preceding; breast and under parts coarsely streaked with black and buff, the belly transversely barred with dark brown and white, each feather centrally streaked with dusky; tail, rounded, same length as the wings, dark brown, marbled with dull white and rusty, with six or eight bar's of dark slate; upper wing, dark brown, sprinkled and spotted with white, pale brown and dusky; legs, plain pale rusty, feathered to the claws; claws, bluish black, large and sharp.

The birds very rarely build their own nests; generally they lay their eggs in the abandoned nest of a Crow, Hawk, Heron or Squirrel. The eggs are from three to six in number, of a dirty white, and one and three-fifths by one and one-third inches in size.

The birds breed and are distributed throughout temperate North America, and are fairly common, more numerous in winter, when they are at times seen in colonies of considerable numbers.

Their cry is variable, from a hoot slightly resembling the barking of a young dog to the mewing of a cat.

This Owl is strictly nocturnal and never feeds in the day time. It is a beneficial bird, as will be seen by the following results of the examination of 107 stomachs: 1 contained a game bird, 15 other birds, 84 mice, 5 other mammals, 1 insects and 15 were empty.

\section{Dwt, Monkey-faced. See Barn Owl.}

Dav, Saw-whet, or Acradian Owl-LLength, eight inches; extent, sixteen inches. Its small size and absence of ear tufts makes it readily distinguishable from others of the Owl family. The bill is black and two-fifths 
of an inch in length; the upper parts are a dark brown, the head being finely streaked and the back spotted with white; the under parts are white with reddish brown streaks and mottlings; tail, brown, having three or four narrow white bars; eyes, yellow; legs and feet, feathered, white. This Owl is very easily captured, it is also very easily tamed. The head is frequently used for millinery purposes and a combination of all these facts has made the bird scarce.

The eggs of this bird are frequently found in a hole in a tree in an abandoned Squirrel's or Woodpecker's nest; they are from three to five in number, of a pure white, one and one-fifth by one inch in size.

The bird breeds in the northern United States and British America and in the winter spends its time further south as far as the Middle States. In New Jersey it is a rare winter visitor.

The cry of the bird resembles the filing of a saw, from which fact it has derived its name.

Government reports of the examination of 22 stomachs showed that 17 contained mice, 1 a bird, 1 an insect and 3 were empty.

owl, screech.-Length, eight and a half inches; extent, twenty-one inches. There are two phases of this bird found in New Jersey, the red and gray, but the former predominates. The bird is easily known by its small size and ear tufts; the coloring is not dependent either upon sex, age or season, both colors frequently occurring in the same brood. The general color of the plumage of the red phase is a bright tawny red above; the shafts of the feathers are black; exterior edges of the feathers of the shoulders, white; whole wing quills, spotted with dusky on their exterior webs; tail, rounded, transversely barred with dusky and pale brown; chin, breast and sides, white, streaked with black and more or less mottled with rusty; middle of belly, white; legs, 


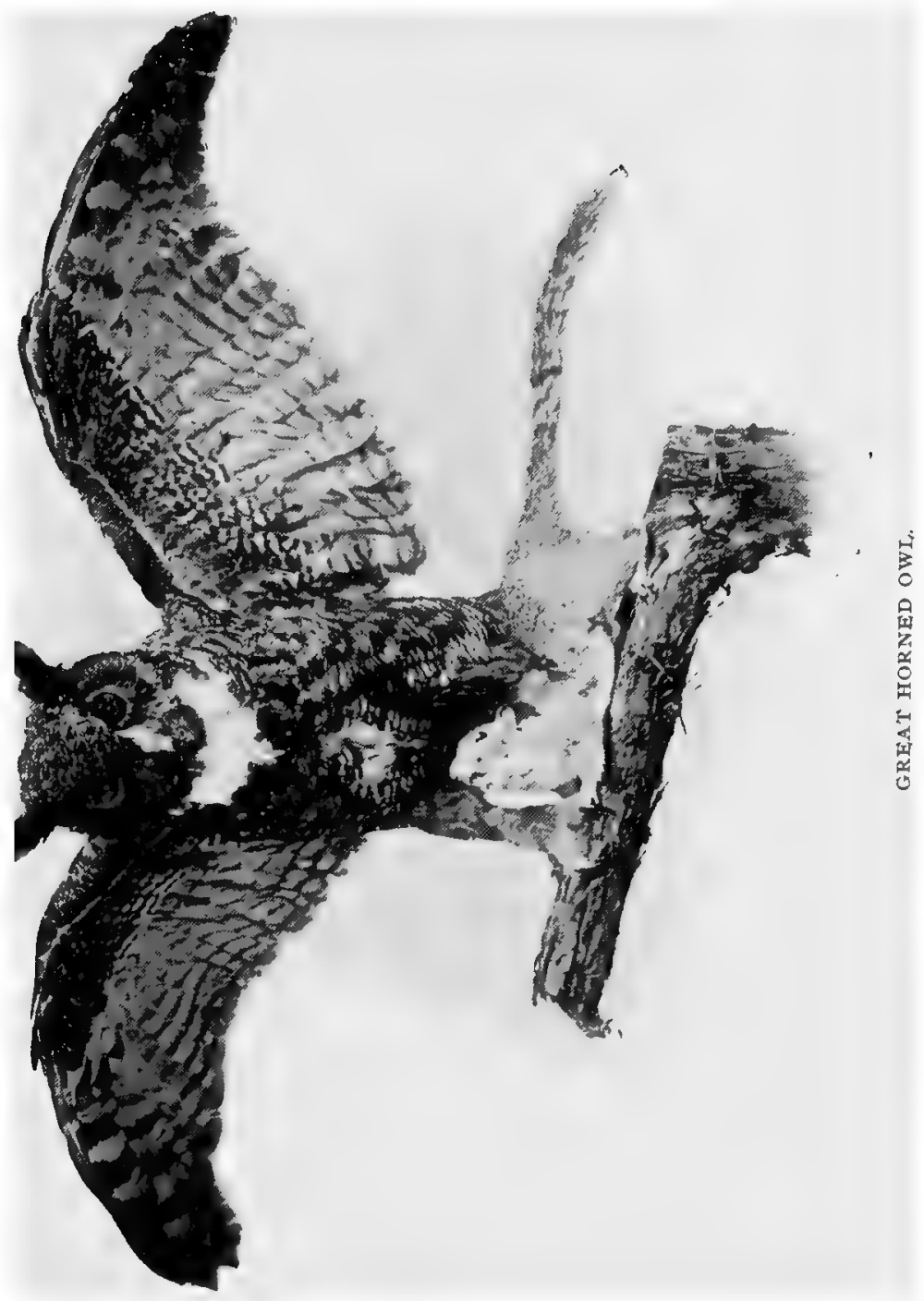



feathered to the claws; extremities of the toes and claws, white, pale bluish, ending in black; bill, two-thirds of an inch in length, a pale bluish horn color; eyes, vivid yellow; head, horned or eared, each horn tuft consisting of nine or ten feathers, of a tawny red, shafted with black. In the gray phase of the bird the upper parts are generally brownish gray, streaked with black and mottled with buff; the under parts are white, streaked and irregularly barred with black, and banded with brown. In the young the entire plumage is barred with grayish, brown and white.

The nest is generally built in the hollow of a tree-an old apple tree preferred-and not over ten feet from the ground, occasionally in a dove cote, but never in branches of trees, nor does the bird make use of the nests of other birds; the nest is a rude affair, made of sticks and leaves, incompletely lined with a few feathers. Mating begins about the middle of April. The eggs are from four to six in number, almost spherical, rough surfaced, of a dirty white, and one and a half by one and a quarter inches in size.

The birds breed and are distributed over the whole of the eastern part of the United States from Canada to the Gulf of Mexico.

Their cry is shay, shay, shay, at night a tremulous wailing whistle.

The food of this bird is largely insectivorous, but they will also take quail and young chickens and are very fond of the English Sparrow. Government reports of the examination of 94 stomachs showed that 1 contained poultry, 20 other birds, 41 mice, 1 other mammal, 1 frog, 35 insects, 3 crawfish, 1 spider, 1 indeterminate matter and 7 were empty. Reports of the examination of 255 stom. achs showed that 1 contained poultry, 38 other birds, 91 mice, 11 other mammals, 4 frogs, 100 insects, 2 lizards, 1 fish, 2 scorpions, 2 earthworms and 43 were empty. 
Owt, Short-eared.-Length, fifteen inches; extent, three feet, four inches; whole upper surface, longitudinally streaked with dark brown and buff, with round buff spots on the wings and middle of the back; bill, one and a quarter inches, black; eyes, rich golden yellow, placed in a bed of deep black, which radiates outward all around, except towards the bill where the plumage is white; ears, bordered with a semi-circular line of black and tawny yellow dots; tail, rounded, longer than usual with Owls, crossed with five bands of dark brown and as many of yellow ochre, some of the latter having central spots of dark brown, the whole tipped with white; quills, banded with dark brown and yellow ochre; breast and belly buff, longitudinally streaked with dark brown; legs and thighs, plain buff, tips of the three first quill feathers, black; legs, clothed to the claws, which are black, curved to about the quarter of a circle and exceedingly sharp. The female is somewhat larger and much darker; the spots on the breast are larger and more numerous.

The nest is a depression in the ground generally under a bush; it is made of coarse grass and sticks and lined with finer material and feathers from the parent bird. Mating begins in April or May. The eggs are from three to five in number, of a soiled white, and one and threefifths "by one and one-fourth inches in size.

The birds breed and are distributed over the whole United States, in fact, nearly all over the world. In the United States they are more numerous in winter owing to large accessions from northern regions.

Their cry is a harsh quaver.

Government examinations of 45 stomachs showed that 4 contained small birds, 34 mice, 3 other mammals, 7 insects, 6 were empty. Examinations of 101 stomachs showed that 11 contained small birds, 77 mice, 8 other mammals, 7 insects, and 14 were empty.

Owl, smovy.-Length, twenty-two and a half inches; 


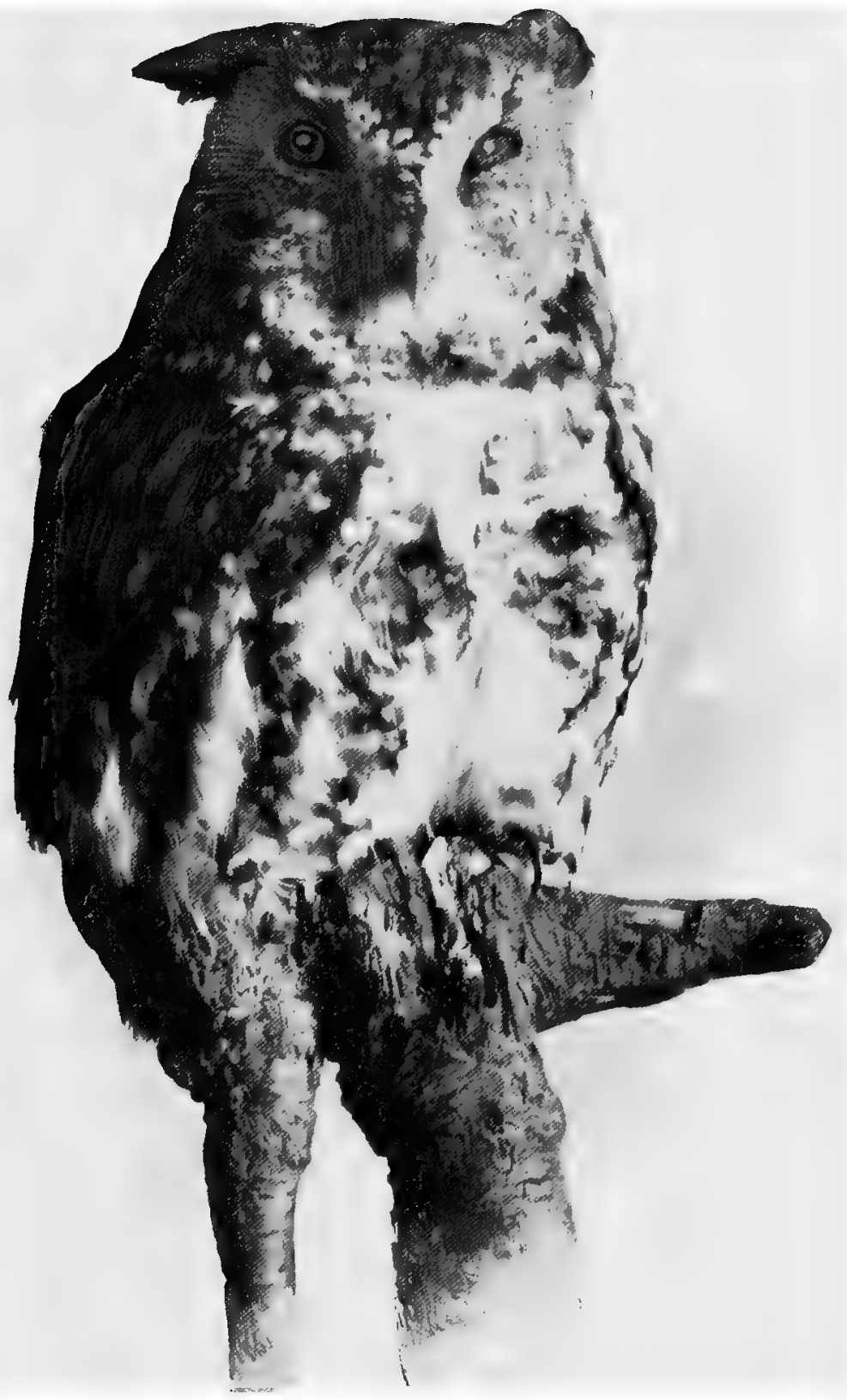

SCREECH OWI. 

extent, four feet, six inches. There are no ear tufts and the general coloring of the bird is pure white, with more or less spots and bars of grayish brown or dark slate. The bill is one and a half inches in length. The eyes are a brilliant golden yellow; legs, heavily feathered; feet, black, and also heavily feathered. The female is twentyfive inches in length and more heavily barred and spotted. The young birds are darker.

The nest is built on the ground of sticks and leaves and lined with feathers. The eggs are from three to ten in number, white, and two and one-fourth by one and threefourths inches in size. The eggs are laid at long intervals apart, the first-laid egg being hatched before the last is deposited.

The birds breed in the northern part of North America and in the winter go south, sometimes as far as the middle of the United States. They are irregular winter visitors to New Jersey, in some years far more frequent than in others, and invariably more numerous along the coast.

Their cry is a growl, a hoot and a bark.

They feed principally in the evening and in the early morning, and destroy large numbers of hares, partridge and ducks.

Government examination of 38 stomachs showed that 2 contained game birds, 9 other birds, 18 mice, 2 other mammals and 12 were empty.

Ox-eye. See Semi-palmated Sandpiper.

Ox-eye, oreadow. See Least Sandpiper.

Partridge. See Ruffed Grouse.

Peabody-bird. See White-throated Sparrow.

Peep. See Least Sandpiper, and Semi-palmated Sand. piper.

Peetureet. See Spotted Sandpiper. 
Phoebe Bira or Pewee.-Length, seven inches; extent, eleven inches. The upper parts are of a grayish brown, considerably darker on the crown; wings and tail, dark brown; the outer vane of the outer tail feather, yellow ish white, except at the tip; the under parts are dull white, with a yellowish tinge and a brownish gray patch on each side of the breast, almost forming a band; the bill is black and two-fifths of an inch in length; feet, black; feathers of the head, slightly crested.

The nest is built of moss, mud and grasses, and is almost invariably found on a beam or rafter of a bridge or piazza, or any convenient place near human habitation, though occasionally on rocky cliffs or an upturned stump. The eggs are from four to five in number, white, occasionally with brown spots, and three-fourths by three-fifths of an inch in size. There are two broods a year.

The birds spread themselves over the eastern part of the United States from the south, arriving in New Jersey in the latter part of March and returning towards the end of October; one or two are occasionally found in winter.

Their cry is a plaintive pewit-phoebe.

Their food consists of insects of all kinds, principally weevils.

\section{Pewee, Wood, or Wood Pewee Flycatcher.-} Length, six inches; extent, ten inches; bill, two-fifths of an inch; plumage practically identical with the preceding, from which it differs mainly in size. The lower mandible, however, is yellow and the outer tail feather lacks the white on its outer web.

The nest is flat and built on the upper branch of a tree; it is made of fine grasses and small roots, covered with lichens. The eggs are either three or four in number, white, with a wreath of brown or lilac near the larger end, and seven-tenths by one-half inch in size.

The birds come from the south to the eastern United 
States, arriving here during the early part of May and returning shortly after the middle of September.

Their song is pee-a-wee, pee-wee-a-peer, all day long.

Their food consists of insects, the common housefly being apparently preferred.

\section{Petrel, Wilson's, Stormy Petrel, or .Nother} Carey's Chicken.-Length, seven inches; extent, fourteen inches; bill, half an inch in length, black; back, sooty black; belly, grayish black; tail, black, nearly even at the tip, slightly forked feathers at the base of the tail both above and below, white; wings, sooty black, with gray edging to the smaller feathers; legs and naked part of the thighs, black; feet, black, with yellow webs; legs from toes to the beginning of the feathered part three and one-quarter inches.

These birds are occasionally seen along the coast of New Jersey, generally after a storm, but they spend most of their time on the high seas. They breed on isolated rocky islands, the female laying one white egg.

Pine Siskin. See Pine Finch.

Pintail. See Pintail Duck.

Pitit. See Titlark.

Plover, Black-bellied, or Beetle-head.-Length, eleven inches; extent, twenty-two inches; bill, one and one-tenth inches, black; above, coarsely mottled with black, white and gray; head, gray, forehead and hind neck nearly white; long wing feathers, black, with white on the inner webs, tail barred transversely with black and white; below, jet black, except the lower belly, thighs and feathers under the tail, which are white; sides of head and neck, uniform black. In fall the plumage lacks the black color beneath, being white, mottled on breast, neck and sides of head with gray. During spring all sorts 
of intermediate specimens are found. Young are like the old birds in winter dress; legs and feet, grayish white.

The nests are depressions in the ground, lined with grass and moss; the eggs, generally four in number, vary in both color and size; they are from a brown to a greenish drab in color, with brown spots all over, and vary from two to two and one-third inches in length and from one and two-fifths to one and a half inches in breadth.

The birds breed in Alaska and Siberia and other northern countries and in winter migrate to South America. In New Jersey they are transient, occurring between the last of April and May 22, and again from July 20 to September 15 .

When they are found along the sea coast and in salt water marshes-and they are more frequent there than in the interior-they feed on insects, shellfish and small fish, their flesh then having a sedgy flavor; when found on the uplands and feeding on grasshoppers, field insects and berries, their flesh is more palatable.

Plover, Field. See Bartramian Sandpiper.

Plover, Grass. See Bartramian Sandpiper.

Plover, Golden, or Green-back.-Length, ten inches; extent, twenty inches. Above, black, spotted and mottled with golden yellow; top of the head, nearly uniform black, forehead and sides of neck, white, and a white patch on each side of the breast; long wing feathers, dusky, with shafts pure white; tail transversely barred with dark brown and dull white, under surface uniform black. Young birds and adults in winter lack the black under parts, which are dull white, mottled with gray on the breast.

Their nest is circular, among moss or grass, lined with grass and dead leaves. The eggs are generally four in number, of a pale yellow, with dark reddish brown spots, 
one and nine-tenths by one and three-tenths inches in size.

The breeding location and distribution is the same as the foregoing. In New Jersey they are very erratic in appearance, some years being very scarce and in other years occurring in large flocks in the fall. They are more frequent on the sea coast and at times are seen far out at sea.

The flesh of these birds is considered excellent for the table; they feed on insects, principally in marshes and on sandy hills and flats and old fields.

\section{Plover, Killdeer. See Killdeer.}

Plover, Piping.--Length, seven inches; extent, fourteen inches; bill, half an inch in length, orange, tipped with black; feet, greenish yellow, nails black; above, pale gray; forehead, ring around hind neck, and entire lower parts white, a black band across the crown and a black patch on each side of the breast; long outer wing feathers, black on outer web and at tip; two outer tail feathers nearly pure white, others dusky, passing into black with white tips. The female is rather duller in its markings; adults in winter and also the young birds have the black markings of the body replaced by gray.

The nest is a depression in the sand and is very difficult to find on account of the close resemblance between the color of the eggs and the surroundings. The eggs are generally four in number, of a light yellowish drab, with black and brown spots, and one and one-fourth by one inch in size.

The birds breed from the southern coast of Labrador to Virginia and spend the winter in the south Atlantic states as far south as the West Indies; a few breed and a few winter in New Jersey; formerly they bred abundantly.

The food consists of insects and small crustacea gathered from the tide-washed sands; the flesh is palatable when the birds are fat, but frequently has a sedgy flavor. 
Plover, Maddy. See Sanderling.

Plover, Semi-palmated, or Ring-necked Plover. -Length, seven inches; extent, fourteen inches; bill, half an inch, orange in color; above, grayish brown; forehead, ring around hind neck and entire under parts white; a band across the crown, and one from the nostril to the breast, as well as a conspicuous breast band, black; wings and tail as in the preceding, but with less white. The female is somewhat duller, and young as well as winter adults are marked with gray instead of black. While the darker back and complete band across the breast serve to distinguish this bird from the Piping Plover, it also differs in the webbing of the feet; in this species the middle toe is connected with both the others by a short web, while in the other only the outer and middle toes are so joined.

The nest is a depression in the sand lined with leaves. The eggs are from two to four in number, of a drab color, with black spots and blotches, and one and one-fourth by one inch in size.

They breed in the far north and spend the winter in the West Indies and further south. They are very common in New Jersey along the coast between May 10 and June 1, and again between July 19 and September 15.

The birds are generally found in groups and look for their food along sandy beaches, mud flats and marshes, picking up small insects and shellfish; in the interior they are found along ponds, lakes and the shores of rivers. Their flesh, when not of a sedgy flavor owing to too much sea food, is considered palatable.

Plover, Upland. See Bartramian Sandpiper.

Poke. See Green Heron.

Quail. See Bob White.

Quabird. See Night Heron. 
Quawk. See Night Heron.

Rail, Black.-This bird is a very rare transient in New Jersey, a few specimens having been taken at times in August and September. They formerly bred in Cape May county. Their breeding location is farther north and they spend their winters in the West Indies and northern South America. The eggs are ten in number, white with brown spots, and one inch by four-fifths of an inch in size. The bird is five inches in length, the head and breast being slate color; back, wings and tail, dark brown, transversely barred with rows of white spots; belly, slate color, with white bars and spots.

Rail, Bhe. See Florida Gallinule.

Rail, Carolina. See Sora.

Rail, Clapper, INud Hen, Salt Water JIarsh Hen, Meadow Clapper, or Big Rail.-The Mud Hen of the New Jersey laws.-Length, fourteen inches; extent, eighteen inches; bill, two and two-fifths inches long, slightly curved, pointed, grooved and of a reddish brown color; above, greenish gray, feathers rather darker in the center; under surface, dull white, tinged with buff on the neck and sides, flanks and feathers under the tail barred with white; long wing feathers, dark brown, lining of the wing barred with white. The males and females are nearly alike, the plumage of the female not being so distinctly marked as that of the male. The young birds of the first year are browner and richer in color than the old birds.

The nest is built in the salt meadows; it is lined with dry grass, arched and knit together at the top in order to conceal it. Mating begins about the middle of May. The eggs are generally ten in number, of a pale clay color, sprinkled with small spots of reddish purple, obtuse at the small end, and measure one and a half inches by one inch. 
The birds breed along the Atlantic coast as far north as Massachusetts. They arrive in New Jersey from the south about the middle of April and leave at the approach of cold weather in October or November, a few remaining in the southern part of the state if the season is not very cold.

Their cry is generally heard at night, about as unmusical as that of the Guinea Fowl, which it resembles.

They feed on shell-fish, snails and small crabs and their flesh has a sedgy flavor.

Rai, , King, or Marsh Hen.-Length, fifteen inches; extent, eighteen inches; bill, two and two-fifths inches. This is the fresh-water congener of the Clapper Rail, and in size and pattern of coloration is exactly like it, differing only in its tints. Above it is rich brown, each feather centrally streaked with black, except on the head, where the color is uniform dark brown, and the wings, which are chestnut brown; under surface of the body, bright rusty; throat and center of belly, white; flanks and hinder part of belly, barred with black and white.

The nest is built of grasses in fresh water marshes; the eggs are from seven to twelve in number, of a yellowish white, with brown spots, and one and two-thirds by one and one-fifth inches in size.

They breed northward to the Middle States and have been known to breed in New Jersey, where they are, however, not very common and found only in summer. They spend the winter in the southern part of the United States.

\section{Rail, V’irginia, Little Red Rail, or Fresh Water} Moud Hen.-Length, ten inches; extent, fourteen inches; bill, one and a half inches, dusky red. This bird is almost an exact miniature of the King Rail, the tints of its plumage being exactly the same except that the present species has the sides of the head a bluish lead color. The 
female is a little paler than the male and the young frequently have more or less black mixed with the rusty color of the breast.

The nest is built of old wet grass and rushes in the bottom of a tuft of grass. There are two broods a year, one early in May and another late in June. The eggs are from six to ten in number; they are one and one-fifth by three-quarters of an inch in size, of a dirty white or pale cream, sprınkled with spots of reddish or pale purple, these spots being more numerous near the larger end.

The birds breed in North America as far north as Hudson's Bay, frequenting the fresh marshes near the coast. They arrive in New Jersey about the first of May and leave in October, being seen very rarely in winter.

Their food consists of snails, worms, larvae of insects, which they take from the mud, together with some vegetable matter.

Rail, Yellow.-This bird is a rare transient in New Jersey, although a few specimens are occasionally taken, generally in the fall. They breed in the northern part of the United States and as far north as Hudson's Bay and in the winter migrate south as far as Cuba. The length of the bird is seven inches and the bill is half an inch in length. The upper parts are black, mottled with light yellow and transversely barred with narrow white bars; breast, buff; belly, whitish; lower belly and flanks, dark brown with white bars. They nest on the ground in marshes; the eggs number from six to nine, are of a light yellow, with numerous spots of brown, and one and onefifth by four-fifths of an inch in size.

\section{Rain Crow. See Cuckoo.}

Raven.-Length, from twenty-two to twenty-six inches; extent about four feet; bill, a little over an inch in length, large and strong, and of a shining black. The plumage of the bird is a deep black, with steel-blue 
reflections, being less glossy on the under parts; feathers of the neck, rather long and pointed.

The nest is a compact structure, built on trees and cliffs; it is made of sticks lined with grass and is used year after year, additions being occasionally made to it. The eggs are from two to seven in number, of a pale blue green with brown spots, and two inches by one and onethird in size.

The bird breeds throughout the whole of the northern and eastern part of the United States, but is rather scarce in New Jersey, some being still found breeding in the cedar swamps in the lower part of the state and solitary specimens being observed occasionally along the sea coast.

The principal food of the bird is carrion of all kinds, but it also devours worms, reptiles and shellfish, and has no hesitation about robbing birds' nests.

\section{Red Crossbill. See American Crossbill.}

Redhead. See Redhead Duck.

\section{Redpoll, Redpoll Finch, or Redpoll Limmet.-} Length, five and one-third inches; extent, eight and a half inches; bill, one-fourth of an inch long, sharply pointed, pale yellow, ridged with horn color, a tuft of feathers projecting forward over the nostrils; feathers of the upper surface, dusky in the center, bordered with buff and dull white, producing a streaked appearance; rump, lighter and often tinged with pink; crown, brilliant glnssy crimson; wings and tail, dusky brown, slightly edged with white; under surface, white, the sides streaked with dusky, the throat dull black, and more or less rosy pink on the breast. The females have little or no pink below, but the males vary some, having but little, while others have half the lower surface of this color; tail, slightly forked; feet, black.

The nest is built in a low tree or tuft of grass, of moss and grass, lined with hairs, feathers and plant down. 
The eggs are from four to six in number, white, with a greenish or bluish tinge and with reddish brown spots, two-thirds by half an inch in size.

The birds breed in northern British America and in winter frequently find their way. south as far as New Jersey, generally occurring in considerable flocks. The general supposition is that they come hither only when their food supply fails in the north on account of too much snow. They are very cheerful and their bright crimson agreeably relieves the sombre landscape of winter. They feed on seeds, generally in orchards or gardens.

Redstart.-Length, five and two-fifths inches; extent, six and one-fourth inches; bill, one-fourth of an inch in length, black, with bristles at the base; entire head, back and breast, glossy blue-black; belly, white, a patch on each side of the breast brilliant salmon red; wings, dull black, crossed by a salmon red bar; central pair of tail feathers, black, others salmon, except the terminal third, which is black. The female is grayish olive above and dull white beneath, with all the salmon markings replaced by yellow, the band on the wing being less in extent. Young males apparently do not acquire their full dress until their second spring; their plumage in the first spring is like that of the female, but with more or less black feathers on the head and breast.

The nest is built in the crotch of a sapling or in a low bush; it is a carefully constructed contrivance, made of bark and leaf stalks, interwoven with plant down and flax, and lined with tendrils and fine roots. The eggs are either four or five in number, of a grayish white, sometimes tinged with blue, and with brown spots, two-thirds by one-half an inch in size.

The birds breed in eastern North America, some in New Jersey, but comparatively few in the southern part of the state. They are abundant in this state during migrations, between April 30 and May 20, and again be- 
tween August 5 and October 5. They spend the winter in the West Indies, Mexico and southward.

Their song is likened by Mr. Chapman to ching, ching, chee; ser-wee, swee, swee-e-e.

Their food is insects of the smaller kind, including gnats and caterpillars.

Reedbird. See Bobolink.

Ricebird. See Bobolink.

Rice Bunting. See Bobolink.

Ringmeck. See Semi-palmated Plover.

Ring-tailed .Marlin. See Hudsonian Godwit.

Robin.-Length, nine and a half inches; extent, thirteen inches; the bill is strong, an inch long, and of a bright yellow, although sometimes black or dusky near the tip of the upper mandible; tail and top and sides of the head, black; back and rump, ash color; wings, black, edged with light ash; the inner tips of the two exterior tail feathers are white; three small spots of white border the eye; the throat is white, streaked with black; the whole of the rest of the under surface down as far as the thighs is of a very dark brown; middle of belly, white; legs, dark brown; claws, black and strong. The colors of the female are all rather lighter and paler, especially below. The young bird is speckled with white above and the whole lower surface is marked with round black spots.

The nest is built in the crotch of a fruit or shade tree, from five to thirty feet up, or sometimes in a hedge or strong vine; it is composed of coarse grasses, leaves and small roots, with an inner wall of fine grasses and mud. The eggs are from three to five in number, plain greenish 


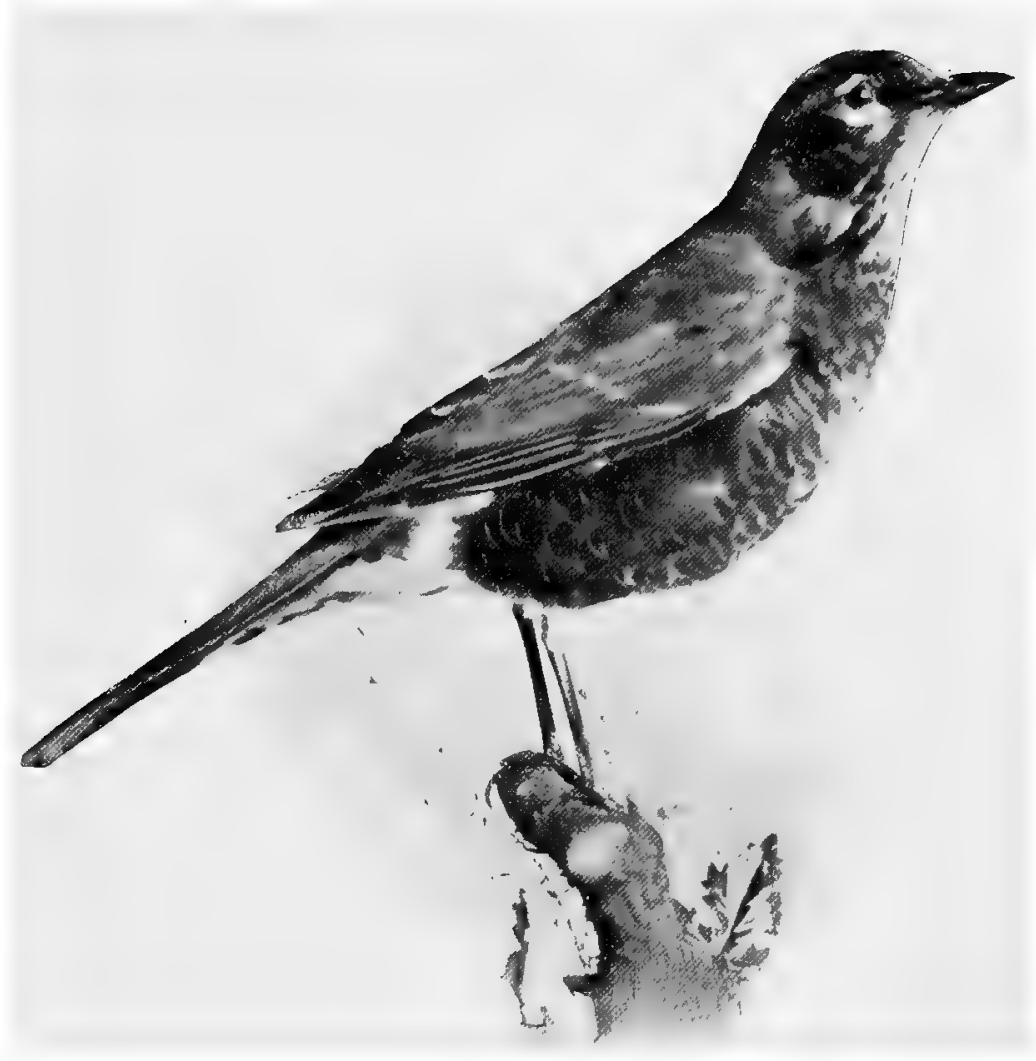

ROBIN. 
blue, and one and one-tenth by four-fifths of an inch in size. There are two broods each year.

The Robin breeds in Eastern North America and in the upper parts of the Southern States; it is found in the United States east of the Rocky Mountains, in eastern Mexico and in Alaska. It winters mainly in the southern part of the Middle States. The birds arrive in New Jersey about the middle of March and leave here shortly after the first of November; some, however, remain here all winter.

Its song is a loud, clear, musical warble. Its call note, with which it frequently warns other birds of approaching danger, sounds like the word quick.

About one-half of the food of the Robin is composed of insects, principally March-flies,' with a good percentage of grasshoppers, bugs, spiders, wasps, ants, and canker worms. The fruit it devours is principally wild, it having been estimated that only five per cent. of the fruit it eats is grown by man. Professor Forbes asks this question: "Will the destruction of seventeen quarts of average caterpillars, including at least eight quarts of cut worms, pay for twenty-four quarts of cherries, blackberries, currants and grapes?" Mr. Bruner says: "He is a poor business man who pays $\$ 10$ for that which he knows must later be sold for fifteen cents or less. Yet I have known of instances where a Robin that had saved from ten to fifteen bushels of apples that were worth a dollar a bushel, by clearing the tree from canker worms in the spring, was shot when he simply pecked one of the apples that he had saved for the grateful or ungrateful fruitgrower."

Robin, Golden. See Baltimore Oriole.

Robin, Ground. See Chewink.

Robin, Swamp. See Chewink. 
Saddle-back. See Black-backed Gull.

\section{Sanderling, Rudaly Plover, or Surf Snipe.-} Length, eight inches; extent, fifteen inches; bill, one inch, black; head, rusty, with black centres to the feathers; back, black centered feathers, edged with rusty brown and ashy; breast, rusty brown, spotted with black; belly, white; sides, white; tail, black and white; wings, dark slaty brown, with white bar; legs and feet, black; a mark distinguishing this bird from Snipes and Sandpipers is the fact that it has only three toes. In fall and winter the upper parts are a pale gray with black-centered feathers and the entire under parts are white.

The nest is made of hay and decayed leaves. The eggs are four in number, of a brownish olive with spots of dark olive brown, and one and two-fifths by nine-tenths of an inch in size.

The birds breed in the far north and spend the winter in the southern Atlantic states and South America. They are abundant in New Jersey from April 18 to June 1 and again from September 14 to October 15, being generally found along the sea coast and rarely on mud flats near bays.

Their food consists of minute shellfish and insects left by the tide.

Sand, Ox-Eye. See Semi-palmated Sandpiper.

\section{Sandpiper, Bartramian, Grass Plover, Upland} Plover, or Field Plover.-Length, twelve inches; extent, twenty-one inches. The bill is an inch and a half long, slightly bent downwards, wrinkled at the base, the upper part black on its ridge, the lower as well as the edge of the upper, a fine yellow; front, stripe over the eye, neck and breast, pale brown, marked with small streaks of black, which on the lower part of the breast assume the form of arrowheads; crown, black, the plumage thickly skirted with white; chin and whole belly, 
white; hind head and neck above, brown, minutely streaked with black; back, black, the feathers slightly skirted with brown; long wing feathers, black, barred with white on the inner webs; rump, deep brown black, slightly bordered with white; tail, tapering, of a pale brown orange, barred with black, the middle feather centered with dusky; legs, yellow, tinged with green, the outer toe joined to the middle one by a membrane; lining of wings, barred with black and white; eye, very large. The male and female are nearly alike.

The nest is a mere depression in the ground, lined with grass, straw and tendriss. The eggs are generally four in number, of a clay color, spotted all over with brown and purplish gray, and one and three-fourths by one and onefourth inches in size.

The birds breed in the United States from Virginia northward and spend the winter in South America. They arrive in New Jersey during the latter part of April and remain until the middle of September.

Their cry is a loud, long, soft whistle, the alarm note, $q u i p-i p-i p$-ip, quip-ip ip-ip, at other times uttering a chr-r-r-r-ee-e-e-e-e-e-oo-0o-o-o-oo.

Their food consists of insects and they destroy a great many grasshoppers and beetles and occasionally take a few berries.

\section{Sandpiper, Least, Peep, or Meadow Ox-eye.-} Length, five and a half to six inches; extent, twelve inches; bill, three-fourths of an inch, black; feathers on the upper surface of the body and head, black centrally, broadly bordered wilh buff and gray; long wing feathers, dark brown; tail, light grayish brown, central pair dusky; below, breast and neck white, somewhat suffused with gray, and each feather with a central dusky streak; rest of under parts, white; legs and feet, black. In the winter there is less gray and more white in the plumage.

The nest is a depression in dry moss lined with a little 
grass. The eggs are generally four in number, of a gray or yellow color, with brown spots most numerous at the large end.

The birds breed in the far north and go in winter as far south as South America. They are very alundant along the New Jersey coast in the early part of May and again from July 15 to September 15, and are also found in marshy meadows, shores of creeks, rivers and lakes.

Their food is composed of insects and small shellfish.

\section{Sandpiper, Pectoral, Frieker, or Grass Snipe.} -Length, eight and a half inches, the female being a little larger; bill, yellow at the base, the rest black, one and one-tenth inches in length; above, brownish buff, streaked with black; rump, uniform black or dark brown; tail feathers, light grayish brown, center pair darker; long wing feathers, dark brown; throat and belly, white; breast, sides of head and neck, buffish or grayish white, streaked with dusky. Young birds have the backs darker, with less buff edgings to the feathers; legs and feet, yellowish. In winter there are no brown tints on the upper parts and the breast is of a soiled white.

The nest is built in a tuft of grass. The eggs are generally four in number, of a greenish drab with brown spots, and one and a half by one inch in size.

The birds breed in the far north and spend the winter in South America. "They are regular transients in New Jersey, numerous along the coast, but also occasionally appearing in the interior, generally in small parties. They fly north during the month of April, but are more numerous in New Jersey during the fall migration, from August 15 to October 1.

Their food cousists of aquatic insects and small shellfish.

Samdpiper, Hed-backed, Huackbreast, Leadback, or Wointer Smipe.-Length, eight and a half inches; extent, fifteen inches; bill, slightly curved, black, 
one and a half inches long; above, rusty red, each feather centrally streaked with black; hind neck, gray; wings and tail, grayish brown; chin and throat, white; breast, sides of head, neck and body, white, streaked with dusky; whole center of belly, black, feathers often tipped with white; legs and feet, black. In fall and winter the plumage above is gray with brown streaks; the breast is light gray with small brown streaks and the under parts are white.

The nest is built of grass on dry knolls about June 1. The eggs are three or four in number, of a pale green or brownish gray, with brown spots, and one and a half by one inch in size.

The birds breed in the far north and spend the winter in the South Atlantic and Gulf coast states, some as far north as Cape May county, New Jersey. They are abundant during migrations, April 17 to May 20, and again in September.

Their food consists of worms, insects and small shellfish.

\section{Sandpiper, Semi-palmated, Peep, or Sand ox-} eye.-Length, five and a quarter to six and a half inches; extent, from eleven to thirteen inches; bill, one inch long, black; line over the eye, white; throat, white; head and back, black or dark slate, edged with gray and buff; belly and sides, white; breast, white, streaked with dusky; tail and wings, brown; legs, dark ash; feet, dark ash, half webbed. In winter the breast is of a lighter gray and the streaks are indistinct or wanting. This bird closely resembles the Least Sandpiper, with which it constantly associates, but is at once distinguished by the webbing at the base of toes, which is lacking in the latter species.

The nest is a mere depression in grass; the eggs are generally four in number, variable in color from a gray to a light yellow, with reddish spots, and one and one-fourth by nine-tenths of an inch in size. 
The birds breed in the far north and spend the winter in the south from the West Indies to South America. They are very abundant along the New Jersey coast between May 9 and June 1 and again from July 15 to September 1.5, but are rarely seen in the interior.

Their food consists of insects and small shellfish.

Sandpiper, Solitary.-Length, eight and a half inches; extent, fifteen inches. The bill is one and a quarter inches in length, dusky; line over the eye, chin and belly, white; breast, white, spotted with olive brown; upper parts, dark olive brown, each feather marked along the edges with small round spots of white; long wing feathers, uniform, nearly black; tail, slightly rounded, the five exterior feathers on each side white, broadly barred with black, the two middle ones plain olive brown, with small white marginal spots; feathers covering the base of the tail transversely banded with black and white; legs, long, slender, dusky green. The male and female are alike in color.

Although this bird is a common transient in New Jersey and is distributed over a large part of the United States, very little is known concerning its breeding; it does not, however, remain in this state through the summer. The eggs are said to be light luff, spotted with various shades of brown, and one and one-third by one inch in size.

The bird passes through New Jersey between April 25 and May 1.5, and again between September 15 and October 20. It winters in the Southern States.

Its food is composed of insects, frequently taken on the wing, larvae, worms and small shellfish.

\section{Sandpiper, spotted, Teetering Snipe, or Peet-} weet.-Length, seven and a half inches; extent, thirteen inches; bill, an inch long, straight, the tip and upper part dusky, the lower orange; stripe over eye and lower eyelid, white; whole upper parts, an olive brown with green- 
ish reflections, each feather marked with waving spots of black; long wing feathers, dark brown, the middle one with white tips; tail, rounded, the outer feathers mostly white, the others olive brown, all barrel with black; whole lower parts, marked with round spots of black, smaller and thicker on the throat and breast, larger and thinner as they descend to the tail; legs, a yellow clay color; claws, black. The fenale is as thickly spotted below as the male, but the young birds of both sexes are white below, slightly suffused with gray on the breast, but they are also barred across with narrow buff lines above in addition to the black bars.

The nest is situated in open spots near the borders of streams and ponds and in fields among the stubble; it is built of straws and grasses. The eggs are generally four in number, of a creamy buff or light drab, with brown spots becoming larger and confluent at the larger end, one and one-fourth by one inch in size.

The birds breed throughout the whole of North America, arriving in New Jersey from the south about the end of April and leaving about the first of October. They are very numerous throughout the state and their comical antics afford a great deal of amusement to persons watching them along the shores of fresh water streanıs and ponds.

Their food is insects and larvae.

Samdpiper, W'hite-rumped.-Length, seven and a half inches; extent, thirteen inches; bill, one inch, greenish black; above, ashy brown, feathers broadly centered with black and somewhat edged with rusty; rump, white; tail. blackish brown; wings, slaty brown; below, including sides of head and neck, white, spotted with black or dark brown as far as the forebelly and sides; belly, white; Iegs and feet, greenish black. In winter the upper parts are a brownish gray and the markings generally less distinct.

The nest is a depression in the ground, lined with 
leaves. The eggs are either three or four in number, of a light brownish drab, with black and brownish spots and blotches becoming confluent at the larger end, and one and one third by one inch in size.

The birds breed in the far north and spend the winter in eastern South America. They are never very common in New Jersey and appear only during the migrations in the early part of May and again from July 15 to September 15. They frequent the sea coast, but are also seen along muddy flats and in shallow pools.

Their food consists of aquatic insects and small shellfish.

\section{Sapsucker, or Yellow-bellied Woodpecker.-} Length, eight and a half inches; extent, fifteen inches; bill, nine-tenths of an inch. The whole crown is a rich and deep scarlet, bordered' with black on each side and behind, forming a slight crest, which the bird frequently erects; from the nostrils, which are thickly covered with hairs, a narrow strip of white runs downward, curving around the breast, mixing with the yellowish white on the lower parts of the breast; throat, the same deep scarlet as the crown, bordered with black and spreading into a broad rounding patch on the breast, a line of white and below it another of black proceed, the first from the upper part of the eye, the other from the posterior part of the eye, and both lose themselves on the neck and the back; back, dusty yellow, sprinkled and waved with black; wings, black, with large spots of white; rump, white, bordered with black; belly, yellow, sides under the wings, more dusky yellow, marked with long arrowheads of black; legs and feet, greenish blue; tail, black, the two outer feathers on each side tipped with white, the next totally black, the fourth edged on its inner vane half way down with white, the middle one white on its interior vane and spotted with black. The female differs in having the throat white and the crown black, while the 
young have the whole throat and breast brown, barred transversely with black; others show the brighter colors of the adults appearing on the crown and throat.

The birds breed northward from Massachusetts and perhaps also in the mountains of northern New Jersey, and occasionally they winter in the lower part of the state. They arrive here from the south about the middle of March, passing further north about the middle of April; in the fall they return between september 10 and October 20 .

Their cry is a clear note, repeated five or six times, or a low, snarling cry like the mew of a cat.

There is little doult that these birds do far more mischief than their insect-eating propensities can counterbalance. They bore holes into trees and feed on the exuding sap; after having taken their fill they retire and await the gathering of insects attracted by the sap, when they return and feed on the insects. The holes they bore are generally square and by girdling a tree with them they frequently cause the destruction of the tree.

\section{Scaup, Greater, Bhuebill Duck, Broadbill, or} Blackhead.-Length, eighteen and a half inches; extent, twenty-nine inches; the female is a trifle smaller; bill, one and two-thirds inches, heavy, broad, bluish; head, neck and whole breast, black, the top and sides of the head frequently with greenish reflections; upper back, black; lower back, fine wavy black and white bars; belly and sides, white, on the lower parts with indistinct wavy black bars; tail, black; wings white, slaty and black; legs, bluish; feet, black. The female has brown instead of black on the upper parts and the sides are a grayish brown with waves of white. The birds nest on the ground in marshes or similar places. The eggs are from six to ten in number, of a pale yellow, two and a half by one and three-fourths inches in size. The birds breed in the far north and in the winter go southward to Florida. 
They are very common in New Jersey in bays and rivers, especially where the water is brackish. They remain here from the first of November to the first of April and are less common in midwinter when the bays and rivers are frozen over. Their cry resembles the word scaup; hence their common name. They feed on mollusks and seeds and their flesh is considered rery palatable.

\section{Scaup, Lesser, Little Blackhead, Little Bluebiu,} or Creek Broadbill.-This duck is very similar to the foregoing but about two inches smaller. It has purplish instead of greenish reflections about the head and the sides are strongly marked with black waves.

Scissors-biu. See Black Skimmer.

Scoter, American, or Black Coot.-Length, nineteen inches; extent, thirty-one inches; bill, one and fourth-fifths inches. The entire plumage is black, on the neck and back frequently more or less glossy. The bill is orange at the base. The female is brown, lighter on head and neck. Its nest is found on the ground, near water. The eggs are from six to ten in number, of a pale yellow, two and one-half by one and three-fourths inches in size. It breeds in the far north and in the winter travels south as far as New Jersey, being common in winter off the coast and seldom found in rivers. Its food is composed of mussels, clams and scollops and its flesh is tough and inedible.

Scoter, Surr, or Sea Coot.-Similar to the foregoing, one inch longer, and with a square white mark on the crown and a triangular white mark on the back of the neck. The female has the upper parts dark brown, the throat, the breast, sides and lower belly gray and the upper belly white They nest in tall grass near water. The eggs are from five to eight in number, of a pale yellow, and two and oue-half by one and three-fourths 
inches in size. They breed in the far north and in the winter go south as far as the Carolinas. They are common off the New Jersey coast from October to late in April and are seen occasionally on large rivers. The flesh is tough and inedible.

\section{Scoter, W'hite-winged, or W'hite-winged Coot.-}

Similar to the American Scotrr, but three inches longer; bill, one and a half inches long, orange black. There is a white spot below the eye and a large white spot on each wing. The female is a slaty brown, lighter below and with white feathers near the base of the bill. They nest on the ground, under bushes, frequently some distance from water. The eggs are from six to ten in number, of a pale yellow, and two and one-third by one and four-fifths inches in size. They breed in the far north and in winter travel souch as far as Chesapeake bay. They are seen off the coast of New Jersey, more frequently in the middle of winter. Their flesh is tough and inedible.

Sea Dove. See Little Auk.

Shag. See Cormorant.

Shearwater, Sooty, or Black Hagdon.-This is a strictly sea bird, seen frequently on the fishing grounds off the New Jersey coast, especially in winter. It is a swift flyer and dives into the water for its prey; it is particularly active during storms when the agitated surface of the water gives it better opportunities for seeing its prey. It occasionally visits the shore. It is about seventeen inches in length and its bill is one and two-thirds inches in length, with nostrils tubular, like those of the Petrel; whole plumage sooty gray, somewhat lighter below. Nothing is known about its breeding.

Shelldrake. See American Merganser and also Redbreasted Merganser. 
Shrike, Loggerhead.-Length, nine inches; extent, thirteen inches; bill, one-third of an inch, black; head and back, gray; breast, soiled white, sometimes with slight waves of dark gray; belly and throat, whibe; tail, black, - white tips, the four middle feathers being wholly black. The female is darker.

The nest is found in hedges or low trees. The eggs are from three to five in number, of a dirty white, with brown spots, one by three-fourths of an inch in size. It breeds and is distributed through the southern United States as far northward as Virginia and a few are seen in summer in Cape May County, N. J. Stragglers are occasionally taken in fall and winter at various points in the state. Its song is a succession of gurgles and whistles, is very unmusical and harsh, but it makes up in quantity what it lacks in quality. The food of these birds consists of grasshoppers, small snakes and lizards.

Shrike, Northern, or Butcher Bird.-Length, ten inches; extent, thirteen inches; bill, half an inch, hooked and strong; head, dark gray, with a black bar on each side from behind the eye; back, gray; breast and sides, light gray, with waves of darker gray; belly. white, with scarcely any wavy bars; tail, black, tipped with white, center pair of feathers entirely black; wings, black with white tips and a large white bar across the inner webs of the feathers; legs and feet, bluish black. The female is brighter gray above.

The birds nest in low trees or bushes, the nests being made of sticks with a superstructure of grass, tendrils, wool, etc. The eggs are from three to five in number, of a soiled white, with brown spots, and one inch by threefourths in size.

They breed from the northern border of the United States northward and in winter go south as far as the Potomac valley. At times they are rare in New Jersey, but in very severe seasons they are plentiful. 


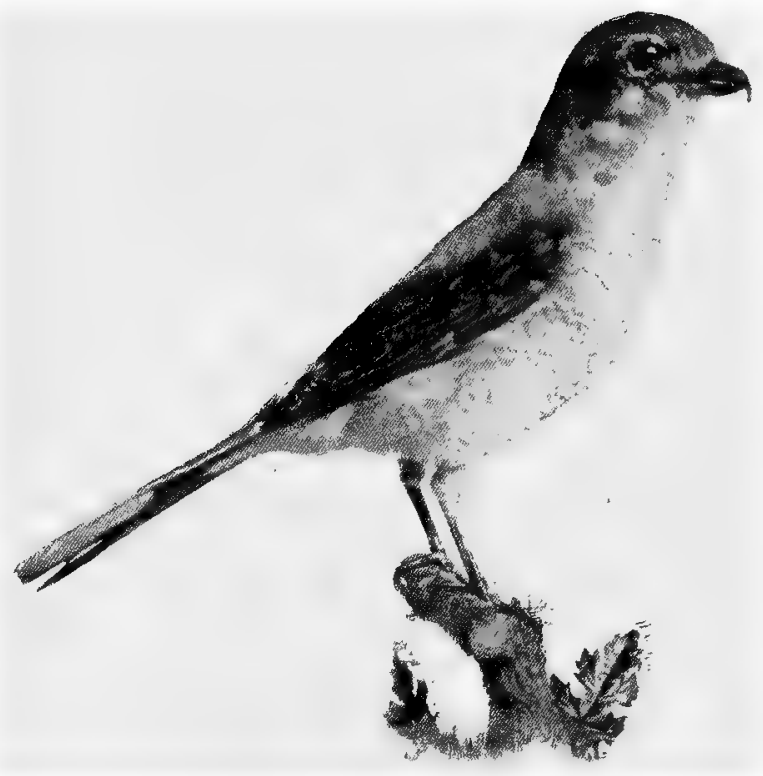

NORTHERN SHRIKE. 


$$
=
$$


The song of this bird is an improvement on that of the foregoing and somewhat resembles the tune of a Catbird.

The food consists of grasshoppers, beetles and large insects, but principally of English Sparrows. It obtains its name of Butcher Bird from a habit it shares with the preceding species of impaling its prey on thorns, to remain there until wanted.

Siskin, Pine. See Pine Finch.

skimmer, Black, or Scissors-bill.--Length, eighteen inches; extent, three feet, eight inches; upper bill, three, lower nearly four inches, compressed almost flat, resembling the blades of shears. The female is somewhat smaller. The forehead, sides of the neck and upper parts are white, the upper parts and the wings black, and the tail black, broadly edged with white and brown. The nest is a depression in the beach. The eggs are either three or four in number, white or cream in color, and one and three-fourths by one and one-third inches in size. It was formerly plentiful along the sea coast of New Jersey, but it is now rare. In winter it migrates to South America. Its food is small fish, etc., which it picks out of the water.

Smipe, English. See Wilson's Snipe.

Snipe, Grass. See Pectoral Sandpiper.

Snipe, Gray. See Knot.

Smipe, Red-breasted. See Dowitcher.

Snipe, Robin. See Knot.

Smipe, Stone. See Greater Yellowlegs.

Smipe, Surf. See Sanderling.

Snipe, Teetering. See Spotted Sandpiper.

Smipe, W'ilson's, or English Smipe._Length eleven 
inches; extent, seventeen inches; the bill is more than two and a half inches long, fluted lengthwise, of a brown color and black towards the tip, where it is very smooth while the bird is alive, but soon after it is killed becomes dimpled like the end of a thimble; crown, black, divided by an irregular line of pale brown; another and broader one of the same tint passes over each eye; from the bill to the eye there is a narrow dusky line; neck and upper part of breast, pale brown, variegatud with touches of white and dusky; chin, pale; back, dsep velvety black, marbled with waving lines of brown and broadly edged with buffy white; wings, plain dusky; tail rounded, deep black, ending in a bar of bright rusty brown, crossed with a narrow waving line of black and tipped with white; belly, white; sides barred with dusky; legs and feet, pale ashy green; sometimes the whole thighs are barred with dusky and white. The female differs in being more olscure in her colors, the white on the back being less pure and the black not so dee!!.

The nests are mere depressions in the grass and bog. The eggs are either three or four in number, of a clay or brownish ashy color, with chocolate spots, more numerous near the large end, and one and three-fifths by one and two-fifths inches in size. They are placed with the small end downward in the nest.

The birds breed principally northward of New Jersey; it is claimed by many ornithologists that a few remain in New Jersey to breed. Some certainly do remain through the summer, but they are iu all probability either crippled or improperly developed, thus being prevented from pursuing their flight further north ward. The birds generally reach New Jersey between March (2) and May 10; their return flight occurs in September and October.

These brrds at times make a noise which in the distance sounds like the bleating of a goat and then again like the drumming of a partridge. During the nesting season their cry is $k u k-k u k-k u k-k u k-k u k$. They rise from the 


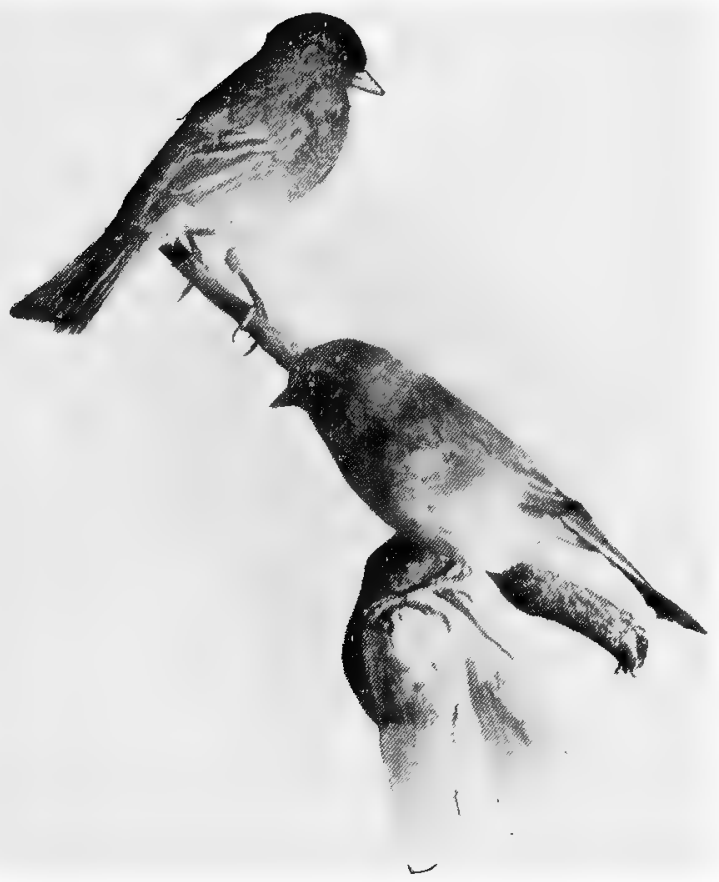

SNOWBIRDS. 

ground with a squeak sounding like scaipe, and as they rise into the air, "now with continued beating of the wings," says Audubon, "now in short sailings, until more than a hundred yards high, when they whirl around each other with extreme velocity, and dance as it were to their own music; or at this juncture, and for the space of four or five minutes, you hear rolling notes mingled together, each more or less distinct, perhaps according to the state of the atmosphere. The sounds produced are extremely pleasing, though they fall faintly on the ear."

The food of these birds consists of insects and worms, taken principally at night.

Snipe, Winter. See Red-backed Sandpiper.

Snowbird, or Jumco.-Length, six and a quarter inches; extent, nine inches; bill, two-fifths of an inch, flesh color, dusky at tip; head, back, throat, breast and sides of the body, deep slate; lower breast and belly, white; tail, a little forked, deep slate, with the two outer feathers white and the next spotted with white; wings, deep slate; legs, reddish flesh. In the female and young the upper parts are somewhat suffused with brown and the throat and breast are paler.

The nests are built of grass, moss and small roots, on or near the ground. The eggs are either four or five in number, of a white, with at times a bluish tinge, and three-fourths by four-fifths of an inch in size.

The birds breed from Maine to Alaska and southward along the Alleghanies, and in the winter come down to the eastern United States, being abuudant in New Jersey between October 1 and April 15.

Their note is a tsip and their song, heard in New Jersey only in the early spring, a faint warble and trill.

The food of these birds consists principally of seeds of weeds, although they also frequent barnyards and in extreme cold weather, when everything outdoors is frozen 
up and covered with snow, come to the kitchen yard apparently begging for food.

Snowftake, or Snow Bunting.-Length, six and three-fourths inches; extent, twelve inches; bill, twofifths of an inch, black; head, white; breast, belly and sides, white; tail and wings, white and black; back, black; rump, white; feet, black. In the female the upper parts are streaked with black and the wings are dark slate. In winter all the feathers of the upper surface, as well as the breast and sides of the head, are edged with rusty brown in both male and female.

The nest is built on the ground, of grasses, roots and moss, lined with feathers. The eggs are from four to seven in number, of a pale bluish white, with brown spots, and four-fifths by one-third of an inch in size.

The birds breed in the far north and in the winter migrate to the northern United States, occasionally coming south as far as New Jersey, where, however, they are seldom seen excepting in severe winters and when there is a great deal of snow.

Thoreau says that their song is a "soft, rippling note."

The food of these birds consists of the seeds of plants, especially of aquatic plants, and of minute shellfish adhering to the leaves.

Sora, or Carolima Rail.-Length, nine inches; extent, fourteen inches. The bill is four-fifths of an inch in length, yellow, blackish at the point; the front, crown, chin and stripe down the throat, black; line over the eye, cheeks and breast, light ash; sides of the crown, neck and upper parts generally olive brown, streaked with black, and also with lines of pure white, the feathers being centered with black and edged with white; these touches of white are shorter near the shoulder of the wing, lengthening as they descend; wings, plain olive brown, with a few of the upper feathers streaked with black and long lines of white; tail, pointed, dusky olive brown, centered 


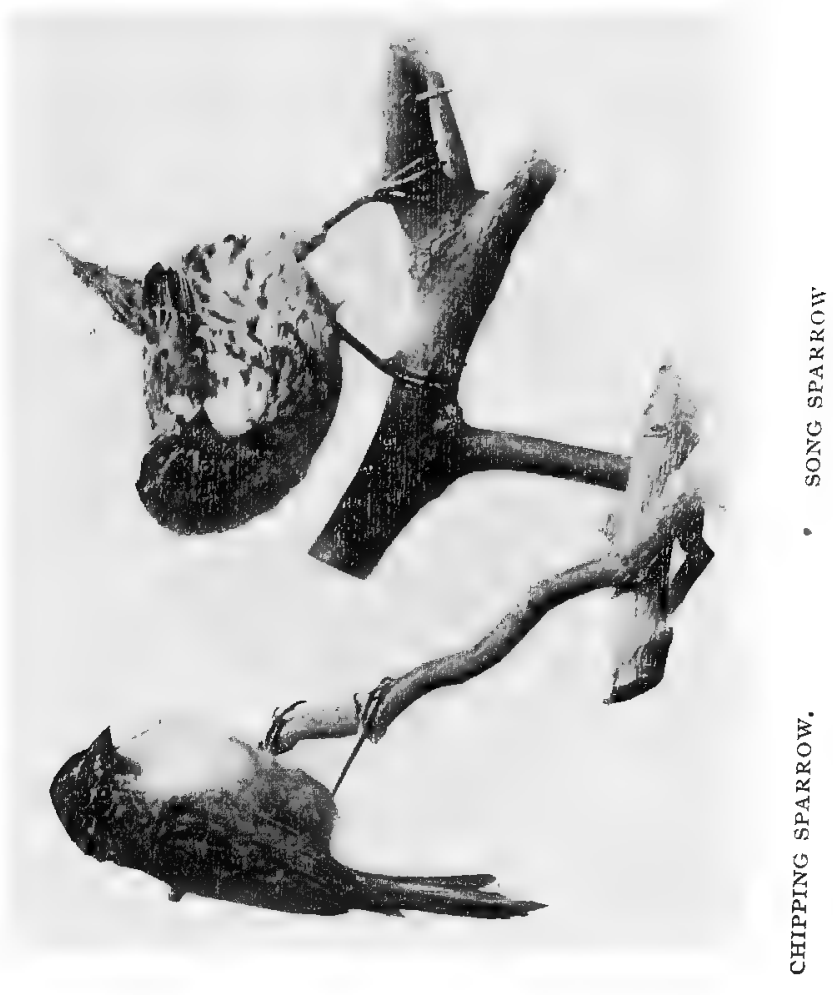




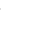


with black, the four middle feathers bordered for half their length with lines of white; lower part of the breast lined with semi-circular lines of white on a light ash ground; center of belly, white; sides under the wings, deep olive, broadly barred with black and white; legs, feet and naked parts of the thighs, yellowish green. The females and young of the third season have the throat white, the breast pale brown and little or no black on the head.

The birds build their nests in May of marsh grass in reeds near the water or in swampy sinkholes of quicksand meadows. The eggs are from eight to fifteen in number, of a creamy white, with brown spots, and one and a quarter inches by nine-tenths in size.

The cry of the birds is crek-crek, or kerwee, kerwee, generally heard at sunset or in the evening.

Their food consists of small shellfish, worms and some vegetable matter.

south-southerly. See Old Squaw Duck.

Sparrow, Chipping, Chippy, or Hairbird.Length, five and one-third inches, extent, eight inches; bill, one-third of an inch, black, lower mandible yellow at the base; forehead, black, a short gray line in the middle; top of head, chestuut brown, a gray line over the eye and a black line behind it; throat, white; back, streaked with black, light brown and chestnut; belly, white; rump, dark ash; tail, dull brown, edged slightly with whitish, slightly forked; wings, dull brown, edged with buff and chestnut; legs and feet, pale flesh color. The female has less black on the forehead and the brown is of a duller cast, while the young birds have the crown striped with black and during their first summer are streaked with black below.

The nest is a well-built contrivance, generally found near human habitations, in the vines on the piazza or the 
hedges of the garden, or in trees and bushes from five to twenty feet up. It is built of grass, twigs and tendrils and lined with horsehair. The eggs are either four or five in number, light greenish blue with brown spots, the latter more numerous near the large end, and threefourths by one-half an inch in size.

The birds breed throughout eastern North America and in winter migrate to the Southern States; they are very plentiful in New Jersey hetween April 1 and October 20.

Its call note is chip and its song chippy-chippy-chippychippy.

Its food consists of seeds, bread crumbs, etc.

\section{Sparrow, English, House Sparrow, Gamin,} Tramp, or Hoodlum. - This bird is so well known that little space need be devoted to its description. In the male the crown is gray, bordered with brown from the eye backwards; the throat is black in the middle and white on the sides; the back is streaked black and brown; the breast is black; belly and sides gray and the rump ashy; the tail gray, the wings brown and white and the feet brown. In the female the head and rump are of a grayish brown; the back is streaked with black and a deep dirty yellow; the sides and whole under surface are pale grayish, with a brown tinge.

The lirds build their nests of almost any material they can get hold of in any available place; the eggs are from four to eight in number, one and five-sixths by twothirds of an inch in size, and generally of a white color with brown markings.

The English Sparrow was introduced into the United States in 1852 by the Brooklyn Institute, eight pairs being imported. These did not thrive and members of the Institute and others subscribed to a fund of $\$ 200$ for the acquirement of more. The second lot arrived in the latter part of the year and of these fifty were let loose at the Narrows in New York harbor; the rest were placed in the 
tower of the chapel of Greenwood cemetery. They were released in the spring of 1853 and did well. From that time to the year 1881 English Sparrows were imported direct from Europe to various states, the last consignment being sent to Iowa City, Iowa, in 1881. Since that time the birds have spread themselves over nearly the whole of the United States and Canada, and there is little doubt that in a few years they will have possession of the entire country.

The object of the introduction of the English Sparrow was the destruction of insect pests. As destroyers of insects they have proven a lamentable failure in this country. All reports concerning them are alike: to-wit, they do very little good and an immense amount of harm. In a number of states bounties have been offered for their destruction, but as there was no concerted action all over the country the diminution in numbers was scarcely perceptible. The birds destroy fruit and grain, both in the blossom and in the more or less advanced state, and they annoy and drive away large numbers of beneficial birds. The few insects they destroy are but a trifle in the scale when the large number of insectivorous birds driven away by them is considered.

Government analyses of 522 stomachs showed that 22 contained wheat, 327 oats, 71 corn, 57 fruit seed, 102 grass seed, 85 weed seed, 219 vegetable matter, 19 bread, rice, etc., 47 noxious insects, 50 beneficial insects, 31 insects of no economic importance.

The indigenous birds which make war on and destroy the English Sparrow are the Shrike, Purple Grackle, Crow Blackbird, Sparrow Hawk, Screech Owl, Cooper's Hawk and the Sharp-shinned Hawk, but unfortunately some of these also destroy beneficial birds.

The principal interest in the English Sparrow in this country centers in measures for its destruction. Bounty laws have been tried but proved of little avail for obvious reasons, but in a great many places in this country the 
birds have been used for the table or have taken the place of pigeons for trap shooting. There is little doubt that these uses would be more extensive if there were an easy method of trapping the birds, but the English Sparrow is as shrewd as he is worthless. Mr. W. T. Fill has been very successful in trapping the birds for use at the traps and in an exhaustive publication on the English Sparrow issued by the government in $1889 \mathrm{Mr}$. Hill gives a description of his methods of capturing the pests. The article originally appeared in the American Field and the apparatus and methods employed are described as follows:

"If we wish to catch a bird we must first acquaint ourselves with its nature and habits, that we may intelligently bring to bear upon it the proper means to insure success. Many birds, at certain seasons of the year, are readily caught with simple devices carelessly applied, but the English Sparrow, at all times, is the same cumning, wary little fellow, not to be caught with chaff alone, and great care is necessary in any approach upon it. Considering, however, that we have a vantage ground in its gregarious, nomadic halits, and following in this direction, we produce something that appeals directly to its extreme greediness and curiosity, which shall be life-like and real; and, realizing that it is quick to take alarm, we so apply it as to cause the bird to act impulsively, and to enable us to take it by surprise as much as possible.

"The method used so successfully and exclusively by me requires nets, with decoy and braced birds, placed in the line of flight of the birds to and from their sleeping and feeding places. The wild birds are influenced by the decoy birds and then directed into the nets by means of the braced birds, and are invariably caught while on the wing or in the act of settling. The nets can also be used to great advantage in places where the birds are known to harbor, in which case decoy birds are not necessary; but there should be no building, tree or other object for the bird to alight upon inside of fifty yards from the nets, 


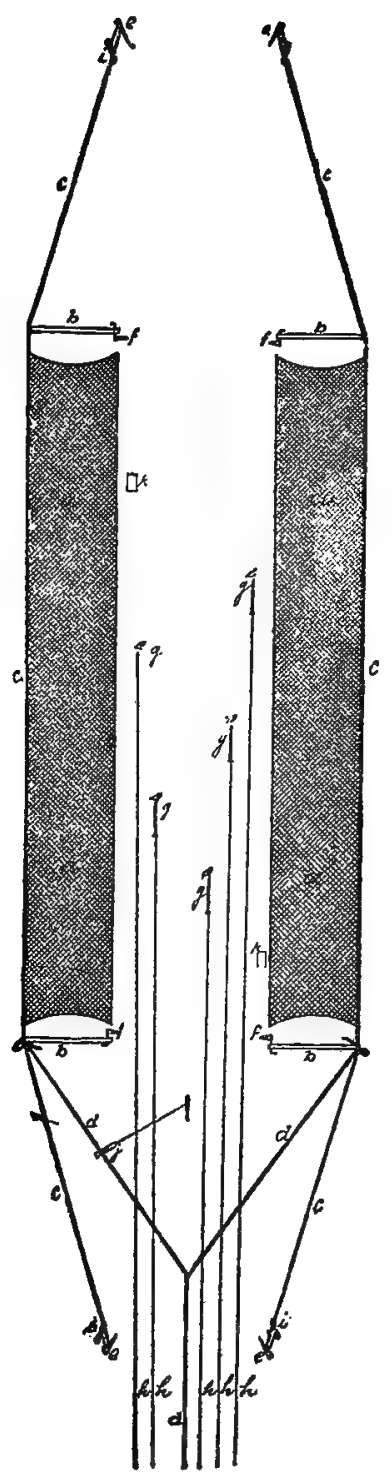

Frg. r.

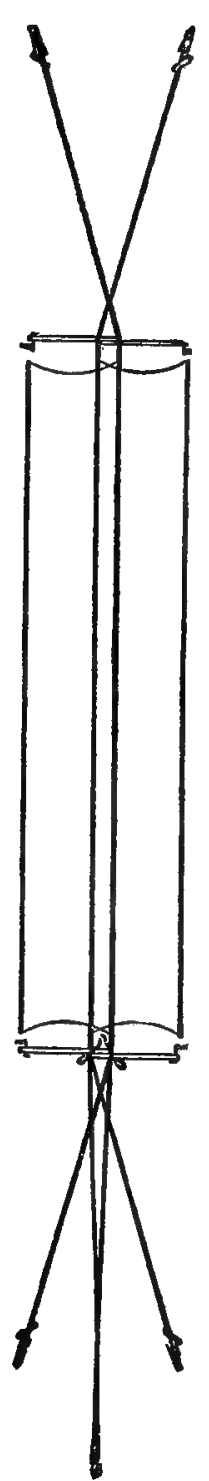

FIG. II. 
it being best to attract its attention while on the wing, as well as to prevent it from discerning anything unusual. The skillful operation of the nets in the main consists in properly judging the flight of the bird in connection with the movements of the nets, and to so control the force of pulling in closing them as to cause the net to strike the bird when the radius of the semi-circle of either wing is at a vertical point. The irregularity of the flight of the Sparrow makes it difficult to catch many at one time.

"The mechanical operation of these nets is shown in Figs. I and II. Fig. I shows nets open, lying flat upon the ground. By pulling (d) each net is caused to move upward and inward to the completion of a half circle, one net slightly overlapping the other when closed, as shown in Fig. II. The four points of each net formed by the two cheeks (f) and two heel-pins (e) are on a straight line. The nets are stretched tight over the tops of staffs (b) which have socket attachment and work on wire in check as a pivot or hinge. The tension on pull-line will keep the nets straight and even, except when a strong wind blows across them, in which case the arm or pullline is shortened or a pully (j) attached.

"The nets should be made of linen material, about the size of No. 3.) gilling-thread, of a dark, dirty-green color, the size of mesh being thirteen-sixteenths of an inch from knot to knot, or fifteen knots to a foot. A convenient and serviceable size of net would be thirty fest long by seven feet deep, to use with four foot staffs. They should be provided with an arming of heavier cord at the top and bottom edges, to which the top line (c, Fig. I.) should be threaded at top, and to form a stout edging to permit of pegging to the ground at bottom.

"The top-line of the net should be a fine linen cord, about one-eighth of an inch thick, provided at ends with a small wooden clamp (i, Fig. I.) similar to those used on tents; and at the place where the net ends on the top line, one or more loops or eyes should be spliced, to admit the 


$$
\|_{1}^{\mu}
$$


button on top of staff, and also to fasten the arms or pullline into.

"The pull-line should be of the same material as topline, with diverging arms at the end next to the net. It should be about forty yards long, which is the average distance to stand from the middle of the net while operating it. A round piece of wood, about four inches long, is temporarily fastened to it to permit of taking a good grip while pulling.

"The staffs should be about four feet long and threequarters of an inch in diameter, of some light, strong wood, with brass socket and eye (a, Fig. III.) at bottom, and button and ridge (b, Fig. III.) also of brass at top.

"The cheeks (a, Fig. IV.) are wedge-shaped stakes averaging nine inches long, with wire (No. 10) driven in about an inch from the top, which at a projection of an inch is bent upwards for about an inch. They should be made of hickory or other hard wood and the wire should fit in the wood so snugly as to barely permit of being moved with the fingers.

"The heel-pins (b, Fig. IV.) should also be made of hard wood, about eighteen inches long, and one inch in diameter at thickest part, tapering to a point, with projection at top to prevent cord from slipping off.

"The crooks (c, Fig IV.) which are used for staking the bottom edge of net to the ground, are cut from the branches of some.hard wood tree, the long end being about six inches in length.

"The bobber (1, Fig. V.), which is used in connection with fly-stick for raising and flying braced bird, is constructed as follows: $-a$ is a piece of hard wood two and a half inches long, half an inch thick, and five-eighths of an inch wide; $b$ is a piece of No. 10 wire that when bent so as to form an eye at the top is nine inches long, and passes through $a$, leaving a space of half an inch between wires, in which the fly stick moves up and down; $c$ is also of No. 10 wire, bent as shown, passing through $a$ hori- 


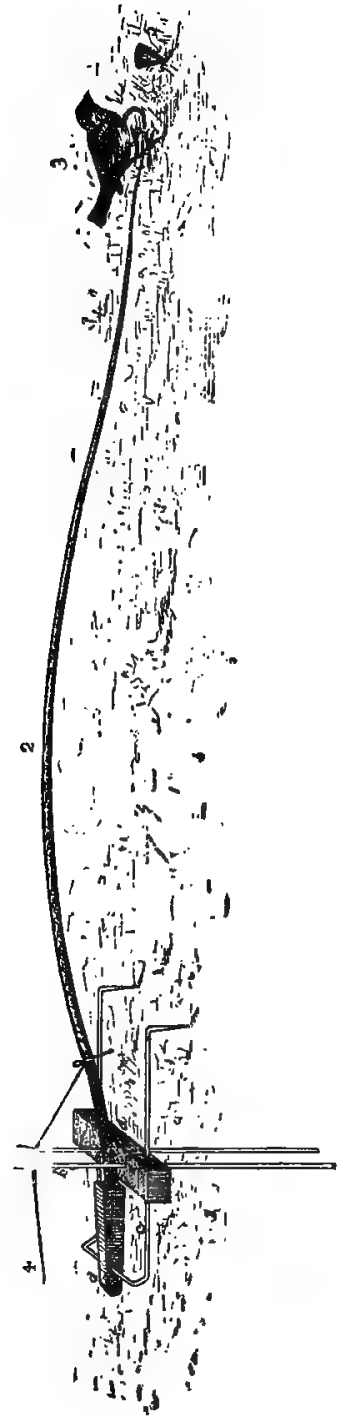

Frg. V.-The above cut represents braced bird, ar,d appliances for using it; 1 bobber. 2 fly-stick, 3 braced bird, 4 brace-line, 5 water-cup.

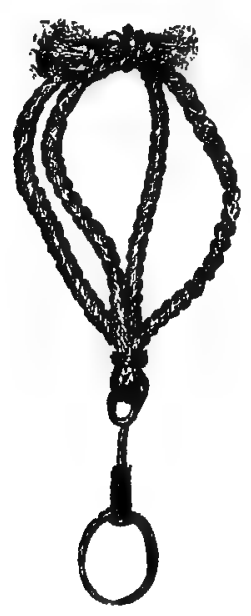

FIG, v1.

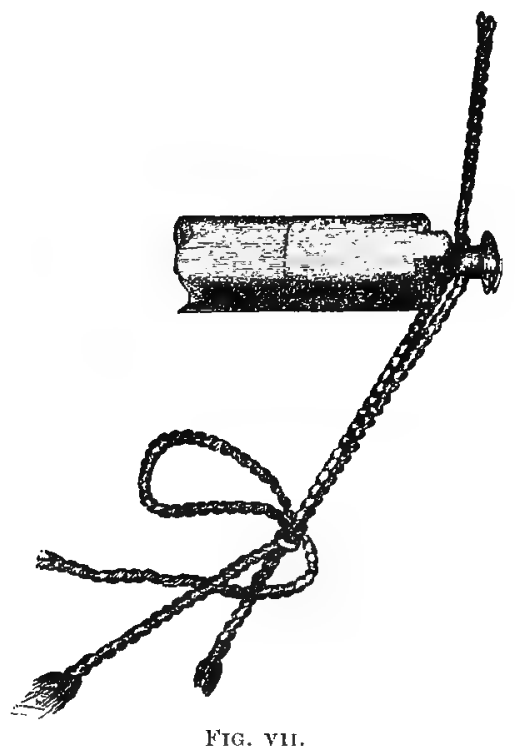

F'IG. VII. 
zontally outside of perpendicular wire $b$; the ends being pointed and bent downwards, are forced into the ground together with the long ends of $b$, which keeps it firmly in position; $d$ is also a piece of wood pivoted on wire $c$, with tapering hole in end, into which the fly-stick is inserted. The wires should fit snugly in $a$, so as to permit only of being moved to suit the conditions of hard and soft ground, and to regulate the height of raising bird; $d$ should work more easily on wire $c$, yet not loosely. To raise fly-stick pass brace-line through eye in top of wire $b$, and fasten to stick.

"The fly-stick (2, Fig. V.), to which the braced bird is attached, and on which it is caused to sit, is a stiff willow switch about two feet long, with loop about four and a half inches long, made of fishing-line, wrapped on the small end by means of waxed thread.

"The brace (Fig. VI.), is composed of four cords and swivel, to be placed on bird as a means of fastening it without injury, and to leave every movement of the bird free and natural. The ring should be of German silver wire, formed over a lead pencil, a common pin completing the swivel. The cord should be of soft cotton, which when stretched in a straight line should measure about one and three-fourths inches. To put it on the bird pass it over its head so as to appear like two cords encircling its body with swivel at the breast-bone, and the knot of cords in the centre of the back, when it will only be necessary to put each wing and leg of the bird (in the order named) between ths cords on each side of the brace.

"The brace-lines should be of mattress wire, fifty yards long, and wound upon reel to prevent twisting.

"Having described each part separately we will now consider how to put them together. Taking for granted that the place which we have selected to put the nets down on is perfectly level and clean, and that the end of the pull line will reach a fence or some slight cover, the 
pack is placed upon the ground in the middle of the place where the nets'are to be set, and the nets are laid in a line on each side of it. We now take two staffs and lapping them about nine inches, lay them on the ground at ends of top lines of nets, nearest where we intend to stand. Taking the hatchet we drive two heel-pins in at the extremes of the staffs, when the distance between the two pins will be the length of both staffs, less the nine inches we lapped them. Having taken each top-line and allowed about a foot of slack by means of clamps, and placed them over heel-pins, taking also an extra turn, we go to the other end and taking with us two more heel-pins repeat what we have just done, taking care that the lines are stretched perfectly straight and tight, and that these pins, upon which so much strain comes, are secure. The top-lines of nets now form two straight, parallel lines, and care should be taken not to move them in any way until after the checks are driven in. These should now be driven in at the points along top-line where the eyes appear at ends of nets, inclining slightly outward so that the wire will project on outside of line sufficiently to cause the net when stretched on staff and held perpendicularly to have a tendency to fall inward. We now pass the socket of stafits over wires in the cheeks, and let out sufficient of the slack of top line to permit of their being stretched over and attached to button on top of staffs. This being done we proceed to stake down the bottom edges of nets-first the four corners, and then the hollow places between them. The bobbers and fly-sticks come next, and if five are used they should be placed as shown in Fig. I., the lines attached, some food for birds placed at ends of fly-sticks. Then we can put on the pull-line, the ends of the arms entering into the same eyes of top-lines the buttons of staffs have. Now we are all ready but the braced birds, which are put on sticks by passing the loop at the end entirely through the ring of brace, then passing bird through loop and pulling tight on ring. We now 
retire to the end of the pull-line and when seated upon camp stool we are ready for business.

"Now this may all appear too extensive and complicated at first for some to attempt, but there are members of every club who have sufficient ingenuity and intuition to construct and use their own nets, which would not only be a gratification of their individual pleasure, but also a source of profit and advantage to the members in general. With these nets, and by following the instructions given, the merest tyro could catch a great many birds in a day-frequently a hundred or more. It should always be borne in mind that the method is not in any way to be considered as a baited trap, but that the principle involved is to take the bird unawares-to fool itand that it is easier to fool one than ten. The number caught at the end of the day will depend largely on bagging every bird that comes within scope of the nets. Make it a rule to be satisfied with one, if no others are in sight, for after the old adage "a bird in the hand" etc., a Sparrow in the nets is worth seventeen on the fence.

"As to when and where to go, while there are some given rules for this, still the birds are so quick to take alarm and so communicative, that it is not possible at times to account for all their movements. Their vast numbers and nomadic habits, however, will offset this, and by a little study of the habits of the birds, and by a few practical lessons in the shape of successes and failures, it will not be difficult to determine where a good catch can be made."

Sparrow, Field.-Length, five and two-thirds inches; extent, eight inches; bill, one-third of an inch, reddish flesh color; above, reddish brown, center of back streaked with black; wing and tail feathers, dark brown, the former edged with reddish brown; the small feathers of the wings are also tipped with white, forming two light bands; rump, grayish brown; below, white, tinged with buff on the breast and sides. 
There is no apparent difference in the plumage of male and female; but the winter dress is much duller and browner than that of spring and summer. The young are spotted with dusky on the breast during their first summer.

The birds nest on the ground or in low bushes, the nest being built of grasses, tendrils and small roots and lined with fine grass and hair. The eggs are from three to five in number, of a white or bluish white thickly spotted with brown.

They breed in the eastern United States and Canada and spend the winter principally south of the Middle States. They are very abundant in New Jersey, arriving here about March 18 and leaving towards the end of October, although a few winter in the southern part of the state.

Their song begins with three clear, plaintive whistles, and ends with a trill becoming more rapid towards the close. It has been likened to Fee-o, fee-o, fee-o, few-fewfew, fee-fee-fee.

The food of the birds consists of seeds, principally of wild plants.

Sparrow, Fox.-Length, seven inches; extent, eleven inches; bill, halt an inch, dusky above and yellow below; chestnut brown above, all the feathers edged slightly with gray; rump, grayish brown; wings and tail, bright tawny, long wing feathers dusky, edged with tawny; below, pure white, throat and breast coarsely spotted with tawny, sides of the body streaked with tawny and dark brown.

The birds nest on the ground or in low trees and bushes. The nest is built of coarse grasses and lined with finer grasses, hair, moss and feathers. The eggs are either four or five in number, pale bluish, spotted with brown, and four-fifths by two-thirds of an inch in size.

The birds breed north of the Gulf of St. Lawrence and 
most of them spend the winter" in the Southern States northward as far as the Middle States. They are numerous in New Jersey from March 10 to April 10 and again from October 15 to December 1, some wintering in the southern part of the state.

Their note call is a $z i p$, but their song, not frequently heard in New Jersey, is a sweet warble of full cadence.

The food of these birds consists of grass seeds and the larvae of insects.

\section{Sparrow, Grasshopper, or Yellow-winged Spar-} row.-Length, five and a third inches; extent, eight inches; bill, two-fifths of an inch, short and stout, dark above and pale below; crown, hlack, feathers narrowly edged with gray; a buff central stripe reaching back to the neck; upper surface of the body, speckled with black, chestnut and gray; wings and tail, dull brown, edged with buff; below, white, strongly suffused with buff on the breast and sides; bend of the wing and spot before the eye, bright yellow; legs and feet, flesh color. The young bird is dusky above, all the feathers bordered with buff; below, white, with dusky spots on the breast and sides.

The birds nest on the ground, the nest being built of grasses, sometimes lined with hair. The eggs are from four to five in number, white, with reddish brown spots, and three-fourths by one-half inch in size.

The birds breed throughout the eastern United States and spend the winter in the West Indies and Mexico. They are most numerous in the dry uplands. They arrive in New Jersey about the first of May and leave about October 20.

Their song is a very weak and insectlike chirrup, somewhat resembling the grasshopper's; although it may be heard at a distance of over a hundred feet the chances are that a person not listening for it would pass a singing bird by within ten feet without noticing it. 


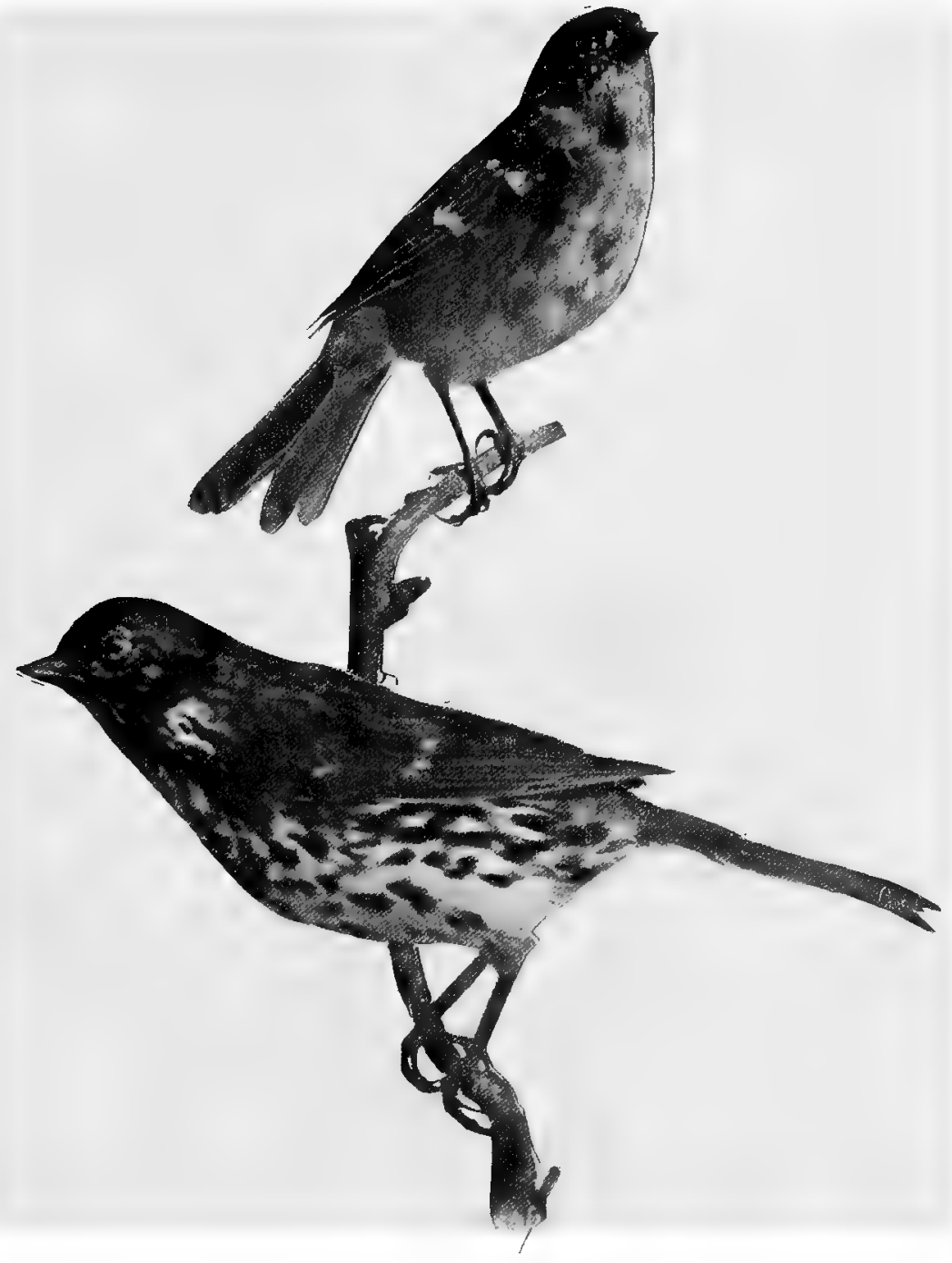

FOX SPARROW TREF SPARROW. 
.

$$
\text { . }
$$


The food of the birds consists of grass seeds and the larvae of insects.

Sparrow, Menslow's.-Length, five inches; extent, seven inches; bill, two-fifths of an inch; head, top and sides, olive green; sides of crown, black; back and wings, chestnut brown, the feathers with black streaks and gray edges; below, white, breast and sides tinged with buff and spotted with black; tail, brown and gray; long wing feathers, dull brown; bend of wing, yellow.

The birds nest on the ground, the nest being built of grasses, sometimes lined with hair. The eggs are either four or five in number, of a soiled white, with brown spots, and three-fourths by three-fifths of an inch in size.

The birds breed in the eastern United States as far northward as central New Jersey, but are rather rare in this state, occurring mainly in cranberry bogs near the coast.

Their song is a tre-wick, ssrrt, ssrrt.

Their food consists of seeds of grasses and the larvae of insects.

Sparrow, Ipswich.-Length, six and a quarter inches; extent, nine inches; bill, two-fifths of an inch, brown; head and back, light brownish gray, streaked with brown, a spot of yellow before the eye and a white line over the eye; breast and belly, white, streaked with brown; tail, grayish brown, the feathers margined with light gray, long wing feathers, brown, edged with gray and with a spot of yellow at the bend; feet, brown. The nest is a mere depression in the ground; the eggs are four or five in number, pale green, with brown spots. The bird breeds in Nova Scotia and spends the winter southward as far as Virginia. It is occasionally found along the sand dunes of the New Jersey coast. Its song is weak and halting and generally confined to a sharp chirp. 
Sparrow, Lincoln's.-Length, five and three-fourths inches; bill, two-fifths of an inch. General appearance similar to the Song Sparrow. The upper parts consist of black, gray and brown streaks, the under parts are white with black streaks and with strong buff tint across the breast and down the sides, a stripe of yellow buff on each side of the head from the base of the bill. They nest on the ground, the nest being made of grasses, small roots and tendrils and lined with hair. The eggs are four or five in number, white, with a green or yellow tinge, and four-fifths by three-fifths of an inch in size. They breed north of the United States and southward along the high mountaius and spend thewinter in Mexico. They are very rare in New Jersey and never seen excepting during the spring or fall migrations.

Sparrow, Seasiale.-Length, six inches; bill, threefifths of an inch, lead color; throat, white, a dusky line on each side; a yellow line before the eye; back, grayish green; breast, mottled gray and white; belly, white; sides, gray; tail, grayish brown, the feathers having dull greenish edges; wings, dusky, with yellow line at the bend; feet, dark. Young birds are very different; brown above, streaked with black; buffy white below, with black streaks on the breast.

The birds nest on the ground, the nest being built of grasses and reeds and lined with finer grasses. The eggs are either three or four in number, white, with a bluish tinge, and with brown spots most numerous near the large end, and four-fifths by two-thirds of an inch in size.

The birds breed from Massachusetts southward along the Atlantic coast and in the winter go southward of North Carolina. They are very abundant along the New Jersey coast and Delaware bay, in the brackish marshes, a few occasionally wintering in the southern part of the state.

Their song consists of a chirp of four or five notes. 
The food consists principally of insects and larvae picked up along the sands.

Sparrow, song.-Length, six and a half inches; extent, eight and a half inches; bill, half an inch, horn color; crown, brown, with gray line down the centre, a gray line over the eye and brown line behind the eye; back, brown, with bay, gray and black streaks; breast, white, streaked with chestnut and black, the spots coalescing in the middle and forming a more or less distinct spot; belly, white; sides, white, with long pointed dark chestnut and black spots; tail, dark brown, edged with lighter brown; wings, dark brown, edged with bay; legs, flesh color.

The birds nest on the ground or in bushes, the nest being built of grasses, roots, leaves and bark, lined with fine grasses and sometimes with hair. When undisturbed the birds bring out three broods in a season. The eggs are four or five in number, of a white or a bluish white, with numerous brown spots and blotches, differing in intensity of color in different nests, and three-fourths by threefifths of an inch in size.

The birds breed in the Eastern United States north of the Southern States and are generally distributed. In New Jersey they are the most numerous of all the Sparrows; they prefer the vicinity of water and in the winter large numbers of them betake themselves to the swamps and meadows along the Delaware.

The song, which is heard day and night for twelve months in the year, more sparingly in the winter months, somewhat resembles the beginning of a Canary's song, but it is different whether uttered on the wing or in the bush. Thoreau compares it to Olit, olit, olit-chip, chip, chip, che-rhar-che-wiss, wiss, and again to Maids, maids, maids, hang on your teakettle-ettle-ettle.

The food of the birds consists principally of seeds of grass and the larvae of insects. 
Sparrow, Savamma.-Length, five and two-thirds inches; bill, two-fifths of an inch, dark above, pale below; very rnuch like the Song Sparrow in general coloration, but has a yellow spot before the eye and on the bend of the wing; the black streaking above is more pronounced and the head is streaked with buff instead of chestnut; in the edging of the tail the reddish brown is also replaced by buff; feet, light flesh color.

The birds nest on the ground, the nest being built of grass lined with finer grasses or hair. The eggs are four or five in number, bluish white with brown spots and sometimes with a brown tint all over, and three-fourths by three-fifths of an inch in size.

The birds breed in the northern Middle States and northward and spend the winter in southern New Jersey and southward. In New Jersey they are numerous during migrations, especially along the coast and rivers, between March 20 and May 15, and again between September 1 and October 20; many winter in the southern part of the state and some breed in the northern part.

Their song is a weak, musical trill, generally heard in the evening, described by Samuels as chewee chewittchewitt-chewitt-chewe-et-chewee.

Their food consists of seeds and the larvae of insects.

Sparrow, Sharp-tailed.-Length, five and threefifths inches; bill, half an inch, extremely sharp; throat, white, an orange line from over the eye down the side of the throat, meeting another from the base of the bill; crown, brown, with a gray line through the centre; back, olive brown, with buff and black streaks; breast, white, with buff tinge and streaked with black; belly, white; sides, light buff, streaked with black; tail, each feather sharply pointed and the outer ones much shorter than those in the middle, gray and olive; wing, brown, yellow at the bend; feet, clay color. Young birds quite buff below and black and buff above. 
The nests of these birds are firmly fastened between tussocks in swamps and marshes and there are two broods each season. The eggs are either three or four in number, of a white or soiled white with fine brown spots, most numerous near the large end, and four-fifths by three-fifths of an inch in size.

The birds breed along the Atlantic coast from Maine to North Carolina and in the winter are distributed along the coast of the South Atlantic States. In New Jersey they are very abundant in the salt water marshes and along the Delaware.

Their song is short, gasping and husky, described by Dr. Dwight as lic-se-e-e-oop.

They feed on sea food with scraps of shellfish and drift.

Two other Sharp-tailed Sparrows occur in the United States: the Acadian Sharptail, replacing the present bird on the coasts of New Brunswick and Nova Scotia, and the other, Nelson's Sharptail, of the fresh water marshes of the upper Mississippi valley. Both occur in New Jersey during migrations. They closely resemble the common Sharptail but are rather smaller. The Acadian is duller all over, with olive tints below and with no light streaks above, while the Nelson's is brighter colored; the breast bright buff, with scarcely any spots, and the light streaks above very bright and nearly pure white.

Sparrow, Swamp.-Length, five and three-fourths inches; extent, eight inches; bill, half an inch long, dusky above and bluish below; crown, bay, in young birds and in winter streaked with black and gray; forehead, black; throat, white; a gray line over the eye and a black line behind the eye; back, black, skirted with bay; breast, light ash, in winter suffused with a brownish tint; middle of belly, white; rump, grayish brown, sometimes streaked with black; sides, pale grayish brown; tail, grayish brown; wings, brown, with black spots, long feathers 
edged with bay;legs, brown. The young are spotted with dusky below.

The nest is built on the ground or in a tussock in swamps, of coarse grasses, roots, leaves and bark, lined with finer grasses and sometimes with hair. The eggs are four or five in number, of a white or a bluish white color, with brown spots and frequently brown blotches, and three-fourths by three-fifths of an inch in size.

The birds breed in the Eastern United States from the Middle States northward and winter from the southern border of the Middle States southward. Some breed and some winter in New Jersey but they are more plentiful here during the spring and fall migrations.

Their song is a lisping tweet-tweet-tweet, very short.

Their food consists of grass seeds, wild oats and insects.

Sparrow, Tree, or Winter Chippy. - Length, six and one-third inches; extent, nine and a half inches; bill, two-fifths of an inch, black, except the lower part of the base, which is yellow; head, a bright bay, sometimes with gray edgings, a gray line over the eye and a bay line behind it; back, dark brown, with streaks of bay, black and light buff; breast, grayish white, with faint black and bay spot in the centre; middle of belly, white; rump, grayish brown; sides, grayish brown, lighter than rump; tail, forked, black, with outside edge buffy white; wings, dark brown, tipped with white, forming two bands across the middle; legs, brownish clay; feet, brownish black.

The birds nest on or near the ground, the nest being built of grasses, roots and hair. The eggs are either four or five in number, of a pale green or a greenish blue with brown spots, and three-fourths by three-fifths of an inch in size.

The birds breed in the far north and in winter are distributed throughout the eastern United States; in New 
Jersey they are very plentiful, frequently in large flocks, between October 15 and April 15.

Their song, heard generally in February and 'March, is like that of a Canary, but finer and not so loud; Burroughs says that it is "a soft, sweet note, almost running into a warble."

The food of the birds consists of seeds of weeds and grasses.

\section{Sparrow, Wesper, Grass Finch, or Bay-winged} Bunting.-Length, five and three-quarter inches; extent, ten and a half inches. The upper parts are an ashy brown, mottled with deep brown or black; wings, dusky, edged with brown and with white tips to small feathers; outer feather on tail, white on outside edge and tipped with white, the next tipped and edged for half an inch with the same, the rest dusky, edged with pale brown; bill, two-fifths of an inch in length, dark brown above, paler below; around the eye is a narrow circle of white; the upper part of the breast is buffy white, thickly streaked with pointed spots of black that pass along the sides; belly, white; legs and feet, flesh-colored.

The nest is built on the ground of coarse grasses, lined with finer grasses and long hairs. The eggs are either four or five in number, of a bluish white or a grayish white, spotted with brown, and four-fifths by three-fifths of an inch in size.

The birds breed from Virginia to Nova Scotia, passing the winter in the southern part of New Jersey and southward; migrants arrive about the middle of April and return about the first of November.

The song, generally heard early in the morning and again towards evening, is loud, clear and ringing, compared by Mabel Osgood Wright to chewee-chewee-chewee, tira-lira-lira-lee.

The food of the bird consists of seeds with some berries and insects. 
Sparrow, w'hite-Crowned.-Length, six and three quarter inches; bill, half an inch, dusky above, flesh color below; crown, jet black, with a broad central white stripe and a narrow one over each eye; back, mottled brown and gray; rump, grayish brown; tail and wing, dull brown, the latter crossed by two white bars; below, gray; center of belly and throat, white. Young birds have the head brown above. A rare migrant in New Jersey, breeding north of the United States, with much the same habits as the following.

Sparrow, White-thronted, or Peabody Bird. -Length, six and three-quarter inches; extent, nine inches; bill, half an inch in length, bluish horn color; head, a yellow line before the eye, centre of crown a white stripe and on each side of this a much wider black stripe; white stripe from the eye backwirds alon rside of head and a white patch on the throat; back, brown with black streaks and a light edge of gray; breast, ash; belly, white; rump, grayish brown; sides, grayish brown; tail and wings, grayish brown, the latter yellow at the bend and crossed by two bars of white; legs, flesh-color. The young bird has the head brown instead of black and white, and the white throat is more obscured.

The nests are built on the ground or in low bushes, of grasses, roots, moss and bark, lined with finer grass: The eggs are either four or five in number, of a bluish white with brown spots, and four-fifths by three-fifths of an inch in size.

The birds breed along the northern border of the United States northward and along the high mountains southward and in the winter are distributed throughout the eastern United States from about the middle of New Jersey southward.

Their song, which is plaintive, remarkably sweet and clear, is heard all winter.

Their food consists of seeds, principally those of alders and weeds. 
Sparrow, Yellow-winged. See Grasshopper Sparrow.

Spirit Duck. See Buffle-head Duck.

Sprigtail. See Pintail Duck.

stake Driver. See Bittern.

Summer Duck. See Wood Duck.

Summer Yellowbird. See Yellow Warbler.

Swallow, Bank, or Sind Martin.-Length, five and a half inches; extent, ten inches; bill, one fifth of an inch, black; plumage above generally sooty brown; throat, white; breast with brownish gray band; belly and sides, white; tail, forked, brown, the exterior feathers slightly edged with gray; wings, brown, the wings and tail being darker than the lack; feet, dark.

The birds nest in colonies in clay or sandy banks; making holes or tunnels from twelve to eighteen inches in length, at the extremity of which is the nest, made of grass and feathers. The' eggs are from four to six in number, white, and two-thirds by one-half inch in size. There are two broods each season.

The birds breed throughout the whole of North America and spend the winter in the West Indies, Central America and southwards. Some remain all summer to breed in New Jersey, but they are more plentiful here during migrations, from August 15 to September 1 and again from April 8 to 20 .

Their song is a gladsome twitter.

Their food consists of insects, generally taken on the wing.

Swallow, Harm.-Length, seven inches; extent, thirteen inches; bill, one fourth of an inch, black; throat, 
dark chestnut red; back, steel-blue; breast and belly, lighter chestnut; tail, forked, the outer feathers an inch and a quarter longer than the next pair; color of tail, brownish black, with white spots on exterior feathers, and reflections of green; wings, above black with reflections of green; legs, dark brown. The young birds are lighter below, duller above, and with the outer tail feathers only three-eighths of an inch longer than the next pair.

The birds nest in barns or any convenient building, the nest being made of mud and grass and lined with finer grass and feathers. The eggs are from four to six in number, white, with brown spots, and three-fourths by one-half inch in size.

The birds breed throughout the whole of North America and spend the winter in Mexico and southward. They are very abundant in New Jersey from April 19 to September 1.

Their song is a pleasant twitter.

Their food consists of insects generally taken on the wing near the ground.

Swallow, Chimmey. See Chimney Swift.

Swallow, Cliff, or Eave Swallow.-Length, five and a half to six inches; extent, ten to eleven inches; bill, one-fifth of an inch long, black; forehead, buff, forming a crescent-shaped frontlet; crown, steel-blue; throat and sides of head, chestnut, the former with a steel blue central spot, a brownish gray band around the hind neck; back, steel-blue, with indistinct white streaks; breast, brownish gray; belly, white; tail, nearly square, dark brown, with greenish lustre; rump, chestnut; wings, dark brown, glossed with greenish; feet, brown.

The location of the nest depends a great deal on circumstances. When near human habitations the birds build their nests under the eaves of houses or other buildings; in uninhabited parts they nest under cliffs; when the 
1 

nests are found under eaves they are of a gourd-shape with the opening near the neck. The nests are very fragile, made of mud with a little straw and lined with feathers. The birds breed in colonies and raise two broods a year. The eggs are either four or five in number, white with brown spots, and four-fifths by one-half inch in size.

They breed throughout the whole of North America and spend the winter in Mexico and Central America. They are regular but not very abundant in New Jersey, principally along the coast and in river valleys, some breeding and summering in the southern part of the state, but most abundant during migrations; those that spend the summer in the state arrive about the first of May and leave about the first of September.

Their cry is nearer a squeak than a twitter.

They feed on insects, taken on the wing and destroy a great many flies.

Swallow, Eave. See Cliff Swallow.

, swallow, Rough-winged.-This bird very much resembles in appearance and habits the Bank Swallow. It is a trifle larger and it does not always nest in banks, but frequently under bridges, railroad trestles and in stone walls. The principal difference between the two is that the Rough-winged is ashy on the under surface, shading gradually to white on the middle of the belly; with no white throat and sharply defined breast band which characterize the Bank Swallow. The old birds have the tips of the outer webs of the outermost wing feather bent backwards and stiffened, forming a series of little hooks, which are very perceptible if the finger is rubbed along the outer edge of the feather towards the tip. Its eggs number from four to eight, are white in color, and three-fourths by one-half an inch in size. They breed from Connecticut and New Jersey southward, arriving 
about April 25 and leaving about September 1, spending the winter in Mexico and the south.

Swallow, Sea. See Common Tern.

\section{Swallow, Tree, or W\%ite-bellied Swallow.-} The upper parts all steel blue, greenish in the autumn; the under parts pure white. The length of the birds is six inches. The young are sooty brown above, with no metallic reflections. Some breed in bird boxes when convenient, but many still prefer a hollow tree or an abandoned Woodpecker hole, disdaining the commodities of civilization. The nest is made of grass and feathers. The eggs are from four to seven in number, generally six, white, three-fourths by one-half inch in size. The birds breed in the Middle States and northward, being found in spring and summer along the New Jersey coast and in the pine barrens. They spend the winter in Florida and the West Indies southward to Central America. Migrants arrive in New Jersey between April 20 and May 15 and again between August 15 and September 1. Their song is a warbling twitter. Their food consists principally of insects, taken on the wing, but during migrations they also feed on bayberries.

\section{Swallow, White-bellied. Seè Tree Swallow.}

Swan, Whistling.-This bird is of rare occurrence in New Jersey, a specimen being occasionally seen along the coast in winter. It is fifty-five inches in length and the entire plumage is white; the bill and feet are black. It builds its nest on the ground in high northern latitudes and in the winter is of frequent occurrence along the coast of the south Atlantic States.

Swift, Chimmey.--Length, four and a half inches; extent, twelve inches. The plumage is of a sooty brown, except the chin and line over the eye, which are of a dull 
white: the bill is only one-seventh of an inch in length, hard and black; legs, dull black; thighs, naked and of the same tint; claws, very sharp; the wings when closed extend an inch and a half beyond the tip of the tail, which is rounded and consists of ten feathers, the shafts of which are produced, forming sharp spines.

In wild regions the nest is built in a hollow tree, but wherever there are any settlements, in a chimney. It is a basket-like contrivance, made of dead twigs suapped from trees and glued together with the saliva of the bird and similarly fastened to the side of the chimney. The eggs are from four to six in number, white, and four-fifths by one-half inch in size.

The birds breed and are distributed from Virginia to Canada, coming to New Jersey about the middle of April and leaving for the Southern States shortly after the first of October.

Its song is a rolling twitter.

The food consists of insects, invariably caught on the wing. The birds feed more frequently in the late afternoon and early evening.

Tanager, scarlet.-Length, seven and one-fourth inches; extent, twelve inches; bill, half an inch. The plumage of the male is a bright scarlet, excepting the wings and tail, which are a jet black, and the under part of the wing, which is white. In the female the upper parts are an olive green, the wings and tail a dark slate, indistinctly edged with green, and the under parts yellow olive. The feet are of a deep horn color. In autumn and winter the male assumes a dress exactly like that of the female, except that the wings are blacker. The red dress is again acquired in early spring or late winter.

The nest is flat and apparently carelessly built and generally found near the end of a limb of a pine or oak, the birds very seldom leaving the woods for the purpose of breeding. The nest is made of twigs and stalks and lined 
with tendrils and finer vegetation. The eggs are three or four in number, greenish blue, with brownish spots, and nine-tenths by two-thirds of an inch in size.

The birds breed in the Eastern United States northward from New Jersey and spend the winter in the $\mathrm{W}^{\top}$ est Indies and Mexico and southward. Migrants pass through from May 5 to 18 and from September 10 to October 10.

The song is rather harsh, not very melodious and still not unpleasant when heard in the woods.

Their food consists of fruits and berries, but they also take large numbers of beetles, larvae of insects, wasps, hornets, bumble bees and other large-winged insects.

Teal, Hune-winged.-Length, sixteen inches; extent, twenty-five inches; bill, one and three-fifths inches, dark slate; head, dark gray, with purplish reflections; crown, blackish; chin, black; white vertical band on each side of the head in front of the eye; back, dark slate, the feathers with buff edgings; breast, belly and sides, light brown, tinged with cinnamon and with dusky spots and mottling; tail, dark brown, pointed, reaching two inches beyond the closed wings; wings, slaty, with a grayish blue band and a bright green spot, between which the feathers are tipped with white; legs and feet, yellow. In the female the crown is slate, with an indistinct edge of gray, the sides of the heal and the neck are light brown with black spots and the green spot on the wings is a darker hue. The number of eggs is from six to twelve, of a cream color, one and nine-tenths by one and three-tenths inches in size. They breed throughout the whole of northern North America and are found mainly on fresh water, being most plentiful in New Jersey in September and April. They spend the winter in the south as far down as the West Indies and northern South America. Their food is principally vegetable, the seeds of reeds and 
wild oats, although they also take insects and tarpoles. Their flesh is delicate and highly esteerned for the table.

Teal, Green-winged.-Length, fourteen and a half inches; extent, twenty-four iuches; bill, one and onethird inches, black; head, bay; sides of head, green; chin, black; upper back, barred fine with lines of black and white; lower back, dark slate; breast, light brown with black spots; belly, white; sides, with white and black lines; tail, brown; wings, slaty, a white bar near the bend and spot of purplish black and rich green on the middle preceded by a rusty bar; feet, gray. The female has the top of the head dark slate with brown edges; the throat and sides of the neck white with black spots and the back dark slate edged with gray. The eggs are from six to twelve in number, cream colored, and one and four-fifths by one and one-fourth inches in size. The birds breed throughout the northern United States and spend the winter south as far down as Cuba. They are more plentiful than the preceding, especially in the spring and fall migrations, rare on the coast and more numerous in large rivers. Their food and flesh are similar to those of the preceding.

Teeter. See Spotted Sandpiper.

Term, Rlack.-Length, ten inches; extent, twentytwo inches; bill, one inch. In summer the back, wings and tail are a slate color and the rest of the plumage black; in the winter the under parts and forehead are white and the back, wings and tail a light gray. The nest is a closely woven and compact contrivance, made of reeds and grasses in the marshes. The eggs are two or three in number, of a light brown with darker brown markings and one and one-third by one inch in size. They breed through the northern interior of temperate North America and spend the winter in the Gulf and South Atlantic States. They occur in New Jersey only 
during the fall migrations. Their food consists principally of dragon flies and aquatic insects.

\section{Tern, Common, W'ilson's Tern, or Sea Swallow.}

-Length, fifteen inches; extent, thirty inches; bill, one and two-fifths inches long, straight, sharp-pointed, crimson-red at the base and black at the end; top of head, black; throat, white; back, gray; breast and belly, pale gray; tail, pale lead, edged on the sides with gray, forked; wings, gray, with silvery white edgings; legs and feet, orange red. In winter the front part of the head and the under parts are white.

There is no pretense whatever of building a nest, the eggs being deposited in dry drift grass where the female covers them during the night and in stormy weather, the rest of the hatching being done by the sun. The eggs are three or four in number, of an olive brown, with brown and purple spots, and one and three-fifths by one and four-fifths inches in size.

The birds breed along the Atlantic coast as far north as Canada and spend the winter in the South Atlantic states along the coast: They were formerly very abundant in New Jersey and their history here is an ableanswer to the argument of persons who claim that the killing of birds does no harm. Years ago the coast of New Jersey was a favorite breeding ground for these birds until the edicts of fashion in millinery demànded their feathers; by 1883 they had been almost exterminated and no nests were found; then a stringent law was passed prohibiting their killing and now they are again beginning to breed in this state; they are quite numerous during migrations, due undoubtedly to prohibitory legislation against their slaughter passed in other states.

Their food consists of fish.

Tern, Forster's. - This bird very much resembles the common Tern, being about the same size; the principal 
difference is that in Forster's Tern the outer web of the tail feathers is lighter than the inner and that the breast and belly are pure white; the eggs of Foster's Tern are a little larger. It breeds in temperate North America, principally on large inland waters, and spends its winters in South America. It is a rare migrant in New Jersey.

Tern, Gull-billed, or aMarsh Tern.-Length, fourteen and a half inches; extent, thirty-four inches; bill, one and two-fifths inches, black and heavy; top of head, black; back, light silver gray; breast and belly, white; tail, forked, white; wings, pale gray with silvery edge; feet, black. In winter the top of the head is white. The eggs are deposited in dry drift grass, from three to five in number, cream with brown spots, and one and four-fifths by one and one-fourth inches in size. The birds breed from Brazil to Long Island and previous to their slaughter for millinery purposes were plentiful along the New Jersey coast, where they are rare now. They spend the winter in southern Mexico and southward. They do not depend on fish for food but take large numbers of insects, capturing them on the wing.

Tern, Least.-Length, nine inches; extent, twenty inches; bill, one and one-tenth inches, yellow, tipped with black; forehead, white; back and tail, light gray; breast and belly, white; wings, gray, with slaty black edges to the outer feathers; feet, orange. In the winter the top of the head is white, spotted with black and the bill is dusky. They breed on sandy beaches, the eggs being three or four in number, cream with brown spots, and one and one-fourth by nine tenths inches in size. They breed from the South Atlantic coast to Massachusetts and spend the winter along the Gulf coast and the coast" of Mexico. They were formerly very numerous in 'New Jersey but now no longer breed here and are seen only during migrations. They were practically exterminated in 
1883, when the breeding birds were killed off for millinery purposes, leaving the young to starve to death. Like the preceeding they vary a fish food with insects of all kinds.

Tern, MTarsh. See Gull-billed Tern.

Tern, Wilson's. See Common Tern.

Thistle-bird. See Goldfinch.

Thrush, Allice's. See Gray-Cheeked Thrush.

Thrush, Blackbird. See Rusty Blackbird.

Thrush, Browm. See Browu Thrasher.

Thrush, Golden-crowned. See Ovenbird.

Thrush, Gray-cheeked.-Length, seven and a half inches; bill, one-half inch in length, slender. Above, brownish olive, nearly uniform, though tail and wings are a trifle brighter; below, white, shading into a light buff on the breast; breast and fore part of the abdomen spotted with olive brown; sides of the head, whitish with whitish streaks on the ear coverts and white spot before the eye; legs, light flesh color. The birds breed in low bushes and shrubs, making a nest of grasses, leaves, bark and lining it with finer grasses. The eggs are four in number, greenish blue with brown spots, and one inch by three-fourths in size. It breeds north of the Uniled . States and spends the winter in Mexico and the south. In New Jersey it is transient, not very numerous, occurring about the middle of May and again between Septem. ber 20 and October 10. Torrey gives its song as wee-o, wee-o, tit-li wee-o. It feeds on berries and insects.

Thrush, Mermit.-Length, seven and one-fifth inches; extent, eleven inches; bill, half an inch long, black above, 
gray below; above, brown, tinged with olive; tail, bright rufous or chestnut; below as in the preceding species.

The nest is built on the ground, of moss, leaves and grass and lined with tendrils and pine needles. The eggs are either three or four in number, of a greenish blue, with brown spots, more numerous near the large end, and six-sevenths by one-third of an inch in size.

It breeds in the northern United States northward and southward along the Alleghany mountains and spends the winter in the lower Middle and Gulf States. In the southern part of New Jersey it is a regular though not numerous winter resident.

Its song is flute-like, very sweet and melodious, but not very loud. Burroughs compares it to $O$ spheral, spheral, O holy, holy, O, clear away, clear up, clear up, and the same author says: "If we take the quality of melody as a test, the Wood Thrush, the Hermit Thrush and the Veery Thrush stand at the head of our list of songsters."

The food of the bird consists of wild berries.

\section{Thrush, Olive-backed, or Swainson's Thrush.-}

Exactly like the Gray-cheeked Thrush in its markings, but distinguished by the brighter buff of the breast, and by a bright buff suffusion on the sides of the head, covering all the marks which are whitish in the Gray-cheeked; feet, pale brown. It nests in bushes and small trees, the nest being built of grasses, moss and bark, lined with finer grasses and tendrils. The eggs are three or four in number, of a greenish blue with brown spots, and ninetenths by two-thirds of an inch in size. It breeds north of the United States, excepting along the higher mountains and spends the winter in the Gulf States and southward. In New Jersey it is fairly abundant during migrations, from May 5 to May 25 and again from Septem. ber 15 to October 15. Its song is like that of the Wood 
Thrush, but not so lively and more melancholy. Its food consists of insects and berries.

Thrush, Swainson's. See Olive-backed Thrush.

Thrush, W'ilson's, or Veery.-Length, seven and a half inches; bill, half an inch; above, uniform tawny brown; below, white; breast and sides of throat, pale buff; faintly spotted with brown. This bird is distinguished from all the other Thrushes by the paleness of the spots on the breast and the fact that they do not extend back on the fore part of the belly; feet, light.

The nest is built on or near the ground, of sticks, bark, twigs, roots and leaves and lined with leaves, small roots and tendrils. The eggs are from three to five in number, of a greenish blue, and five-sixths by one-third of an inch in size.

The birds breed from the middle of New Jersey northward and spend the winter in Mexico and the south. They breed and spend the summer in Northern New Jersey; migrants pass through from May 5 to May 25 and again from September 1 to September 20.

Their song is considered one of the finest heard and is compared by Professor Ridgway to taweel-ah-taweel-ah, twil-ah, twil-ah.

Their food consists of insects and berries.

Thrush, Wood.-Length, one and one-third inches; bill, three-fifths of an inch, dark brown; tawny brown above, becoming very bright on the head and shading into olive brown on the tail; below, pure white, with round black spots extending back to the flanks; ear coverts, streaked black and white.

The nest is built on saplings in low trees and bushes and is compactly woven of leaves, roots, sticks and tendrils, lined with mud and this lined with fine roots. The eggs are from three to five in number, greenish blue in color, and one inch by three-fourths of an inch in size. 


$$
4
$$


1 $i=$ , $\vdots$ 
The birds breed in the eastern United States, as far north as Massachusetts, and spend the winter in Cuba and southward. They are not very plentiful in New Jersey, where they arrive about the first of May and leave about the first of October.

Mabel Osgood Wright, in "Birdcraft," Macmillan \& Co., says of the Wood Thrush: "He is an exquisite vocalist, the tones having a rare quality of rolling vibrance, and, often as he utters his plaintive notes, each one full and deliberate, the song seems like the music of a flute and an aeolian harp strung in the trees. Uoli, he begins and after pausing continues, aeolee, (the last syllable having the harp quality), uoli-uoli-aeolee-lee. First softly, then modulating, reiterating sometimes for an hour together; but compassing in these few syllables the whole range of pure emotion."

The food of these birds consists of insects and berries.

Tilt-up. See Spotted Sandpiper.

Tinker. See Razor-billed Auk.

Titlark, or Pipit.-Length, six and one-third inches; bill, half an inch, dark; white or buff line over eye; back, brownish gray; breast and sides, buff or buffy white, streaked with dark slate on the sides of the throat and across the breast; tail, brownish gray, the outer feather with the terminal half white and the next slightly tipped with white; wings, dark brown, with a somewhat lighter band across the middle; feet, brown.

The nest is built on the ground and is composed of grasses. The eggs are from four to six in number, of a dull white thickly speckled with brown, and four-fifths by three-fifths of an inch in size.

The birds breed in the far north and in the winter go south as far as the southern United States. They are very abundant, generally in flocks in New Jersey, from 
the first of November to the middle of March, especially near the coast.

Their cry is a weak dee-dee when flushed or when on the wing.

Their food consists of insects and the larvae of insects.

Titmouse, Tufted, or Crested Tit.-Length, six inches; extent, seven and a half inches; bill, half an inch long, black; a sharply-pointed and high crest on the head. The color of the plumage on the upper parts is blue gray, the tail and tips of the wings being darker; the under parts are white, tinged with ashy, the sides washed with rusty brown; feet, lead-colored.

The nests are built in hollow stumps, abandoned Woodpecker holes and occasionally in bird boxes, and are made of leaves, moss and bark and lined with feathers and hair. The eggs are from five to eight in number, cream colored with brown spots, and seven-tenths by one-half an inch in size.

The birds breed aud are distributed from the middle of New Jersey southward and are very numerous in the southern part of this state.

Mr. Nehrling compares their song to hee-dle-dee-dle-deedle-dee, and at other times peto-peto-peto-daytee-daytee.

Their food consists of the larvae of insects.

Towhee. See Chewink.

Torchbird. See Blackburnian Warbler.

Traimp. See English Sparrow.

Tri-color. See Red-headed Woodpecker.

Turnstone, Calicoback, or Brant Bird.-Length, nine and a half inches; extent, nineteen inches; bill, one inch long; head, white, the crown streaked with black; sides and front of the neck, black; chin and throat, white; 
back and upper part of wings, rusty brown, with broad black bands; sides of the breast, white, the upper part reaching around on sides of neck, black; belly and rump, white; tail, white, with black band at the end tipped with white; wings, brown and black and edged with white and with white bar. In winter there is less brown in the plumage and the blask feathers on the head, neck and breast have white edges.

The nest is a mere depression in the ground lined with dead leaves. The eggs are four in number, very variable in color, from a pale green to a cream, spotted with gray, black and brown, and one and two-thirds by one and onesixth inches in size.

The birds breed in the far north and spend the winter in South America. They are numerous along the New Jersey coast in May and again from August 1 to September 15. They are generally seen in small companies or singly and never in large flocks.

They feed on the spawn of the king-crab or horse-shoe crab and also on insects and small shellfish; they obtain the latter frequently by turning over stones, using both bill and breast for that purpose.

\section{Tyrant Flycatcher. See Kingbird.}

reery. Seé Wilson's Thrush.

Vireo, Blue-headed, or Solitary Vireo.-Length, five and three-fifths inches; bill, one-fourth of an inch, white eye-ring; top and sides of head, bluish gray, shading gradually into olive green on the back; breast and belly, white; sides, white, with greenish yellow tinge; tail, dusky; wings, dusky, some of the long feathers edged with white and with white tips on the smaller feathers, forming two bars across the wing. The head of the female is not so bright.

The nest, a pocket-like contrivance, hanging from the forked branch of a tree, is composed of tendrils, plant 
down and pine needles, finely interwoven. The eggs are three or four in number, white, with brown and black spots, principally near the large end, and four-fifths by oue-half an inch in size.

The birds breed chiefly north of the United States and southward along the higher mountains; they spend the winter in eastern Mexico and southward. In New Jersey they appear in migrations, from April 20 to May 5 and again from September 20 to October 15.

Their song is varied, of tender cadence, pitched in a higher key than the rest of the Vireos, but rather shrill.

The food of the birds consists of insects.

Vireo, Red-eyed.-Length, six and one-fourth inches; bill, two-fifths of an inch, dusky above, light below; crown of head, slaty gray, with a black and a white line passing over each eye; eye, red; back, tail and wings, olive green; breast, belly and sides, white, the latter slightly washed with olive; feet, lead-colored.

The nest very much resembles that of the preceding species, but the Red eyed Vireo is especially fond of thick white cobwebs such as cover the eggs of some spiders in his architecture. The eggs are three or four in number, white, with black and brown spots, principally near the large end, and eight-ninths by one-half an inch in size.

The birds breed in eastern North America northward to Hudson's Bay and spend the winter in Mexico and southward. In New Jersey they are plentiful in summer, arriving about the end of April and leaving about October 10.

Wilson Flagg refer's to him as a preacher and says that he repeats moderately, with a pause between each sentence, You see it? - you know it? - do you hear me?-do you believe it? "All these strains are delivered with a rising inflection at the close, and with a pause, as if waiting for an answer."

The food of the birds consists of insects. 
V^ireo, Solikary. See Blue-headed Vireo.

Vireo, W'arbling.-Length, five and four-fifths inches; bill, three-tenths of an inch; head and neck, ash; dusky line over eye; back, tail and wings, gray olive green, the wings with darker edges; breast, belly and sides, white, with distinct yellow tinge, deeper on the sides.

The nest is the same as that of the Blue-headed Vireo. The eggs are three or four in number, white, with black and brown spots, principally near the large end, and four-fifths by three-fifths of an inch in size.

The birds breed from eastern North America to Hudson's Bay and spend the winter in eastern Mexico.

Their song is a pleasant warble from a tree top, occasionally marred by a few scolding notes. Wilson Flagg compares the song to brig-a-dier, brig-a-dier, brig-a-dier, brigate.

The food of the birds consists of insects.

Wireo, W'hite-eyed.-Length, five and one-fourth inches; bill, three-tenths of an inch, dark lead colored; eye, white; yellow eye-ring and spot before the eye; throat, white; head and back, olive green; belly, white, with a strong tint of yellow on the sides; tail, olive green, with grayish tinge; wings, olive green with grayish tinge, yellowish white tips forming double wing bar; feet, dark lead.

The nest is similar in construction to that of the Blueheaded Vireo, but is built near the ground, generally in a bush, and contains a good deal of green moss in its makeup. The eggs are either three or four in number, white, with black and brown specks more plentiful near the large end, and three-fourths by one-half an inch in size.

The birds breed throughout the eastern United States and spend the winter in eastern Mexico and southward. They are to be found during the summer all over New 
Jersey, but are especially numerous in the pine barren swamps in the southern part of the state.

The White-eyed Vireo is the Mockingbird of his kind, his song being an imitation of the notes of all the others, intermixed with a great deal of scolding. He scolds whenever any danger threatens or he is disturbed and when nothing troubles him he scolds himself.

The food of the bird consists of insects.

rireo, rellow-throated.-Length, six inches; bill, one-third of an inch in length; white eye-ring; throat, bright yellow; cheeks, yellow; head and back, bright olive green; breast, bright yellow; belly, white; rump, gray; tail, grayish brown, edged with white; wings, grayish brown, tipped with white, forming double wing bar, some of the feathers edged with white.

The nest is very similar in construction to that of the other Vireos, but is generally covered with yellowish or gray lichens on the outside. The eggs are either three or four in number, white, with brown and black spots more plentiful near the large end, and four-fifths by three-fifths of an inch in size.

The birds breed from the Middle States north and spend the winter in Mexico and southward. They are comparatively scarce in New Jersey during the summer, appearing about May 2 and leaving about the middle of September.

The song of the birds, frequently delivered while on the wing, is, however, generally heard from the tree tops; its intonation is rather harsh and like most of its tribe, it seems fond of scolding.

The food of the birds consists of insects.

\section{Wirginia Nightingale. See Cardinal-bird.}

Vulture, Turkey.-Length, two and a half feet; extent, six feet, two inches; bill, two and one-fourth inches; 
head and neck, naked; wrinkled skin of the head and neck, reddish; the plumage is a brownish black.

The birds nest on the ground or among the debris of rotten logs or stumps, almost invariably in swamps. The eggs are from one to three in number, of a dirty white, with brown and purple blotches principally near the large end, and two and three-fourths by two inches in size.

The birds breed and are distributed throughout the southern Middle States southward, a small number also wintering regularly in the southern part of New Jersey.

Their cry is a low hissing sound.

Their food is exclusively carrion and they never feed on live animals or vegetalle matter.

Wrarbler, Bay-breasted.-Length, five and twothirds inches; extent, twelve inches; bill, one-third of an inch; forehead, cheeks and sides of head, black; a buff patch on eacb side of the neck; crown, bright chestnut; throat, light chestnut, extending down the whole side of the body; back, gray, with black streaks; lower breast and belly, buffy white; tail, forked, brownish black with white spots; wings, brownish. black, with two white bars; legs and feet, dark ash. In the female the colors are duller. In fall the bird is quite different, being olive above, streaked with black, the under parts are yellowish white and the breast and sides have a chestnut tinge. At this season the Bay-breasted and Black-poll Warblers are very similar to one another.

The birds nest in trees, generally in evergreens; the nest is made of grass and tendrils, lined with hair and plant down. The eggs are either four or five in number, rough on the surface, white, with light markings of brown, and three-fourths by one-half inch in size.

They breed from northern New England to Hudson's Bay and spend the winter in Eastern Mexico, and southward to Colombia. They are regular migrants in New Jersey, but generally scarce, although in some years more 
abundant; they are more numerous in the fall than in the spring; they occur in New Jersey from May 10 to May 20 and again from September 10 to October 1.

Their song, according to Mr. Langille, is "a very soft warble, somewhat resembling the syllables tse-chee, tsechee, tse-chee, tse-chee, but far too liquid to admit of exact spelling."

Their food is composed of insects and larvae, which they gather from the branches of trees.

\section{Warbler, Black and White, or Black and White} Creeper.-Length; five and one-fourth inches; extent, seven and one-fourth inches; bill, one-third of an inch, black, slightly curved; crown, black, with a white stripe in the center and another behind the eye; throat and breast, streaked with black and white; cheeks, black; back, black and white streaked; belly, white in the middle, black stripes on sides; tail, black, white on outer quills; wings, black, with two white bars and some white edging; legs and feet, dusky; claws, very sharp.

The nest is generally well hidden, on the ground, adjoining rock, log or stump; it is made of bark and grasses, lined with fine tendrils and hair. The eggs are either four or five in number, white, with brown spots, the latter generally forming a wreath near the large end, and two-thirds by one-half an inch in size.

The birds breed in eastern North America as far north as Hudson's Bay and spend the winter in the Gulf States and the West Indies as far southward as South America. In New Jersey they are common, especially in the southern part, but mo:e numerous during migrations; they occur in migrations from April 25 to May 15 and again from August 10 to October 5.

Their song is thin and wiry, very seldom heard and somewhat resembles tschwee-tschwee-tschwee.

The food of the birds consists of insects and larvae, 
generally gathered from tree trunks and the under sides of branches and twigs.

Warbler, Black and Yellow. See Magnolia Warbler.

Warbler, Blackburnian, or Torch Bird.Length, five and one-fourth inches; extent, nine inches; bill, one-third of an inch, brown; head, the crown is black, with an orange spot in the centre and a yellow stripe passing in a line over the eye; throat and fore breast, fiery orange; back, black, streaked with white; belly and sides, white, tinted with yellow and streaked with black; tail, slightly forked, black, the inner vanes white, except at the tip; wings, black, with large white patch; legs, brown; feet, dusky. In the female the upper parts are olive, streaked with black, and the orange color is duller. In the fall plumage the orange is replaced by pale yellow, while the upper parts are like the female.

The nest is well hidden in trees, generally evergreens, and is made of twigs and grasses, lined with tendrils and finer grasses. The eggs generally number four, although as many as six have been found; they are grayish or bluish white, with spots and blotches of brown, and twothirds by one-half an inch in size.

The birds breed from northern New England northward and southward on the Alleghanies and spend the winter in the Bahamas and northern South America. They are common in New Jersey during migrations, occurring from May 5 to May 15 and again from September 15 to October 1.

Their song is a warble with very little variety, sounding something like wee-see, wee-see, wee-seek, occasionally with a tsee-tsee-tsee.

Their food is composed of insects and larvae, generally gathered from the higher branches of trees. 
Warbler, Black-capped. See Wilson's Warbler.

Warbler, Black-poll.-Length, five and a half inches; extent, eight and a half inches; bill, one-third of an inch, the upper half black and the lower yellow, with bristles at the base; crown and hind head, black; cheeks, white; back, olive gray, with black streaks; breast, white, with black streaks on the sides, rump, ashy; tail, black, with white spots on the outer feathers; wings, black, edged with ash and crossed by two white bars; legs and feet, reddish yellow. In the female the upper parts are an olive green with black streaks; under parts, white with a yellow tinge; sides of throat, neck and body, with black streaks. Fall plumage of the male similar to the spring female.

The nest is large, considering the size of the bird, and is built in evergreens, spruce preferred. It is made of twigs, moss and lichens, lined with grass and fine roots. The eggs are either four or five in number, white, with brown spots, and seven-tenths by one-half an inch in size.

The birds breed from northern New England to Alaska and spend the winter in the Bahamas and northern South America. In New Jersey they are abundant in migrations, occurring from May 10 to June 1 and again from September 20 to October 15.

Their song is very wiry, and still soft, sounding like tree-tree-tree rapidly repeated.

Their food consists of insects, generally taken on the wing.

Warbler, Black-throated Blue.-Length, five and one-fourth inches; extent, eight inches; bill, one-third of an inch, black, with bristies at the base; throat and sides of head, black, the black extending down the sides of the body; back, grayish blue, spotted with black in some specimens; breast and belly, white; tail, dusky black, with white spots and edged with blue; wings, dusky 
black, with a large white spot on the middle, and edged with blue; legs and feet, dirty yellow. In the female the upper parts are an olive green, the white wing patch is very small and the under parts are a soiled yellow.

The nest is built close to the ground, in thick brush in dense woods or swamps; it is made of bark, grasses and pine needles and is lined with fine roots. The eggs are from three to five in number, of a soiled white, with brown spots, and two-thirds by one-half an inch in size.

The birds breed from northern New England northward and spend the winter in Florida and southward. In New Jersey they are very common during migrations, occurring from May 5 to May 20 and again from September 10 to October 10.

Their song is a zwee-zwee-zwee, their call note $z$-ip z-ip. Their food is composed of insects, generally taken on the wing.

Warbler, mlack-throated Green.-Length, five and one-tenth inches; extent, eight inches; bill, one-fourth of an inch, black; cheeks, bright yellow; line over eye, bright yellow; chin, throat and fore breast, black, continued in a stripe down the sides; back, olive green, in some specimens spotted with black; belly, white, in some specimens tinged with yellow; tail, dusky black, edged with ash, the two outer feathers largely white, the next with a white spot; wings, dusky black, with two white wing bars; legs and feet, brownish yellow. In the female the black on the throat and on the breast is mixed with yel. low, and some fall birds have the black markings but dimly outlined.

The nest, built in evergreen trees, over fifteen feet from the ground, is made of twigs and moss, lined with fine roots and grasses. The eggs are four in number, white, with brown spots, and two-thirds by one-half an inch in size.

The birds breed in northern New York and in New 
England and northward and in the higher Alleghanies, and spend the winter in the West Indies and southward. They are common migrants in New Jersey, occurring from May 2 to May 15 and again from September 1 to October 10.

Their song, generally heard from the tops of trees, is likened by Mabel Osgood Wright to an interrogative Willyou-co-me, will-you-co-me, will-you?

Their food consists of insects.

W arbler, Blue-winged.-Length, four and threefourths inches; extent, seven inches; bill, one-third of an inch, bluish black above, lighter below; crown, bright yellow, a black line through the eye; back and rump, bright olive green; breast, belly and sides, bright yellow; tail and wings, bluish gray, the wings with two wing bars, which in some specimens are tinged with yellow. In the female the under parts are less bright and the yellow on the head is confined to the forehead.

The nest is built on the ground or in a tussock or bunch of grass, of bark and leaves, lined with finer grasses and tendrils. The eggs are from four to six in number, white, with light brown spots, and two-thirds by one-half an inch in size.

The birds breed in the eastern United States southward of middle New Jersey, and spend the winter in eastern Mexico and Guatemala. In New Jersey they are abundant during migrations, appearing between April 25 and May 5, all leaving about the first of September.

Their song, according to Mr. Chapman, is a swee-chee, the former inhaled, the latter exhaled.

The birds feed on insects, generally gathered from branches of trees in thick woods or in undergrowth, although they also visit gardens, orchards and willow trees.

Warbler, Camadian.-Length, five and two thirds inches; extent, eight and a half inches; bill, one-third of 
an inch, black, with bristles at the base; crown, spotted with black on blue-gray ground; a line from the bill to the eye, bright yellow; sides of the neck, black; back, bluegray; breast, belly and sides yellow, with a string of longitudinal streaks across the breast; tail, gray, whitish underneath; wings, gray; feet, flesh colored. The female has no black on the head or the sides and the necklace on the breast instead of black is dusky.

The nest is built in mossy banks or under and between roots of trees; it is made of bark, twigs and pieces of wood wrapped in leaves and woven with grasses. The eggs are either four or five in number, white, with brown spots more numerous near the large end, and two-thirds by half an inch in size.

The birds breed in northern New Yolk and New England and northward, southward along the Alleghanies. They spend the winter in Eastern Mexico and southward. In New Jersey they are very common migrants, occurring between May 10 and May 20 and again from August 20 to October 1.

Mr. Nehrling says that their song is "a fine sibilant chirp, reminding one of a Canary's song, but broken and incomplete, and $\mathrm{Mr}$. Thompson writes it rup-it-che, rupit-che, rup-it-chitt-it-lit.

The food of the bird consists of insects.

W*arbler, Chestmat-sided.-Length, five and oneeighth inches; extent, eight inches; bill, one-third of an inch, dusky; crown, bright yellow; a black line behind the eye and a black spot in front of it reaching to the side of the throat; throat, white; back, gray, streaked with black and with a dark greenish margin; rump, olive; breast and belly, white; sides, chestnut, coming downwards from the side of the throat along the neck and reaching to the flanks; wings, black, with yellowish white wing bars; legs and feet, ash. The female is duller in color. The fall dress presents a far different appearance, being a yellow- 
ish olive green on the upper parts and only showing a trace of chestnut on the sides.

The nest is built in bushes, of bark and the stems of leaves, lined with tendrils and fine roots. The eggs are either four or five in number, white, with numerous brown spots, generally forming a wreath near the large end, and seven-tenths by one-half an inch in size.

The birds breed in the eastern United States and Canada and spend the winter in the Bahamas and eastern Mexico as far southward as Panama. They breed in the mountains in New Jersey and are very plentiful in migrations, occurring from May 5 to May 15 and again from September 10 to September 25.

Their note is a feeble chirp or twitter.

They feed on insects, generally gathering them from opening buds and leaves, although they also take earthworms and ants and occasionally a few seeds.

Warbler, Connecticut.-Length, five and two-fifths inches; extent, eight inches; bill, one-third of an inch, the upper part brown and the lower whitish; head and neck, bluish gray; white eye-ring; back, olive green; breast, bluish gray; belly, yellow; sides, tinged with olive green; tail, olive green; wings, olive green; legs, pale flesh color. In the female and young of the year the upper parts are all an olive green and the breast is a pale brown.

The nest is made of grass on the ground. The number of the eggs is four, white, with few brown spots, and three-fourths by three-fifths of an inch in size.

The birds breed in Manitoba and spend the winter in northern South America. In New Jersey they are occasionally seen in weedy fields near the edge of woodlands between September 14 and October 2, but are very rare in spring.

Their song resembles the teacher-teacher of the Orenbird. 
W'arbler, Colden-winged.-Length, five and onefifth inches; extent, eight inches; bill, one-third of an inch; crown, bright yellow; white line over the eye; black patch about the eye and one on the throat, separated by a white stripe; back, bluish gray; lower breast, white; belly, white; sides, gray; tail, bluish gray, with white spots; wings, bluish gray, with large yellow patch. In the female the yellow on the crown is less bright and the patch on the sides of the head and throat is gray.

The nest is built on the ground or near it, of bark and leaves, lined with finer bark and tendrils, interwoven with leaves. The eggs are from four to six in number, white, with brown spots, and two-thirds by one-half an inch in size.

The birds breed throughout Eastern North America north of middle New Jersey and a few summer in the northern part; they spend the winter in Cuba, eastern Mexico southward to Colombia. They are more numerous in New Jersey during the spring migrations, from May 12 to May 16 , but are not a common species.

Their song resembles that of the Blue-winged Warbler, but the notes are more drawn out and of equal length.

Their food is composed of insects.

Wrarbler, Hooded.-Length, five and two-thirds inches; extent, eight and a half inches; bill, one-third of an inch, bristles at the base; forehead and cheeks, bright yellow; crown, black, hood-shaped, connecting with the breast which, together with the throat, is also black; back, bright olive green; breast and belly, rich yellow; tail, olive green with white spots on the outer feathers; wings, olive green. The female is somewhat duller in coloration and has a smaller black hood or none at all.

The nest is built in damp woods, in the crotch of a bush or sapling, of skeleton leaves, bark and roots, lined with fine grasses. The eggs are four or five in number, 
white or cream, with small brown spots, in some forming a wreath near the large end.

The birds breed in the southeastern United States, northward as far as southern New England and are common summer residents in the cedar swamps in the southern part of this state. They spend the winter in Mexico and Panama.

Their song is variable, yet tuneful and sweet and their call note, very frequently uttered, a cheep.

Their food consists of insects.

Warbler, Kentucky.--Length, five and two-fifths inches; extent, eight inches; bill, one-third of an inch; yellow line from back of the eye to the bill; crown and sides of throat, black, the hind liead spotted with blue gray; back, olive green; breast, belly and sides, rich brilliant yellow; tail and wings, rich olive green; legs, pale flesh color. The female is but slightly duller in color.

The nest is large, considering the size of the bird, built on the ground or in a tuft of rank grass. It is made of twigs and loots, wrapped with leaves and lined with small. roots and hair. The eggs are four or five in number, white or soiled white, with large brown spots, and threefourths by three-fifths of an inch in size.

The birds breed in the Eastern United States, rarely farther north than New Jersey and seem to be scarce in the southern part of the state. They spend the winter in Cuba, eastern Mexico and southward to Panama.

The song, in which it indulges frequently and at great length, is loud and delivered in threes, tweedle-tweedletweedle.

Their food consists of insects.

\section{Warbler, Magnolia, or Black and rellow} Warbler.-Length, five and one-eighth inches; extent, seven and a half inches; bill, one-third of an inch, dark; crown, bluish gray; forehead and cheeks, black; a white 
line behind the eye; throat, yellow; back, black, with olive green margin; rump, yellow; breast, rich yellow, with large black stripes which extend down the sides; belly, rich yellow; tail, slightly forked, jet black; with white patches near the middle; wings, dark, with large white patch; legs, brown; feet, dark. In the female the back is dark green and the cast of the plumage is duller. Both male and female are brighter in spring than in fall, and the young birds have the throat grayish and the black streaks confined to the flanks.

The nest is built in an evergreen tree, of twigs and skeleton leaves, lined with fine roots. The eggs are from three to five in number, white, with brown spots, the latter forming a wreath near the large end, and twothirds by one-half an inch in size.

The birds breed in northern New England as far north as Hudson's Bay and spend the winter in the Bahamas, Cuba and Central America. In New Jersey they are common in migrations, occurring from May 10 to May 20 and again from September 10 to September 20.

Mr. Langille describes their song as "a loud, clear whistle, which may be imitated by the syllables chee-to, chee-to, chee-tee-ee, uttered rapidly and ending on the falling inflection."

The food of the birds is composed of insects.

\section{Warbler, Alyrtle, or Yellow-rumped Warbler.}

Length, five and two-thirds inches; extent, eight inches; bill, three-tenths of an inch, black; head, bluish gray or slate color, with yellow patch on the crowin; throat, white; back, slate color, streaked with black; rump, yellow; breast, white, streaked heavily with black, with a yellow patch on each side; belly, white; sides, white, streaked with black; tail, slate color, with white spots; wings, slate color, with two white bars; feet, black. In the female there is less black below and the upper parts have a distinctively brownish tinge, while the yellow 
markings are obscure. The fall plumage of the male is similar.

The nests are built in evergreen trees, of leaf skeletons and tendrils, lined with grass. The eggs are four or five in number, white or soiled white, with brown spots, and seven-tenths by one-half an inch in size.

The birds breed mainly north of the United States and many spend the winter as far south as Panama, being distributed throughout the southern Middle States at this season. Although a number winter in New Jersey they are more numerous here during migrations, from April 25 to November 1.

Their note is a mere chirp.

Their food is composed of insects, but in the fall and winter they also eat quantities of bay berries and the berries of the poison sumach.

W'arbler, Nrashoille-Length, four and threefourths inches; extent, seven inches; bill, one-fourth of an inch, dusky, tapering to a fine point; top and sides of head, slate color; a small chestnut spot on the crown; back, rich olive green; breast and belly, bright yellow, whitish posteriorly; tail, slightly forked, dark olive, broadly edged with olive green; wings, brownish, edged with olive green; legs, ash; feet, dirty yellow.

The nest is built on the ground of pine needles and grasses, lined with finer grasses and moss. The eggs are four or five in number, white, thickly dotted with brown, and three-fifths by one-half an inch in size.

The birds breed in Canada as far north as Hudson's Bay and spend the winter in eastern Mexico and southward to Guatemala. In New Jersey they are regular during migrations, occurring between May 6 and May 15 and again between September 15 and October 1.

Wilson says that their " notes very much resemble the breaking of small twigs, or the striking of small pebbles of different sizes smartly against each other for six or 
seven times, and loud enough to be heard at a distance of thirty or forty yards. It was some time before I could ascertain whether the song proceeded from a bird or an insect."

The food of the birds consists of insects.

Warbler, Palm.-Length, five and one-fourth. inches; extent, eight inches and over; bill, five-eighths of an inch; crown, chestnut brown, with a yellow streak over each eye; back, duller brown, faintly streaked with dusky; wings and tail, brown, the latter with white spots on the outer feathers; under surface, yellow, with chestnut streaks on the sides of the neck and breast; duller in fall.

There are two varieties of this bird, the eastern one being more properly called the Yellow Palm Warbler. The Western Palrn Warbler differs in having the under surface buffy white, the yellow showing only on the feathers under the tail.

Both birds occur in New Jersey during migrations, but the former is much the more plentiful. The birds breed far northward and winter in the Southern States and Mexico.

The birds differ from all the other small Warblers in their habit of wagging the tail up and down like the Titlark and Water Thrush.

\section{Warbler, Parula, or Blue Tellow-backed W'ar-} bler.-Length, four and three-fourths inches; extent, six and a half inches; bill, one-third of an inch, black above, flesh-color below; head, blue; a small touch of white above and below the eye; throat, yellow; back, blue, with a triangular or crescent-shaped greenish yellow patch in the middle; breast, yellow, with brownish or chestnut band across it, which is generally dusky in the middle; belly, white; tail, dark slate, with two white spots; wings, dark slate, edged with blue and with two white bars; legs 
and feet dark brown. In the female the breast band is frequently absent.

The nest is a delicate contrivance hung from a slender branch, made of filmy moss of the kind known as Spanish or beard moss. The eggs number cither four or five, white, with brown spots more numerous near the large end, two-thirds by one-half an inch in size.

The birds breed in the eastern United States and Canada and spend the winter in southern Florida and southward. They breed in large numbers in the middle and southern part of New Jersey, especially in the cedar swamps. Migrants occur from April 30 to May 20 and again from September 10 to October 1.

$\mathrm{Mr}$. Nehring describes their notes as shrill and wiry, somewhat resembling chirr-irr-irr-eeh.

The food of the birds consists of insects and caterpillars, generally gathered in the tops of trees from young leaves and blossoms.

Warbler, Pine. - Length, five and a half inches; extent, nine inches; bill, one third of an inch; yellow eyeline; throat, yellow; back, olive green; breast and belly, yellow, suffused with olive on the sides, the lower part of the belly white; tail, forked, olive green, with white spots on the outer feathers; wings, olive green, with two dull white bars. In the female the upper parts have a brownish cast, the under parts are a dirty white and the breast is tinged with yellow. Young birds show scarcely a trace of yellow.

The nest is found in evergreen trees, the bird rarely leaving pines or hemlocks for breeding; it is built of bark, leaves and tendrils. The eggs are four or five in number, white or soiled white, with numerous brown spots, generally forming a wreath near the large end, and seventenths by one-half an inch in size.

The birds breed in the eastern United States from the Southern States to Ontario and New Brunswick and spend 
the winter in the Southern States and as far south as the Bahamas. They are very common throughout the pine barrens of New Jersey during the summer, arriving as early as March 30.

Minot describes their song as a "delicately trilled whistle," and Wilson says that it is a "simple rerterated chirrup continued for four or five seconds."

The food of the bird consists of the seeds of the pine and of insects; the latter it generally takes while moving along the trunks or limbs of trees Creeper-fashion, although it also pursues them into the air or to the ground.

W-arbler, Prairie.-Length, four and three-fourths inches; extent, six and a half inches; bill, one-fourth of an inch; sides of neck, black; yellow line over eye and a short one below it; back, olive green, spotted with chestnut; breast and belly, bright yellow; sides, bright yellow, streaked with black; tail, olive green, with large white spots on the outer feathers; wings, olive green, with two yellow wing bars. The female has little or no brown on the back.

The nest is an exquisite piece of workmanship and very light. It hangs from a branch in a bush or thicket and is made of fine shreds of plant fibre, bark and fine tendrils; it is lined with small roots and hair. The eggs are either four or five in number, white, with numerous brown spots, forming a wreath near the large end, and two-thirds by one-half an inch in size.

The birds breed in the eastern United States as far north as southern New England and spend the winter in southern Florida and the West Indies. They are very plentiful throughout the summer in the pine barrens in New Jersey; migrants occur from May 10 to May 15 and again from September 1 to September 15.

The song of the bird is quaint and curious, consisting 
of wee repeated three times and followed by zee repeated six or seven times.

The food of the birds consists of small caterpillars and winged insects.

Warbler, Wilson's.-Length, five inches; bill, onefourth of an inch, bristles at the base; forehead, yellow; crown, glossy black, the upper parts olive green and the lower, yellow. The female lacks the black cap. The bird builds a nest on the ground, of leaves and grass, lined with finer grasses and hair; the eggs are four or five in number, white, with brown spots, and three-fifths by oue-half an inch in size. It breeds mostly north of the United States and spends the winter in eastern Mexico and Panama. It is not very common in New Jersey, occurring during migrations only, between May 12 and May 20 and again belween August 26 and October 10. Its food is composed of insects, generally taken on the wing.

Warbler, Worm-eating.-Length, five and a half inches; extent, eight inches; bill, two-fifths of an inch, black above, flesh-colored below; crown, black, with a central buff stripe and another over the eye; line behind the eye, black; back, olive green; breast, belly and sides, buff, paler on the belly and throat; tail, olive green; wings, olive green, edged with dusky brown; legs and feet, pale clay.

The nest of the bird is built on the ground of roots, leaves and bark. The eggs are four to six in number, white, with brown spots, and two-thirds by one-half an inch in size.

The birds breed in the eastern United States, but not abundantly further north than the middle of New Jersey, and spend the winter in Cuba, southern Mexico and Panama. They arrive in New Jersey about May 7 and leave about September 1 , 
Their song resembles that of the Chipping Sparrow, but is weaker.

The food consists of insects, principally spiders and caterpillars.

Warbler, Yellow, or Summer Yellow-bird.Length, five and one-tenth inches; extent, seven inches; bill, one-third of an inch, lead-colored; head, bright yellow; back, rich greenish yellow; breast, belly and sides, rich yellow, streaked with reddish brown; tail, slightly forked, dark slate, with yellow spots; wings, rich greenish yellow, edged with lighter yellow; legs, pale clay; feet, light brown. The female is greener on the back, the wings are dark slate and there is little or no brown on the breast and sides.

The bird builds its nest in shrubs or in trees, fruittrees preferred; the nest is made of large quantities of plant down, with grasses and hair. The eggs are either four or five in number, bluish white, with numerous brown spots, the latter frequently forming a wreath near the large end, and seven-tenths by one-half an inch in size.

The birds breed throughout eastern and northern America and spend the winter in Mexico and northern South America. They arrive in New Jersey about May 1 and leave about the first of. September.

The song of the bird resembles the syllables sweet-sweetsweet-sweeter.

The food of the birds consists of insects.

Warbler, Y'ellow-backed Blue. See Parula Warbler.

Warbler, Yellow Red-Poll. See Palm Warbler.

Warbler, Yellow-Rumped. See Myrtle Warbler.

Water Thrush.--Length, six inches; extent, nine and a half inches; bill, one-third of an inch, dark brown; 
head, dark brown; a yellowish line over the eye; back, dark brown; throat, breast, belly and sides, white, with a pale yellow tinge, streaked and spotted with black; tail and wings, dark brown; legs, flesh colored; feet, dark.

The nests are built in the most inaccessible places in swamps, in mossy banks or under the roots of fallen trees; they are made of moss, lined with skeleton leaves and fine roots. The eggs are either four or five in number, white or cream, with brown spots, most numerous near the large end, and three-fourths by three-fifths of an inch in size.

The birds breed in the northern United States and northward and spend the winter in the Gulf States and the West Indies and southward to northern South America. In New Jersey they are transient, but frequently occur in considerable numbers between May 5 and 20 and August 3 to September 1.

The song is frequently described as resembling the running water and purling brooks near which it is fond of living. Wilson says: "They are eminently distinguished by the loudness, sweetness and vivacity of their notes, which begin very high and clear, falling with an almost imperceptible gradation till they are scarcely articulated."

The food of the bird consists principally of aquatic insects. It lives much on the ground, walking along with a continual wagging of the tail up and down in the manner of a Sandpiper.

Water Thrush, Louisiana.-This bird is very similar to the foregoing, being only about a quarter of an inch longer; it has a white line over the eye, and the throat and middle of the belly are not streaked or spotted with black, while the lower parts lack the yellow tinge of the preceding.

The bird breeds in the eastern United States not northward of the Delaware and Hudson valleys and is very scarce in this state. It spends the winter in the gulf 
states, the West Indies and southward to Central America.

Of its song Mr. Frank M. Chapman (Handbook of Birds of Eastern North America, Appleton \& Co.) says: "As a songster the Water Thrush is without a rival. His song is not to be compared with the clear-voiced carol of the Rose-breasted Grosbeak, the plaintive chant of the Field Sparrow, or the hymnlike melody of the true Thrushes; it is of a different kind. It is the untamable spirit of the bird rendered in music. There is an almost fierce wildness in its ringing notes. On rare occasions he is inspired to voice his passion in a flight-song, which so far exceeds his usual performance that even the memory of it is thrilling."

Water Wagtail.--See Water Thrush.

wrater W•itch. See Pied-billed Grebe.

W hip-poor-will.-Length, nine and a half inches; extent, nineteen inches; bill, one-third of an inch, dusky, bent a little at the point, bristles at the base very long, exceeding the tip of the bill by three-quarters of an inch. The plumage above is variegated with black, pale cream, brown and rust color, sprinkled and powdered with minute streaks and spots; the upper part of the head is a light brownish gray, marked with a central streak of black with others radiating from it; the tail is rounded, black, irregularly barred and mottled with whitish gray or cream; the three outer ones with the terminal third white in the male; the wings are dark brown, barred on the outer webs with rusty; a narrow semi-circle of white passes across the throat; the breast and belly are irregularly mottled and streaked with black and yellow ochre; the legs and feet are of a light flesh-color, seamed with white. The female is about an inch less in length, and the bar across the throat is a brownish ochre; the cheeks are a brighter brownish orange and the streak over the eye is lighter. 
The birds make no attempt whatever to build a nest, the eggs being placed on the ground or in some leaves, but always in a dry place. The eggs are two in number, white, with lilac markings and gray spots, and one and one-fifth by four-fifths of an inch in size.

The birds breed from the plains to the sea coast and from Virginia to Nova Scotia and spend the winter in the Gulf states, Mexico and Guatemala. They arrive in New Jersey about the middle of April and leave about the first of October.

Their cry is whip-poor-will, generally repeated five times and in the evening, frequently far into the night; when near the bird an introductory cluck may be heard between the notes.

The food of the birds consists of insects, generally caught on the wing.

It is often confused with the Night Hawk, but is quite distinct, being recognized by its brown and buff coloration, instead of black and white and by the long bristles at the base of the bill, which are wanting in the Night Hawk.

W'histler. See American Golden-eye.

Wridgeon.-Length, from nineteen to twenty-two inches; extent, from twenty-six to thirty inches; bill, one and two-fifths inches, slate colored; the crown is white or buff in the middle, the sides being a glossy green, sprinkled with black; cheeks and throat, yellowish white, with fine black bars; back, grayish brown, with narrow wavy black bars; belly, white; sides, very light bay, with narrow wavy black lines; tail, pointed, brownish ash; wings, brownish ash, with white patch near the shoulder and a large glossy green spot. The eggs number from seven to twelve, are of a cream color, and two by one and a half inches in size. The birds breed north of the United States and spend the winter in Cuba and Guatemala. They occur in New Jersey from the latter part of October 
to November 15. They are very fond of wild celery and when feeding on this are considered an excellent bird for the table.

Willet.-Length, sixteen inches; extent, thirty-three inches; bill, two and one seventh iuches, black; head, neck and back, pale gray brown, spotted with biack; breast, white, barred with dark brown; rump, grayish brown, some of the feathers edged with gray; sides, white, barred with dark brown; tail, white, with brownish black bars; wings, grayish brown, with white bar and tipped with white; legs, blue; feet, blue, half-webbed. In winter the birds are half gray above and the lower parts are pure white. The female is a little larger than the male.

The nest is a depression in the ground or sand, generally near the sea shore, and lined with rushes and coarse grasses. The eggs are generally four in number, greenish white or brown, spotted with brown or purple, and two by one and a half inches in size, very thick near the large end.

The birds breed throughout temperate North America to New England and Nova Scotia and spend the winter in the West Indies and South America. Formerly they were very plentiful in New Jersey and bred all along the sea coast; a few may still breed in Cape May county, but they are generally seen during migrations, occurring between April 20 and May 15 and again between July 17 and September 15.

Their cry is a sharp pill-will-willet.

Their food is composed of shellfish, marine worms and other aquatic insects.

Woodcock.-Length, male, ten and a half inches; extent, sixteen inches. Female, length, twelve inches; extent, eighteen inches. The bill is of a brownish flesh color, black towards the tip, the upper part ending in a slight knob, and about two and a half inches in length; 
forehead, line over the eye and whole lower parts, reddish tawny; sides of the neck, inclining to ash; between the eye and the bill a streak of dark brown; crown, from the forehead to the eye backwards, black, crossed by three narrow bands of brownish white; cheeks, marked with a bar of black, variegated with light brown; back, deep black, each feather tipped or marbled with light brown, with numerous fine zigzag lines of black crossing the lighter parts; a streak of light gray down each side from the shoulder; tail, black, each feather marked along the outer edge with small spots of pale brown and ending in narrow tips of pale drab color above and silvery white below; lining of the wings, bright rust; legs and feet, pale reddish flesh color. In the female the bill is nearly three inches in length; the black on the back is not quite so intense and the sides under the wings are slightly barred with dusky.

The nests, which are built in April, are rudely constructed of withered grass and leaves; they are located on the gromind and frequently at the root of some old stump. The eggs are either four or five in number, of a dull clay with numerous brown spots, especially near the large end, and some of a very pale purple, an inch and a half by one inch in size, tapering suddenly towards the small end.

The birds breed and are distributed throughout the eastern United States and Canada, but are very rarely seen in New Jersey in the winter months, even in the southern part of the state. They arrive here about the middle of March and leave for further south about the first of November.

Their cry is a quack when rising from the ground, but changing to a murmur as the bird ascends; when on the ground the bird frequently utters a p'tul, p'tul, peent, peent.

The food of the bird consists of aquatic worms and the larvae of insects. 


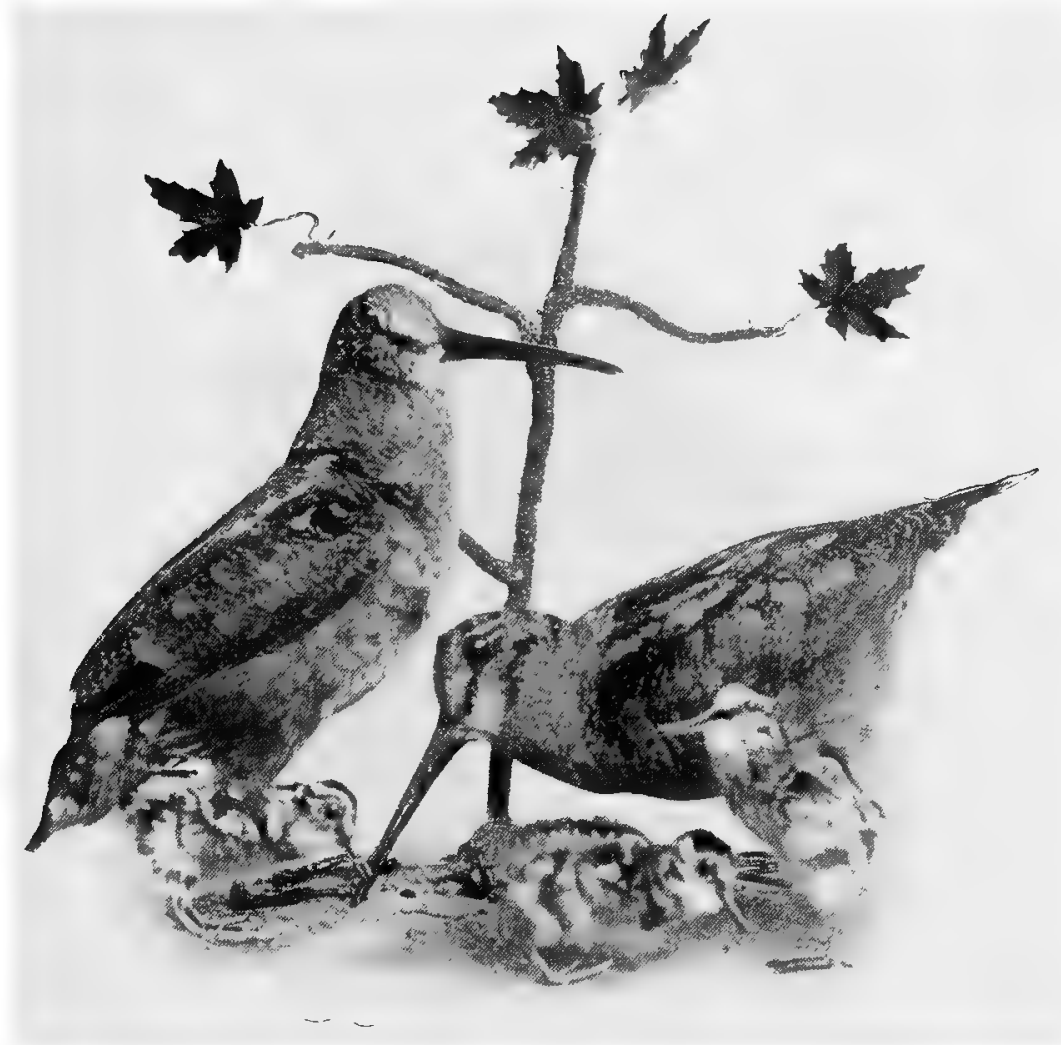

WOODCOCK. 

Woodpecker, Downy.-Length, six and three-quarter inches; extent, twelve inches. It is the smallest, most active and most numerous of Woodpeckers. In plumage it is a miniature of the Hairy Woodpecker, the only difference being that the outer tail feathers are white and barred with black instead of pure white.

The nest is similar to that of the Hairy Woodpecker but smaller, the eggs are from four to six in number, white in color and three-fourths by three-fifths of an inch in diameter.

It breeds and is distributed throughout the whole of eastern North America.

Its cry is a shori, sharp peek, peek, with a rattling cry. Like all Woodpeckers it beats a rattling tattoo.

The food of the bird is composed of insects and vegetable matter. Government reports of analyses of 140 stomachs indicate that the contents were it per cent. insects, 25 vegetable and 1 sand, ants predominating among the insects. The charge that this Woodpecker bores a tree for the purpose of sucking the sap, and thus destroys the vitality of the tree, has been completely disproven, the boring being merely done for the purpose of obtaining insects and larvae.

Woodpecker, Golden- Winged.-See Flicker.

Woodpecker, Hairy.-Length, nine inches; extent, fifteen inches. The crown is black and the line under and over the eye white; the eye is placed in a black line, which widens as it descends to the back; hind head, scarlet, sometimes mixed with black; the nostrils are hidden under long white hairs thrown forward and upwards; the bill is a bluish horn color, grooved, wedged at the end, straight, and about an inch and a quarter long; touches of black, proceeding from the lower part of the bill, end in a broad black stripe that joins the black on the shoulder; the back is black, divided by a broad stripe 
of white, the feathers composing which are somewhat loose and unwebbed, resembling hairs, whence its name; the rump and the shoulders of the wings are black; the wings are black, tipped and spotted with white; the tail consists of ten pointed feathers, the four middle ones black; the next partially white; the two exterior ones white and tinged at the tip with a brownish burnt color; the whole under side is pure white; the legs, feet and claws are light blue, the claws very large and strong. The female wants the red on the hind head.

The nest is built in May in a dead or hollow tree or limb; the bird digs out a hole, cutting directly into the tree some six or eight inches and then obliquely downwards from twelve to twenty inches. The eggs are from four to six in number, of a clear white color, and one by three-fourths of an inch in size.

The birds breed and are distributed throughout the eastern United States as far south as North Carolina.

Their cry is an unbroken tremulous roll, with considerable interval between strokes.

The food of these birds consists principally of insects and larvae; it is an exceedingly useful bird for the destruction of insect life. The mischief it does is twofold, first by eating fruit and secondly by distributing the seeds of sumac, poison ivy and other objectionable plants, these seeds, on account of their hard covering, passing through the alimentary canal of the bird without losing their vitality. Government reports of analyses of 82 stomachs indicated that the contents were 68 per cent. insects, 31 per cent. vegetable and 1 per cent. sand. One-third of the insects were ants and one-third beetles, the latter mostly of the wood-boring kind, together with large quantities of plant lice, caterpillars and similar insects.

Woodpecker, Red-bellied.-Length, nine and a half inches; extent, seventeen inches; bill, one and one-tenth 

inches; top of the head and back of the neck, scarlet; back, transversely barred with black and white; breast and belly, dull ash, with a red tinge in the middle; tail, white and black; wings, black and white in bars and spots. The female has the crown gray and the scarlet is confined to a crescent-like patch on the back of the neck and a little about the nostrils. The birds nest in holes in trees as do the woodpeckers, the eggs being from four to six in number, one inch by three-fourths of an inch in size. It is a resident of the Southern States and occasionally a specimen straggles into New Jersey.

Woodpecker, Red-headed.-Length, nine and threefourths inches; extent, seventeen inches; bill, one and one-fifth inches; whole head, neck, throat and fore breast, crimson red; back, black, with steel-blue gloss; rump, white; lower breast and belly, white, sometimes tinged with red in the middle; tail, black, tipped with white; wings, black, with steel-blue gloss, the eight inner feathers white on their terminal half. The young birds lack all trace of red; above, bluish black, strongly edged with gray; rump. white; below, dull white, mottled with blackish on throat and breast; white portion of wings barred with black. The birds nest in holes in trees, the eggs being from four to six in number, and one inch by threefourths of an inch in size. They breed in the eastern United States but are scarce in New Jersey, seldorn coming east of the Delaware or Hudson rivers.

Woodpecker, Vellon-bellied. See Sapsucker.

Wren, Carolima.-Length, five and a half inches; extent, seven inches; bill, three-fifths of an inch, the upper part bluish black, the lower light blue; a white line over the eye. The upper parts are a bright rusty brown, white, downy spots being concealed in the rump feathers; the wings and tail are barred finely with black; the under 
parts are a light reddish buff, becoming whitish on the throat; the legs and feet are flesh-colored.

The birds nest in holes in stumps and trees or in any convenient crevice about buildings; the nest is very large, considering the size of the bird, and is made of grasses, leaves and feathers, lined with finer grasses and hair. The eggs are from four to six in number, white or cream, with brown spots, the latter frequently forming a wreath near the large end and three-fourths by three-fifths of an inch in size.

The birds remain all the year in southern New Jersey but in the northern part of the state occur only as accidental stragglers.

Their alarm note is a loud chirrup, with the accent on the former syllable, while the song is aptly compared by Wilson to sweet William, sweet William.

The food of the birds is composed of insects and larvae, especially those found in damp places near water.

Wren, House.-Length, four and a half inches; extent, five and three-fourths inches. The whole upper parts are of a deep brown, conspicuously barred with black on the wings and tail and indistinctly on the back; rump, with concealed spots of white; under surface, white, shaded with brown on throat and sides and barred with black on the flanks and under the tail; legs and feet, light clay-colored; bill, black, long, slightly curved, sharppointed.

The birds breed preferably in a bird box, abandoned kitchen or farming utensil, or in any crevice about human habitation; if none such afford it will find a crevice in the woods, an owl's hole, or anything affording shelter. The nest is built during the first part of May and is composed of crooked roots and sticks and is lined with feathers. The eggs are from six to eight in number, of a reddish brown, covered with minute spots of a darker color, sometimes forming a wreath near the large end, and three- 
fifths by one-half an inch in size. There are two broods each season.

The birds are at home all over the United States; they arrive in New Jersey about the first of May and leave shortly after the first of October.

Their song is a sudden, frequently repeated and abruptly ending roulade; the alarm note is chit-chit chitchit.

Government reports show that 98 per cent. of the food is animal matter and 2 per cent. grass, sand and bits of wood; one-half of the animal food is composed of grasshoppers and beetles and the other half of caterpillars, bugs and spiders.

Wren, Long-billed Mrarsh.--Length, five and onefourth inches; extent, seven inches; bill, one-half an inch, dark above, light below; centre of head, brown, blackish on the sides; white line over the eye; back, black, with white streaks; shoulders, brown; breast, white; rump, brown; sides, white, washed with light brown; tail and wings, brown, barred with white and black; feet, brown.

The nest, large for a bird of this size, is spherical in form, resembling a ball fastened to reeds or bushes; the entrance is from the side. It is made of grasses, sedge and reed stalks and lined with finer grasses. The eggs are from five to nine in number, of a light brown, with deeper brown spots, and two-thirds by one-half an inch in size.

The birds breed throughout eastern North America and spend the winter in the Southern States; they are very plentiful in the cattail swamps along the rivers and coast and a few remain all the year in Cape May county. They rarely occur above tide water.

Their song resembles that of the House Wren, but is at times wiry and harsh.

The food of the birds consists of insects, principally those frequenting swamps and river's.

Wren, Short-billed Marsh.-Length, four inches; ex- 
tent, six and a half inches; bill, two-fifths of an inch; the upper parts streaked with white, black and dark yellowish brown; the wings and tail are barred and the under parts are white, with a light buff tinge on the breast, sides and under the tail. The nest in construction is similar to that of the Long-billed Marsh Wren, at times built between reeds, but more frequently found on the ground or in a hummock in marsh. The eggs are from six to eight. in number, white, and two-thirds by one-half an inch in size. The breeding location is similar to that of the Longbilled Marsh Wren, but the birds are scarce in New Jersey; a few winter in the southern part of the state; they may breed occasionally, but they mostly occur during migrations. Their song is a chep-chep-chep-de-de-de-derrrrr.

Wren, Winter.-Length, four inches; extent, five and one half inches; bill, one-third of an inch. The bird is light brown beneath and a dark brown on the upper parts; wings, tail and back, barred with dusky; on the rump there are white spots concealed in the plumage, and the lower breast and the sides of the belly are heavily barred with black; the tail and bill are short. Its short, erect tail and dark color below distinguish it from the House Wren, which it resembles in general coloration.

The nest is built in brush or among the roots of trees, of twigs and moss, lined with feathers and hair. The eggs are from five to seven in number, white or cream, speckled finely with reddish brown, and seven-tenths by one-half an inch in size.

The birds breed from the northern United States north. ward and spend the winter in the Eastern States. In New Jersey they are quite common between September 25 and April 1.

Their song is very strong and musical, but seldom heard in this state. 'The alarm note is a series of sharp cries chick-chick-chick. 
The food of the birds is composed of larvae and insects such as are generally found in watery places, roots of bushes and piles of old timber.

Yellow-bird. See Croldfinch.

Yellow-bird, Summer. See Yellow Warbler.

Yellow-hammer. See Flicker.

Tellow-legs, Areater--Length, fifteen inches; extent, twenty inches; bill, two and one-fifth inches. Upper surface, black; mottled with white, assuming a definite streaked appearance on the head and neck and more spotted on the back and shoulders; rump, white, barred with black; tail, barred black and white; long wing feathers, black; under surface, white, streaked with black on the neck and throat, passing into arrow-shaped marks on the breast and transverse bars under the wings and tail; middle of belly, white; legs and feet, yellow. In winter much grayer above and the markings below indistinct.

The nest is a mere depression in the ground, lined with a little grass. The eggs are four in number, grayish white, with brown and lilac spots more numerous near the large end, and one and seven-tenths by one and threetenths of an inch in size.

The birds breed in the northern part of North America and spend the winter in the south Atlantic states southward as far as South America. They are common in New Jersey during migrations, occurring from April 20 to May 16 and again from July 15 to October 1.

Their food consists of small shellfish, insects and. worms.

Yellow-legs, Summer.-The plumage of this bird resembles that of the Greater Yellowlegs in almost every particular, but it is a considerably smaller bird, being eleven inches in length. Its eggs are one and one-half 
by one and one-sixth inches in size. It breeds in northern North America and spends the summer in the south Atlantic states southward to South America. It is common during migrations on the coast and occasionally found inland, occuring between April 30 and May 10 and again between July 15 and October 10 . When taken along the sea coast its flesh generally has a sedgy flavor, but when taken inland it is esteemed palatable.

Yellow-throat, Maryland.-Length, five and onethird inches; extent, eight and one-half inches; bill, twofifths of an inch; black; a broad black band across the forehead and on the cheeks, bordered with gray above; back, olive green; throat and breast, bright yellow; belly, white; sides, white, with a brown tinge; tail, olive green above, with yellow feathers below; wings, brownish olive; feet, flesh-colored. In the fall the birds are browner above, the belly is a deeper yellow, the sides are a deeper brown and the black mask is scarcely discernible. The female never has black on the forehead or on the cheeks. [For illustration see facing page 28.]

The nest, which is large for a bird of this size, is built on or near the ground, of bark, grasses and leaves, lined with skeleton leaves and small roots. The eggs are from three to five in number, white, with brown spots, more numerous near the large end, and seven-tenths by onehalf an inch in size.

The birds breed in the eastern United States northward to Canada and spend the winter in the south Atlantic states, the West Indies, Mexico and southward to Panama. In New Jersey they are abundaut from April 25 to October 12.

Their song is generally written wichity-wichity-wichitywichity.

The food of the birds is composed of insects. 





